\title{
Revisão de Ceyxia Girault, stat. rev. (Hymenoptera, Chalcididae, Brachymeriini)
}

\author{
Tathiana Viana de Andrade $^{1} \&$ Marcelo Teixeira Tavares ${ }^{1,2}$
}

${ }^{1}$ Universidade Federal do Espírito Santo, Programa de Pós-graduação em Ciências Biológicas (Zoologia), Avenida Marechal Campos 1468, 29043900 Vitória-ES, Brasil. tathianandrade@yahoo.com.br; tavares.mt@gmail.com

${ }^{2}$ Bolsista de Produtividade em Pesquisa do CNPq.

\begin{abstract}
Revision of Ceyxia Girault, stat. rev. (Hymenoptera, Chalcididae, Brachymeriini). The genus Ceyxia Girault has its status revalidated and 27 species are assembled under it. Seven species previously described are diagnosed (or redescribed) and discussed and 20 new species are described. Ceyxia flaviscapus Girault, 1911 and C. ventrispinosa Girault, 1911 stat. rev. were originally combined with Ceyxia and following are new combinations: C. belfragei (Crawford, 1910) comb. nov., stat. rev.; C. concitator (Walker, 1862) comb. nov.; C. decreta (Walker, 1862) comb. nov.; C. dorsalis (Walker, 1861) comb. nov.; and C. villosa (Olivier, 1790) comb. nov. Ceyxia paraguayensis Girault, 1911 is proposed as junior synonymy of Ceyxia flaviscapus Girault, 1911. The new species are: C. acutigaster sp. nov.; C. amazonica sp. nov.; $C$. atuberculata sp. nov.; $C$. bellissima sp. nov.; $C$. dentiformis sp. nov.; $C$. diminuta sp. nov.; C. fusidentata sp. nov.; C. gibbosa sp. nov.; C. laminata sp. nov.; C. laticlipeata sp. nov.; C. latilabra sp. nov.; $C$. longiarticulata sp. nov.; C. longiscutellaris sp. nov.; C. longispina $\mathbf{s p . ~ n o v . ; ~}$ C. nigropetiolata $\mathbf{s p .}$ nov.; $C$. paraensis $\mathbf{s p .}$ nov.; $C$. parvidentata sp. nov.; $C$. perparva sp. nov.; $C$. pseudovillosa $\mathbf{s p}$. nov.; and $C$. tibiodilatata sp. nov. Host relationships of some species of the genus are presented. A key to species of the genus is also included.
\end{abstract}

KEYWORDS. Hosts; parasitoids; taxonomy.

RESUMO. Revisão de Ceyxia Girault, stat. rev. (Hymenoptera, Chalcididae, Brachymeriini). O gênero Ceyxia Girault é revalidado e 27 espécies são combinadas a ele. Sete espécies previamente descritas são diagnosticadas (ou redescritas) e discutidas, e 20 espécies novas são descritas. Ceyxia flaviscapus Girault, 1911 and C. ventrispinosa Girault, 1911 stat. rev. foram originalmente combinadas com Ceyxia e as seguintes são combinações novas: C. belfragei (Crawford, 1910) comb. nov., stat. rev.; C. concitator (Walker, 1862) comb. nov.; C. decreta (Walker, 1862) comb. nov.; C. dorsalis (Walker, 1861) comb. nov.; e C. villosa (Olivier, 1790) comb. nov. Ceyxia paraguayensis Girault, 1911 é consyiderada sinônimo júnior de Ceyxia flaviscapus Girault, 1911. As novas espécies são: C. acutigaster sp. nov.; C. amazonica sp. nov.; $C$. atuberculata sp. nov.; $C$. bellissima sp. nov.; $C$. dentiformis sp. nov.; $C$. diminuta sp. nov.; $C$. fusidentata $\mathbf{s p .}$ nov.; $C$. gibbosa sp. nov.; C. laminata sp. nov.; C. laticlipeata sp. nov.; C. latilabra sp. nov.; C. longiarticulata sp. nov.; C. longiscutellaris sp. nov.; C. longispina sp. nov.; C. nigropetiolata sp. nov.; $C$. paraensis sp. nov.; $C$. parvidentata $\mathbf{s p .}$ nov.; $C$. perparva sp. nov.; $C$. pseudovillosa sp. nov.; e $C$. tibiodilatata sp. nov. Dados sobre a associação com hospedeiros são apresentados para algumas espécies do gênero. Uma chave para as espécies do gênero é incluída.

PALAVRAS-CHAVE. Hospedeiros; parasitóides; taxonomia.

A tribo Brachymeriini reúne Caenobrachymeria Steffan, gênero monotípico, e Brachymeria Westwood, um dos gêneros de Chalcididae com maior riqueza de espécies. As espécies da tribo possuem um processo dentiforme alongado (processo falciforme) presente na garra tarsal posterior que Wijesekara (1997) tratou como sinapomorfia do grupo.

Atualmente são conhecidas mais de 300 espécies válidas de Brachymeria, 62 dessas presentes nas Américas. Poucas revisões da fauna do Novo Mundo foram publicadas até o momento e tratam, ou apenas da fauna neártica (Crawford 1910b; Burks 1936, 1960), ou de parte das espécies neotropicais (Bouček 1992).

Girault (1911) descreveu Ceyxia, combinou a ele quatro espécies do Paraguai, descritas no mesmo artigo, e designou Ceyxia fummipenis como espécie-tipo. Girault (1913) propôs Ceyxia como subgênero de Chalcis Fabricius e Peck (1951) o propôs como sinônimo de Brachymeria Westwood.
Durante o estudo das espécies neotropicais de Brachymeriini, um grupo de espécies foi definido com base em caracteres morfológicos, como: presença de uma carena escrobo-malar na face; mandíbulas tipicamente alongadas e afiladas no ápice; e por estar associado a vespas que habitam ninhos de barro. Este grupo inclui todas as espécies descritas originalmente no gênero Ceyxia, incluindo a espécie tipo, e assim, esse gênero tem aqui seu status revalidado.

\section{MATERIALE MÉTODOS}

Foram examinados 507 exemplares pertencentes às coleções citadas a seguir (os acrônimos seguem, principalmente, Evenhuis 2009): (AMNH) American Museum of Natural History, Nova Iorque, EUA; (BMNH) The Natural History Museum, Londres; Inglaterra (CAS) California Academy of Sciences, São Francisco, EUA; (CNCI) Canadian 
National Collection of Insects, Ottawa, Canadá; (DCBU) Universidade Federal de São Carlos, São Carlos, Brasil; (DZUP) Universidade Federal do Paraná, Curitiba, Brasil; (EMEC) Essig Museum of Entomology, University of California, Berkeley, EUA; (FIOC) Fundação Instituto Oswaldo Cruz, Rio de Janeiro, Brasil; (IBGE) Coleção Zoológica da Reserva Ecológica do IBGE, Brasília, Brasil; (IBSP) Instituto Biológico, São Paulo, Brasil; (IIES) Instituto de Investigaciones Entomologicas, Salta, Argentina; (IMLA) Instituto de Zoologia, Fundación Miguel Lillo, San Miguel de Tucumán, Argentina; (INHS) Illinois Natural History Survey, Champaign, EUA; (INPA) Instituto Nacional de Pesquisas da Amazônia, Manaus, Brasil; (LACM) Los Angeles County Museum, Los Angeles, EUA; (MBML) Museu de Biologia Professor Mello Leitão, Santa Teresa, Brasil; (MCZH) Museum of Comparative Zoology, Cambridge, EUA; (MNRJ) Museu Nacional do Rio de Janeiro, Rio de Janeiro, Brasil; (MPEG) Museu Paraense Emílio Goeldi, Belém, Brasil; (MZSP) Museu de Zoologia da USP, São Paulo, Brasil; (QCAZ) Pontificia Universidad Catolica del Ecuador, Quito, Equador; (SEMC) Snow Entomological Museum, Lawrence, EUA; (UCDC) The Bohart Museum of Entomology, Davis, EUA; (UFES) Universidade Federal do Espírito Santo, Vitória, Brasil; (UFMG) Universidade Federal de Minas Gerais, Departamento de Zoologia, Belo Horizonte, Brasil; (UFRRJ) Universidade Federal Rural do Rio de Janeiro, Seropédica, Brasil; (UFVB) Universidade Federal de Viçosa, Museu de Entomologia, Viçosa, Brasil; (USNM) National Museum of Natural History, Washington, EUA; (ZMHB) Museum für Naturkunde der Humboldt Universität, Berlim, Alemanha.

A terminologia morfológica segue Gibson (1997) e para a escultura do tegumento Harris (1979), exceto os termos umbílico (pequenas fóveas circulares com uma cerda no fundo, típica do dorso da cabeça e mesossoma de muitos Chalcididae) e umbilicado (Bouèek 1988). As medidas foram tomadas de acordo com Delvare (1992). A fórmula mandibular é indicada por 1:1, 2:2 ou 2:3, sendo o primeiro algarismo referente ao número de dentes da mandíbula esquerda e o segundo algarismo ao da direita (Delvare 1992).

Os seguintes acrônimos se referem aos termos morfológicos e medidas: A, altura; C, comprimento; DOA, maior diâmetro do ocelo anterior; EM (espaço malar), distância entre a margem ocular e a margem oral; EPE, largura do espaço parescrobal no nível em que foi tomada a largura do escrobo; ES, comprimento da veia estigmal; ETC (espaço torulus-clipeal), distância entre a margem inferior do soquete antenal e a margem do clípeo; F segmento funicular (exemplo: F1 primeiro, F2 segundo); FO, distância entre os dois ângulos laterais da fossa oral; FV, largura do fronto vértice; $\mathrm{L}$, largura; $\mathrm{LF}$, largura em vista frontal, do olho; LS, maior largura do escrobo; M, comprimento da veia marginal; OOL, menor distância entre o ocelo posterior e o olho adjacente; Ovipositor, comprimento da porção protraída da bainha do ovipositor; PM, comprimento da veia pósmarginal; POL, distância entre os ocelos posteriores; SM, comprimento da veia submarginal; $\mathrm{T}$, tergito do gáster (exemplo:, T1, primeiro: T2 segundo).

No item distribuição geográfica, as regiões (paises ou estados, no caso do Brasil) citadas pela primeira vez para as espécies previamente descritas são marcadas com asterisco $(*)$.

Chave para a identificação dos gêneros de Brachymeriini

1. Dorso do mesossoma com umbílicos no máximo 0,20x o DOA (Fig. 71); metapleura com fóveas rasas e mal definidas (Fig. 72) ............. Caenobrachymeria Steffan

Fronte, vértice e dorso do mesossoma com umbílicos no mínimo $0,25 x$ o DOA (Figs. 5, 8, 16); metapleura com fóveas bem definidas

..2

2(1). Face inferior com carena escrobo-malar, que se estende da porção ínfero-lateral da margem escrobal em direção à carena malar (Figs. 10, 15, 16, 24, 30, 46, 70); mandíbulas 1:1 (Figs. 18, 43) ou 2:2 (Figs. 10, 13, 15, 20), neste caso, dente superior no máximo $0,5 \mathrm{x}$ tão longo quanto o inferior; carena occipital com porção superior convergindo para o forâmen occipital (Figs. 44) ..........

Ceyxia Girault

Face inferior sem carena escrobo-malar, se carena ou ruga presente junto a porção ínfero-posterior da margem escrobal, esta é recurvada para a órbita ocular; mandíbulas $2: 2$ ou $2: 3$, se $2: 2$, dente inferior nunca distintamente mais longo que o superior; carena occipital com porção superior direcionada para o ocelo posterior...... Brachymeria Westwood

\section{Ceyxia Girault, stat. rev.}

Ceyxia Girault 1911: 382. (Espécie-tipo Ceyxia fumipennis Girault, designação original).

Chalcis Fabricius: Girault 1913: 67 (Ceyxia considerado sinônimo júnior e subgênero de Chalcis).

Brachymeria Westwood: Peck 1951: 586 (Ceyxia considerado sinônimo júnior de Brachymeria).

Redescrição. Cabeça e dorso do mesossoma com umbílicos no mínimo 0,25x DOA; antena com 13 segmentos, 1 anellus, 7 funiculares e 3 clavais; carenas interocelar e pré-orbital ausentes, a pós-orbital presente; projeção interantenal presente, eventualmente reduzida e indicada por área pilosa entre os tórulos; face inferior com carena escrobo-malar que se estende da porção ínfero-lateral da margem do escrobo em direção à carena malar (Figs. 10, 15, 16, 24, 30, 46, 70); EPE distintamente menor que $0,5 \mathrm{x}$ LS; ruga escrobo-clipeal raramente presente; margem inferior do escrobo distintamente acima do nível ocular inferior; mandíbula alongada e com o ápice afilado, às vezes 1:1 (Figs. 18, 43), se 2:2 (Figs. 10,13, 15, 20), dente superior no máximo $0,5 x$ tão longo quanto o inferior, normalmente, afastado do ápice e diminuto ou vestigial; carena occipital com porção superior convergindo em direção ao forâmen occipital (Fig. 44); carena frenal presente; espiráculo propodeal com a margem anterior projetada posteriormente $\mathrm{e}$ recobrindo, ao menos em parte, a abertura do mesmo (Figs. 19, 23); metasterno com duas carenas submedianas; metacoxa sem 
tubérculo ventral; segmentos funiculares dos machos, eventualmente, com pilosidade ventral mais longa e densa.

Distribuição. Predominantemente neotropical, ocorrendo do sul dos Estados Unidos ao sul do Brasil e Norte da Argentina.

Hospedeiros. Várias espécies estudadas emergiram de ninhos de barro construídos por vespas aculeadas. Algumas espécies de Ceyxia stat. rev. estão associadas a espécies de Trypoxylon (Crabronidae, Trypoxylonini) e atuam como parasitóides desses (Peruquetti \& Del Lama 2003, como Brachymeria sp). Peruquetti (2001) confirmou que C. villosa comb. nov. atua como parasitóide primário de Trypoxylon albitarse (Fab.). Exemplares aqui estudados foram obtidos, segundo dados de etiquetas, de ninhos de Sceliphron $s p$ (Sphecidae), de "eumenídeo" e de Auplopus femoratus (F.) (Pompilidae). Segundo Fritz \& Genise (1980), algumas espécies de Trypoxylon se utilizam de ninhos abandonados de outros himenópteros, assim, dados referentes à associação com outros aculeados, que não Trypoxylon, necessitam ser confirmados.

Comentários. As espécies desse gênero podem ser facilmente identificadas pela presença da carena escrobo-malar (Figs. 10, 13, 20, 24, 26, 30, 46, 70), carena occipital convergindo para o forâmen occipital (Fig. 44), e margens dos espiráculos propodeais projetadas sobre as aberturas dos mesmos (Figs. 19, 23). A carena escrobo-malar é distinta daquela que está presente em parte das espécies do subgênero Pseudobrachymeria, que é recurvada em direção à margem ocular. Na maioria das espécies as mandíbulas são caracteristicamente afiladas e pontiagudas no ápice. Peruquetti (2001) afirmou que fêmeas de C. villosa comb. nov. utilizam suas mandíbulas, que são bantante afiladas e ponteagudas, para desgastar os ninhos de barro de T. albitarse permitindo, assim, a oviposição. A presença desse tipo de mandíbula em outras espécies do gênero e a constatação que outras espécies estão associadas a ninhos de barro, sugere que o esse uso das mandíbulas pode ser comum entre as espécies. Desta mesma forma estas mandíbulas também devem ser de grande importância para os adultos emergirem dos ninhos de barro.

Chave para identificação das espécies de Ceyxia Girault, stat. rev.

1. Mandíbulas com dois dentes apicais, nitidamente bidentada (Fig. 20) . .2

Mandíbulas com um dente (Figs. 18, 24, 43) ou com o dente superior reduzido e afasta do ápice (Figs. 10, $13,15,26,46)$ 3

2(1). Projeção interantenal indicada por uma carena curta e pilosa; OOL maior ou igual ao DOA; carena frenal trapezoidal com margem posterior reta ou ligeiramente ondulada; espinho apical da metatíbia distinto, ápice agudo (como Fig. 29); gáster no mínimo 1,5x mais longo que o mesossoma C. decreta comb. nov.
Projeção interantenal laminar, usualmente com um tubérculo apical (Fig. 20); OOL menor que DOA; carena frenal bilobada ou emarginada (Figs. 22, 23); metatíbia com espinho apical indistinto, ápice rômbico (Fig. 21); gáster no máximo 1,2x mais longo que o mesossoma C. flaviscapus

3(1). Mesonoto e escutelo castanhos ou avermelhados ..... 4 Mesossoma todo negro ……………………………....... 8

4(3). Escutelo deprimido, quase plano, geralmente com interstício da área central maior que o diâmetro dos umbílicos (Fig. 19); carena frenal arredondada; carena epicnemial não projetada ou emarginada na porção mediano-ventral C. dorsalis comb. nov.

Escutelo nitidamente convexo, interstício menor que o diâmetro dos umbílicos; carena frenal bilobada ou suavemente emarginada (Figs. 11, 31); carena epicnemial proeminente e emarginada na porção mediano-ventral

5

5(4). Projeção interantenal indicada por uma carena pilosa (Fig. 10) 6

Projeção interantenal indicada por uma saliência pilosa da superfície do escrobo (Figs. 54, 50) 7

6(5). Ocelo anterior afastado da margem do escrobo por $0,5 \mathrm{x}$ o seu próprio diâmetro (Fig. 10); face inferior com rugas escrobo-clipeais ........... C. belfragei comb. nov.

Ocelo anterior afastado da margem do escrobo por, no mínimo, seu próprio diâmetro (Fig. 30); face inferior sem rugas escrobo-clipeais

C. nigropetiolata $\mathbf{s p . ~ n o v . ~}$

7(5). Escutelo giboso; metafêmur com nove dentes ventrais (Fig. 57); espinho apical da metatíbia curvo e agudo (Fig. 57); bainha do ovipositor com ápice truncado (Fig. 56) C. gibbosa sp. nov.

Escutelo convexo; metafêmur com cinco a sete dentes, os dois últimos fundidos em uma lâmina (Fig. 53); espinho apical da metatíbia robusto e rômbico (Fig. 53); bainha do ovipositor com ápice acuminado (Fig. 52) C. fusidentata $\mathbf{s p . ~ n o v . ~}$

8(3). Carena da margem do escrobo não se estende sobre a área parescrobal (Fig.16); lateral do pronoto sem rugas delimitando a margem superior do sulco transversal

Carena da margem do escrobo se estende sobre a paraescrobal (Fig. 8); lateral do pronoto com rugas delimitando a margem superior do sulco transversal (Fig. 9) .. 12

9(8). Carena transversal acima da depressão foraminal ausente; metafêmur com três dentes ventrais, o distal o maior (Fig. 65); escutelo com margem posterior 
bilobada (Fig. 64) ............... C. longiscutellaris sp. nov.

Carena transversal acima da depressão foraminal presente; metafêmur com seis a sete dentes ventrais; escutelo com margem posterior arredondada; somente carena frenal bilobada

10(9).F1 2,5x mais longo que largo (Fig. 61); F3-F5 no mínimo $1,3 \mathrm{x}$ mais longos que largos

C. longiarticulata $\mathbf{s p . ~ n o v . ~}$

F1 no máximo 1,4x mais longo que largo; F3-F5 no máximo tão longos quanto largos .. 11

11(10). Projeção interantenal indicada por uma carena curta e pilosa (Fig. 26); F2-F3 no mínimo 0,8x tão longos quanto largo (Fig. 27); segundo ao quarto metatarsômeros mais longos que largos; cerdas da margem dorsal da metatíbia mais curtas que a metade da largura mediana da tíbia (Fig. 29)

C. longispina sp. nov.

Projeção interantenal geralmente laminar (Fig. 58); F2F3 0,6x tão longos quanto largos; segundo ao quarto metatarsômeros mais largos que longos; cerdas da margem dorsal da metatíbia tão longas quanto a largura mediana da tíbia C. laminata sp. nov.

12(8). Carena da margem do escrobo com porção que se estende sobre a área parescrobal recurvada em direção aos olhos (Fig. 15)

13

Carena da margem do escrobo com porção que se estende sobre a área parescrobal paralela a margem dos olhos (Fig. 8) .. 14

13(12). Projeção interantenal laminar (Fig. 5); asa anterior sem linha de cerdas subcubital abaixo da dobra cubital ..... C. amazonica sp. nov.

Projeção interantenal dentiforme (Fig. 15); asa anterior com linha de cerdas cubital completa

C. dentiformis sp. nov.

14(12). Projeção interantenal laminar, usualmente com um tubérculo apical (como na Fig. 20) .. 15

Projeção interantenal indicada por uma carena curta e pilosa (Fig. 8) .... 16

15(14). Mandíbulas com dois dentes apicais desenvolvidos; metatíbia com ápice rômbico e espinho apical indistinto (Fig. 21); carena da margem do escrobo não se estendendo sobre a porção superior da área parescrobal .......................................... C. flaviscapus

Mandíbulas com dente superior vestigial e afastado do ápice; metatíbia com espinho apical distinto (Fig. 42); carena da margem do escrobo se estendendo sobre porção superior da área parescrobal

C. ventrispinosa

16(14). Carena da margem do escrobo se estendendo sobre a porção superior da área parescrobal (Fig. 8)

C. atuberculata $\mathbf{s p . ~ n o v . ~}$

Carena da margem do escrobo não se estendende sobre a porção superior da área parescrobal 17

17(16).Metafêmur estreitado na base (Fig. 69); metatíbia distintamente alargada no ápice e comprimida lateralmente (Fig. 69) C. tibiodilatata $\mathbf{s p . ~ n o v . ~}$

Metafêmur e metatíbia não como acima 18

18(17). Projeção interantenal indicada por uma saliência pilosa da superfície do escrobo (Figs. 50, 54) .. 19

Projeção interantenal indicada por uma carena ou lâmina . .21

19(18). Carena frenal arredondada; carena escrobo-malar inconspícua próximo a carena malar; face ventral da metacoxa, metafêmur e metatíbia marrom-claros ou amarelos C. latilabra sp. nov.

Carena frenal bilobada ou suavemente emarginada; carena escrobo-malar uniforme em toda sua extensão; metacoxa; maior parte do metafêmur e metatíbia negros

20(19). Mandíbulas unidentadas (Fig. 24); carena frenal bilobada; dobra basal indicada por três fileiras de cerdas; área frenal lisa ou inconspicuamente esculturada C. laticlipeata sp. nov.

Mandíbulas com dente superior presente, reduzido ou vestigial; carena frenal suavemente emarginada (Fig. 35); dobra basal indicada por fileira de cerdas; área frenal coriácea, crenulada na metade posterior .....

. C. perparva $\mathbf{s p . ~ n o v . ~}$

21(18). Ocelo anterior atinge a margem do escrobo (Fig. 26)

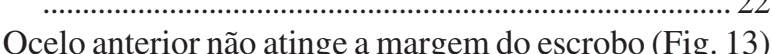

Ocelo anterior não atinge a margem do escrobo (Fig. 13)

22(21). Projeção interantenal formada por uma lâmina espessa (Fig. 43); escapo não atinge a margem do ocelo anterior C. villosa comb. nov.

Projeção interantenal indicada por uma carena curta e pilosa (Fig. 37); escapo atinge a margem do ocelo anterior .23

23(22). Com carena longitudinal acima do occipício (Fig. 38); escutelo convexo, completamente umbilicado; carena frenal bilobada; aréola mediana do propódeo sem divisão; antena com clava afilada no ápice

C. pseudovillosa sp. nov.

Sem carena longitudinal acima do occipício; escutelo plano, com área central sem umbílicos (Fig. 66); carena frenal suavemente emarginada; aréola mediana do propódeo dividida longitudinalmente (Fig. 66); antena alargada no ápice C. paraensis sp. nov. 
24(21). Mandíbulas unidentadas; T7+T8 1,3x mais longo que largo (Fig. 3) C. acutigaster $\mathbf{s p . ~ n o v . ~}$

Mandíbulas bidentadas com dente superior vestigial e afastado do ápice (Fig. 8); T7+T8 tão longo quanto largo .

25

25(24). Escutelo plano, com área central sem umbílicos; espinho da metatíbia rômbico 26

Escutelo convexo, completamente pontuado; espinho da metatíbia agudo

26(25). Mandíbula com dente inferior afilado (Fig. 16); escrobo com margem carenada até $0,75 x$ de sua altura; escutelo com interstício coriáceo; célula basal glabra; corpo com pilosidade do branca ........... C. diminuta sp. nov.

Mandíbula com dente inferior arredondado no ápice (Fig. 46); escrobo completamente carenado (Fig. 47); escutelo com interstício liso (Fig. 48); célula basal com uma a quatro cerdas; corpo com pilosidade densa e dourada (Fig. 49) C. bellissima $\mathbf{s p . ~ n o v . ~}$

27(25). Escrobo com margem carenada até $0,8 \mathrm{x}$ de sua altura (Fig. 13); escapo não atinge a margem do ocelo anterior; carena frenal normalmente desenvolvida e acentudamente emarginada (Fig. 14); célula basal com uma ou duas cerdas; metafêmur com sete a oito dentes na margem inferior C. concitator comb. nov.

Escrobo com margem carenada até $0,75 \mathrm{x}$ de sua altura; escapo atinge a margem do ocelo anterior; carena frenal suavemente emarginada; célula basal glabra; metafêmur com cinco dentes na margem inferior ........ C. parvidentata $\mathbf{s p . n o v}$.

\section{Ceyxia acutigaster sp. nov.}

(Figs. 1-4)

Diagnose. Projeção interantenal forma uma carena curta e pilosa na porção anterior (Fig. 1); mandíbula unidentada; metafêmur estriado na porção inferior apical; asas esfumaçadas; gáster acuminado (Fig. 4), T7+T8 1,3x mais longo que largo; bainha do ovipositor longa. $\mathrm{mm})$.

Descrição. Fêmea. Comprimento: 6,8-8,5 mm (Holótipo: 7,2

Coloração. Negra, exceto: ocelo e olho castanhos; perna anterior e média, tégula, face ventral da metacoxa, margem superior da face externa do metafêmur, metatíbia e escapo amarelo; asa esfumaçada; pilosidade branca.

Cabeça. Pilosidade tão longa quanto 2x o tamanho dos umbílicos, mais esparsa e fina ao redor dos ocelos e mais densa na face, têmporas e genas. Umbílicos da porção anterior do vértice com cerca de $0,25 x$ o DOA, na porção posterior do vértice umbílicos irregulares; interstício coriáceo. Face inferior com pontuação irregular, interstício coriáceo. Vértice com perfil arredondado. Face com perfil convexo. Ocelo anterior não toca a margem do escrobo; este com margem carenada até $0,75 x$ de sua altura; superfície interna lisa. Projeção interantenal como uma carena curta e pilosa (Fig. 1). Mandíbula unidentada. Carena pós-orbital encontra a carena genal acima do nível ocular inferior. Carena escrobo-malar incompleta. Escapo não ultrapassa a margem do ocelo anterior. Medidas relativas: cabeça C:A:L 30:50:80; FV 40; LS 25; EPE 5; ETC 10; EM 10; FO 25; DOA 8; APL 5; OOL 5; POL 10; olho A:L:LF 44:32:25; antena: anellus C 2; escapo C: L 25:7; pedicelo 5:5; F1 9:8; F2 8:8; F3-F7 8:9; clava 13:9.

Mesossoma. Dorso convexo, pilosidade cerca de $2 \mathrm{x}$ o diâmetro dos umbílicos, no escutelo mais que $2 \mathrm{x}$ este diâmetro. Umbílicos do pronoto, margem anterior do lobo mediano do mesoscuto e escápula com $0,25 x$ o DOA; no restante do lobo mediano e escutelo cerca de $0,5 \mathrm{x}$ o DOA interstício coriáceo. Carena pronotal ausente na porção mediano-dorsal por $0,5 \mathrm{x}$ o FV. Umbílicos da margem posterior do pronoto irregulares, suas margens anteriores formam uma carena anterior evidente. Porção superior da lateral do pronoto coriácea; sulco transversal inconspícuo e interrompido por uma carena mediana oblíqua. Escutelo convexo; carena frenal bilobada. Área frenal coriácea sem carenas transversais. Mesepisterno com interstício liso. Carena epicnemial bilobada na porção mediano-ventral. Depressão femoral com uma série de carenas transversais incompletas e inconspícuas acima da transepimeral. Epímero superior rugoso. Propódeo areoladorugoso com aréola mediana pentagonal. Asa anterior com dobra basal indicada por duas fileiras de cerdas; dobra cubital com uma fileira de cerdas; linha de cerdas subcubital presente abaixo da cubital. Metafêmur com dez a onze dentes ventrais pequenos, o basal maior (Fig. 3). Metatíbia com espinho apical curto, agudo e levemente curvo (Fig. 3). Medidas relativas: mesossoma C:L 95:70; mesoscuto C 60; escutelo 75:87; asa 180:70; SM 73; M 40; PM 10; ES 5; metacoxa C 45; metafêmur: C:L 72:45.

Metassoma. Pecíolo visível dorsalmente; T1 liso, com pouca pilosidade látero-dorsal e margem posterior dorsal reta, T2-T5 coriáceos com pilosidade látero-dorsal e margem posterior levemente côncava; T6-T7 coriáceos com pilosidade látero-dorsal e margem posterior convexa; hipopígio com margem posterior levemente emarginada. Ápice acuminado. Medidas relativas: gáster C:L 165:55 (+ ovipositor 40); T1 C 50; T7+T8 40:30.

Etimologia. Epíteto específico em referência ao gáster acuminado.

Variações. A metacoxa pode apresentar coloração amarela ou completamente negra. O metafêmur pode apresentar coloração mais intensa na face externa. A carena frenal pode ser mais estreita ou larga.

Distribuição. Panamá, Peru e Brasil (AM, PA, AC, RO, RJ, SP).

Hospedeiros. Um dos exemplares apresenta a etiqueta "parasita de ninhos", sem especificação de hospedeiro. 
Comentários. Esta espécie se diferencia das outras espécies do gênero por apresentar T7+T8 1,3x mais longo que largo (Fig. 4), metafêmur estriado na porção inferior apical e bainha do ovipositor longa. É semelhante à espécie $C$. laticlipeata sp. nov. em relação à mandíbula unidentada e carena frenal bilobada, mas pode ser diferenciada desta por apresentar projeção interantenal formando uma carena curta e pilosa (Fig. 1) e o F1 ligeiramente mais longo que largo (Fig. 2).

Material examinado. Holótipo fêmea, com as etiquetas 'Brasil, AM[azonas] Manaus C[ampus] Univ[ersitário] 21-28.VIII.1988 M. C. Castilho \& J. Elias Bindá, col.' 'armadilha de Shannon' (INPA). Parátipos. PANAMÁ, Zona do Canal: 1 fêmea , Rio Água Salud, 6.V.1913 (J. Zetek) (USMN). PERU, Madre de Dios: 1 fêmea, Tambopata, $15 \mathrm{~km}$ NE Puerto Maldonado, 200m, 18.VI.1989, "ex. bulress of tree" (J. Ashe, R. Leschen) (SEMC). BRASIL, Amazonas: 2 fêmeas, Manaus, Campus Universitário, VI.1982, arm. Malaise (J. A. Rafael) (INPA); 1 fêmea, ibidem, sem data (INPA); 1 fêmea, Manaus, Campus Universitário, 11-19.VIII.1988, arm. Shannon (M. C. Castilho \& J. Elias Binda) (INPA); 1 fêmea, ibidem, 19-26.VIII.1988 (INPA); 1 fêmea, Manaus, Reserva Ducke, 22.IX.1988, arm. suspensa 15 m (J.A.Rafael) (INPA); 1 fêmea, Marãe, Rio Japurá, Maguari, 7 11.X.1988, arm. Suspensa 20 m (J. Dias) (INPA); Pará: 1 fêmea, Serra Norte, Canga, 31.X.-3.XII.1985, arm. Suspensa 1,6 m (J. Dias) (MPEG); 1 fêmea, Santarém, Curuá-Uma, 1.XII.1997, arm. Malaise (A. R. Lisboa) (DCBU); Acre: 1 fêmea, Rio Branco 25.X-8.XI.1991, arm. suspensa 1,6 m (F. Ramos, A. Henriques, I. Gorayeb \& N. Bittencourt) (MPEG); Rondônia: 1 fêmea, Ji-Paraná, 10.VIII.1984 (J. B. Neto) (MPEG); Rio de Janeiro: 1 fêmea, Represa rio Grande, VIII.1972 (Alvarenga); São Paulo: 2 fêmeas, Sorocaba, parasitas de ninho 820 (H. V. Ihering) (MZSP).

\section{Ceyxia amazonica sp. nov.} (Figs. 5-7)

Diagnose. Margem superior do escrobo estreitada no ápice, carena da margem do escrobo recurvada sobre o espaço paraescrobal em direção ao olho (Fig. 5); carena frenal fortemente bilobada (Fig. 6); dente basal do metafêmur agudo; espinho apical da metatíbia presente, triangular, agudo e gáster acuminado (Fig. 7).

\section{Descrição. Fêmea. Comprimento: 8,5-9,1 mm (Holótipo: 9,1} $\mathrm{mm})$.

Coloração. Negra, exceto: olho e ocelo castanhos; metade basal do escapo, tégula, tíbia, metade apical do pró-fêmur e mesofêmur, mancha apical e basal do metafêmur amarelos; asa esfumaçada; pilosidade branca.

Cabeça. Pilosidade tão longa quanto $2 \mathrm{x}$ o diâmetro dos umbílicos, mais esparsa ao redor dos ocelos e mais densa nas têmporas e gena. Umbílicos da fronte e porção anterior do vértice com cerca de $0,25 \mathrm{x}$ o DOA, na porção posterior do vértice umbílicos irregulares; interstício coriáceo. Face inferior com pontuação irregular, interstício coriáceo. Vértice com perfil arredondado. Face com perfil convexo. Ocelo anterior não toca a margem do escrobo; que se estende por sobre a área parescrobal em direção ao olho (Fig. 5), superfície interna lisa. Projeção interantenal laminar. Mandíbula bidentada, dente superior vestigial. Carena pós-orbital encontra a carena genal pouco acima do nível ocular inferior. Carena escrobo-malar conspícua e completa. Antena afilada no ápice; escapo não ultrapassa a margem do ocelo anterior. Medidas relativas: cabeça C:A:L 45:50:105; FV 48; LS 35; EPE 8; ETC 8; EM 15; FO 40; DOA 10; APL 10; OOL 7; POL 18; olho A:L:LF 50:38:28; antena anellus C 2; escapo C:L 30:10; pedicelo C:L 5:5; F1 12:8, F2-F3 10:10; F4 10:11; F5 9:10; F6 10:10; F7 8:10; clava 17:10.

Mesossoma. Dorso convexo, pilosidade cerca de 1,5x o diâmetro dos umbílicos. Pontuação umbilicada do pronoto, margem anterior do lobo mediano do mesoscuto e escápula com 0,3 x o DOA; no restante do lobo mediano cerca de $0,4 \mathrm{x}$ o DOA e no escutelo atingindo $0,6 \mathrm{x}$ o DOA interstício coriáceo. Carena pronotal ausente na porção mediano-dorsal por $0,6 \mathrm{x}$ do FV. Umbílicos da margem posterior do pronoto irregulares, suas margens anteriores formam uma carena anterior evidente. Porção superior da lateral do pronoto coriácea, sulco transversal conspícuo com rugas que delimitam a margem superior. Escutelo convexo; carena frenal bilobada e refletida para cima (Fig. 6). Área frenal coriácea com três carenas transversais. Mesepisterno com interstício liso. Carena epicnemial côncava na porção mediano-ventral. Depressão femoral com carenas inconspícuas e incompletas acima da transepimeral. Epímero superior liso. Propódeo areolado com aréola mediana pentagonal. Asa anterior com a dobra basal indicada por duas fileiras de cerdas; dobra cubital indicada por uma fileira de cerdas; célula basal glabra, linha de cerdas subcubital ausente abaixo da dobra cubital. Metafêmur com nove a dez dentes ventrais, o basal agudo e desenvolvido. Ápice da metatíbia triangular e agudo. Medidas relativas: mesossoma C:L 135:95; mesoscuto C 85; escutelo 105:110; asa 220:75; SM 90; M 50; PM 10; ES 5; metacoxa C 60; metafêmur: C:L90:50.

Metassoma. Pecíolo visível dorsalmente; T1 liso com algumas cerdas nas laterais e margem posterior dorsal reta; T2-T5 lisos com pilosidade látero-dorsal e margem posterior levemente côncava; T6-T7 coriáceos com pontuação umbilicada rasa e margem posterior convexa; hipopígio com lobo mediano proeminente e ápice reto; bainha do ovipositor chanfrada. Ápice acuminado (Fig. 7). Medidas relativas: gáster C:L 185:85 (+ ovipositor15); T1 C 65; T7+T8 20:7.

Macho. Semelhante à fêmea exceto por apresentar o ápice do gáster truncado.

Etimologia. Epíteto específico em referência à distribuição da espécie.

Variações. A projeção interantenal pode ser laminar ou formar uma carena curta e pilosa; a porção mediano-ventral da carena epicnemial pode ser fortemente bilobada ou côncava.

Hospedeiros. Desconhecidos.

Comentários. C. amazonica sp. nov. é semelhante a $C$. ventrispinosa apresentando carena marginal do escrobo que se estende por sobre a área parescrobal (Fig. 5), mas se diferencia de $C$. ventrispinosa por apresentar projeção sem tubérculo apical, asa mais clara, espinho da metatíbia triangular e dente basal do metafêmur mais agudo. 

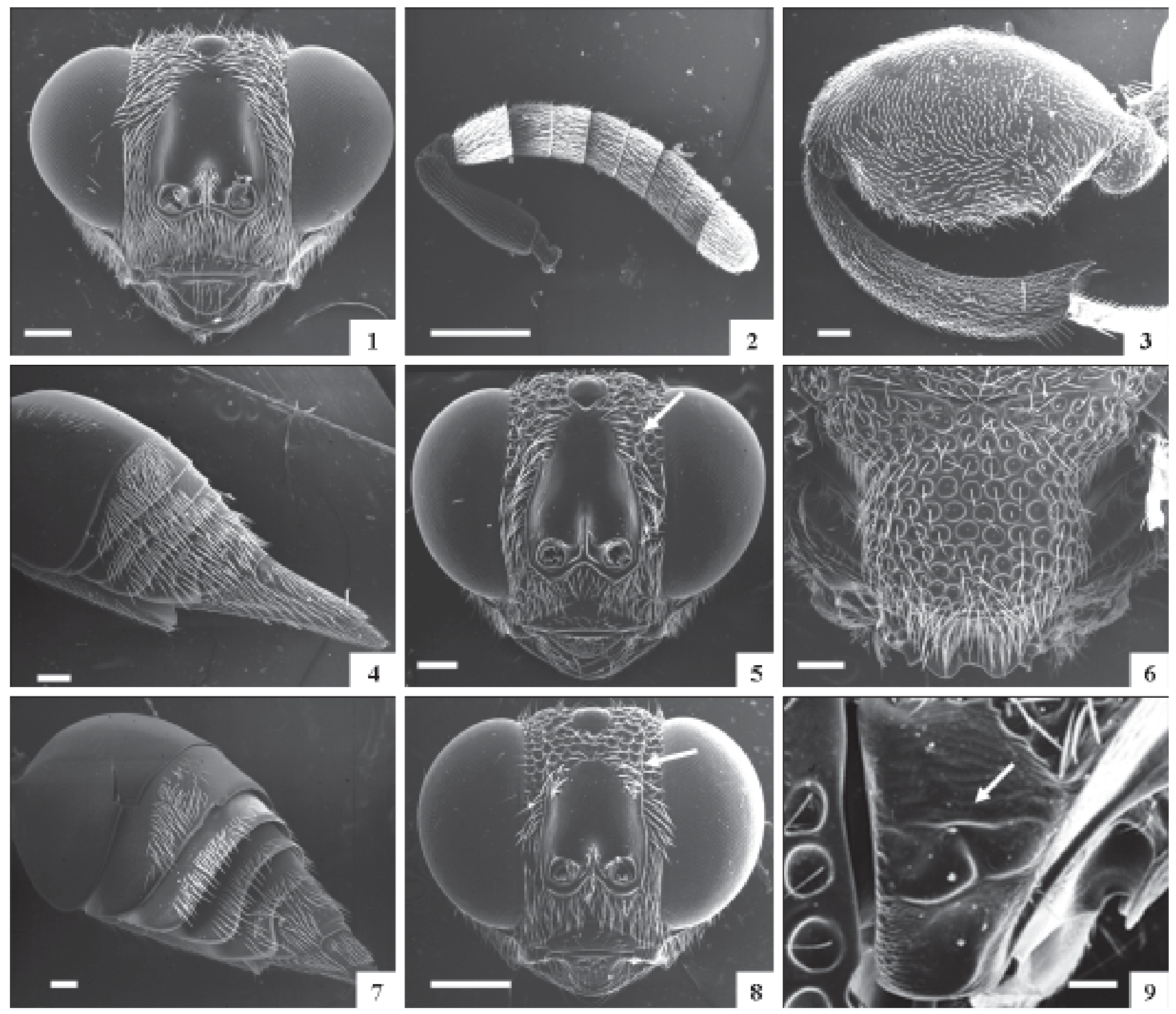

Figs. 1-9. 1-4. Ceyxia acutigaster sp. nov., fêmea: 1, cabeça frontal; 2, antena; 3, metafêmur e metatíbia; 4, metassoma lateral. 5-7. Ceyxia amazonica sp. nov., fêmea: 5, cabeça frontal, indicando carena que se estende sobre o espaço paraescrobal; 6, escutelo dorsal; 7, metassoma lateral. 8-9. Ceyxia atuberculata sp. nov., fêmea: 8, cabeça frontal, indicando carena que se estende sobre o espaço paraescrobal; 9, lateral do pronoto, indicando a ruga que delimita a margem superior do sulco transversal do pronoto. Escala $250 \mu \mathrm{m}$.

Distribuição. Equador, Brasil (AM e MG) e Bolívia.

Material examinado. Holótipo fêmea, com a etiqueta 'BRA[SIL]AMA[ZONAS]- Manaus Campus UFAM 09.XII.1978 Arm. Malaise J.A.Rafael, col. (INPA). Parátipos. EQUADOR, Sucumbios: 1 fêmea, R. Napo, Sacha Lodge, 12-22.II.1994 (Peter Hibbs) (QCAZ); 1 fêmea, ibidem, 22.II-4.III.1994 (QCAZ); 1 fêmea, ibidem, 14-24.III.1994 (QCAZ); Napo: 1 fêmea, Coca, III.1985 (G. Onore) (QCAZ); 1 fêmea, Coca, III.1986 (G. Onore) (QCAZ); 1 fêmea, Coca, IV.1986 (G. Onore) (QCAZ). BRASIL, Amapá: 1 fêmea, Serra do navio, 06.VII.1961 (J. \& B.Bechyné) (MPEG); Amazonas: 1 fêmea, mesmos dados que holótipo, 21.X.1978 (INPA); 1 fêmea, ibidem, 30.XII.1978 (INPA); 1 fêmea, ibidem, 28.VII.1979 (INPA); 1 fêmea, ibidem, 11.VIII.1979 (INPA); 1 fêmea, ibidem, 23.IX.1979 (INPA); 1 fêmea, ibidem, 11.VI.1982 (INPA). Pará: 1 fêmea, Rio Xingú, 60 km S. Altamira, 52²2’W 339'S, 8-16.X.1986 (P. Spangler \& O. Flint) (USMN); Mato Grosso: 1 fêmea, Utiariti, Rio Papagaio, 1-12.XI.1966 (Lenko \& Pereira) (MZSP); 1 fêmea, Cáceres, 26.I.1985, Malaise (C. Elias) (DZUP); Minas Gerais: 1 fêmea, Belo horizonte, Estação Ecológica UFMG, 04.XII.1996, arm. Malaise (J.C.R.Fontenelle) (UFMG); BOLÍVIA, Santa Cruz: 2 machos, Roboré, X.1959 (SEMC).

\section{Ceyxia atuberculata sp. nov.}

(Figs. 8-9)

Diagnose. Projeção interantenal forma uma carena curta e pilosa; escrobo com carena marginal que se estende por sobre a área parescrobal (Fig. 8); carena frenal suavemente emarginada; pronoto com ruga que delimitam a porção superior do sulco transversal (Fig. 9); metatíbia com espinho apical longo e agudo. 

$\mathrm{mm})$.

Descrição. Fêmea. Comprimento: 5,4-6,2 mm (Holótipo: 6,1

Coloração. Negra, exceto: olho e ocelo castanhos, tégula, $0,75 \mathrm{x}$ basais do escapo; tíbia, metade apical do pró-fêmur e mesofêmur, mancha basal e apical do metafêmur amarelos; asa hialina; pilosidade branca.

Cabeça. Pilosidade cerca de 2x o diâmetro dos umbílicos mais esparsa ao redor do ocelo. Umbílicos da fronte e porção anterior do vértice cerca de $0,25 \mathrm{x}$ o DOA, na porção posterior do vértice umbílicos irregulares; interstício coriáceo. Face inferior com pontuação pilosa, interstício coriáceo. Vértice com perfil arredondado. Face com perfil convexo. Ocelo anterior não toca a margem do escrobo, com carena marginal que se estende por sobre a área parescrobal. Superfície interna lisa. Projeção interantenal forma uma carena curta e pilosa (Fig. 8). Mandíbula bidentada, dente superior vestigial e inferior agudo. Carena pós-orbital encontra a carena genal pouco acima do nível ocular inferior. Carena escrobo-malar irregular e completa. Antena afilada no ápice; escapo não ultrapassa a margem do ocelo anterior. Medidas relativas: cabeça C:A:L 40:50:87; FV 40; LS 25; EPE 5; ETC 10; EM 10; FO 35; DOA 10; APL 6; OOL 5; POL 17; olho A:L:LF 50:35:25; antena: escapo C:L 25:5; pedicelo 4:3; anellus C 2; F1 7:8; F2-F3 6: 11; F4-F6 7: 11; F7 7:10; clava 15:9.

Mesossoma. Dorso convexo, pilosidade cerca de 1,5x o diâmetro dos umbílicos. Umbílicos do pronoto, lobo mediano do mesoscuto e escápula com $0,3 \mathrm{x}$ o DOA; no escutelo atingindo $0,4 \mathrm{x}$ o DOA interstício coriáceo. Carena pronotal ausente na porção mediano-dorsal por 0,5x do FV. Umbílicos da margem posterior do pronoto irregulares, suas margens anteriores formam uma carena evidente. Porção superior da lateral do pronoto coriácea, sulco transversal definido com ruga que delimitam a porção superior (Fig. 9). Escutelo convexo; carena frenal suavemente emarginada. Área frenal lisa, com quatro carenas transversais. Mesepisterno com interstício liso. Carena epicnemial bilobada na porção mediano-ventral. Depressão femoral com algumas carenas transversais curtas e inconspícuas acima da transepimeral. Epímero superior liso. Propódeo areolado com aréola mediana pentagonal. Asa anterior com a dobra basal indicada por duas fileiras de cerdas; dobra cubital com uma fileira de cerdas; célula basal com uma a duas cerdas, linha de cerdas subcubital ausente abaixo da dobra cubital. Metafêmur com dez dentes ventrais. Metatíbia com espinho apical longo e agudo. Medidas relativas: mesossoma C:L 105:80; mesoscuto C 55; escutelo 65:90; asa C:L 185:60; SM 80; M 35; PM 10; ES 5; metacoxa C 45; metafêmur C:L 75:45.

Metassoma. Pecíolo visível dorsalmente; T1 liso com poucas cerdas nas laterais, margem posterior dorsal reta; T2T5 lisos com densa pontuação pilosa e margem posterior ligeiramente côncava. T6-T7 coriáceos com pontuação umbilcada e margem posterior convexa: hipopígio com lobo mediano proeminente. Ápice acuminado. Medidas relativas: gáster C:L 100:55 (+ ovipositor 4); T1 C 59; T7+T8 5:5.

Macho. Semelhante à fêmea exceto por: ápice do gáster truncado truncado; dentes ventrais do metafêmur um pouco maiores que os das fêmeas; espaço entre a margem superior do escrobo; o ocelo anterior menor que nas fêmeas; F1-F3 mais pilosos.

Etimologia. Epíteto específico em referência à ausência do tubérculo na projeção interantenal.

Variações. A carena frenal pode ser suavemente emarginada ou côncava; a coloração do metafêmur pode apresentar uma faixa amarela em toda a extensão da margem externa superior ou apenas uma mancha basal e outra apical; a coloração da face externa da metacoxa pode ser amarela ou preta; a carena marginal do escrobo pode ser inconspícua, assim como as rugas da lateral do pronoto, que delimitam sua margem superior; a carena epicnemial pode ser côncava ou bilobada na porção mediano-ventral.

Distribuição. México, Guatemala, El Salvador, Costa Rica, Panamá, Colômbia Equador, Peru e Brasil (RR, AM, PA, MT, MG).

Hospedeiros. Um exemplar de Trinidad foi criado de ninho de eumenídeo.

Comentários. Ceyxia atuberculata $\mathbf{s p . ~ n o v ~ e ́ ~ s e m e l h a n t e ~ a ̀ ~}$ C. concitator comb. nov. em relação à projeção interantenal e espinho apical da metatíbia, mas pode ser diferenciada desta espécie por apresentar: carena da margem do escrobo que se estende sobre a área parescrobal (Fig. 8); presença de ruga que delimitam a margem superior do sulco transversal do pronoto (Fig. 9) e carena frenal suavemente emarginada na porção mediano-ventral. Esta espécie também é semelhante a C. ventrispinosa e $C$. dentiformis $\mathbf{s p . ~ n o v . , ~ m a s ~ s e ~ d i f e r e n c i a ~}$ por apresentar ocelo anterior distando $0,5 \mathrm{x}$ o DOA da margem do escrobo e a projeção interantenal sem tubérculo.

Material examinado. Holótipo fêmea, com a etiqueta 'Brasil M[inas]G[erais] - Belo Horizonte UFMG, Estação Ecológica 1952'S 4358W 830m 31.V.1996 Malaise E1 J. C. R. Fontenelle, col.' (UFMG). Parátipos. ESTADOS UNIDOS, Florida: Miami, Insp. Station, 23.II.1965 (B.K.Dozier) (USNM). MÉXICO, Veracruz: 1 fêmea, Sontecomapan, U. Mex. Biol. Res. 19.VI.1969, 400 ft (W. R. M. Manson) (CNCI). GUATEMALA, 1 macho, 'on ss', 8.VIII.1934 (J. A. Ramos) (USMN). EL SALVADOR, La Libertad: 1 macho, Quezaltepeque, 18.VI.1963 (D. Q. Cavagnaro \& M. E. Irwin) (CAS); 1 fêmea, ibidem, 22.VI.1963 (UCDC); 1 fêmea, ibidem, 5.VII.1963 (UCDC). COSTA RICA, Puntarenas: 1 fêmea, Osa Peninsula, Corcovado Natl. Park, 27 Km Rincon, 29.II.1984, arm Malaise (S. A. Cameron) (SEMC). PANAMÁ, Zona do Canal: 1 fêmea, Barro Colorado (Phil Rau) (USNM); 1 fêmea, 1 macho, Juan Mina, 25.XI.1918 (H. F. Dietz) (USMN); 1 macho, Juan Mina, citrus plantation, 24.VIII.1918 (H.F.Dietz, J. Zetek) (USMN); Pamaná: 1 fêmea, Chorrera, 30.VIII.1946 (N.L.H.Krauss) (USNM). TRINIDAD: 1 fêmea, Curepe, 20.II.1978, arm. Malaise (Benett) (CNCI); 1 fêmea, Cauca Valley, 11.IX.1937, 'from eumenid nest" (E.Mc Calan) (USNM). COLÔMBIA, Cauca: 1 macho, Cali District, Cauca Valley, 3260 m, 11.II.1935 (Herbert F. Schwarz) (AMNH). VENEZUELA, Zulia: 1 fêmea, Rasario,14.VI.1976 (A.S.Menke, O.Vincent) (USNM); 1 fêmea, 6 km W LA concepcion, 18.VI.1976 (A.S.Menke, O.Vincent) (USNM); Lara: 1 fêmea, $20 \mathrm{~km} \mathrm{E.} \mathrm{Carora,} \mathrm{14.VI.1976} \mathrm{(A.S.Menke,} \mathrm{O.Vincent)}$ (USNM); Aragua: 1 fêmea, Ocumare de La Costa, 21-22.VI.1976 (A.S.Menke, O.Vincent) (USNM). PERU, Huánuco: 2 fêmeas, Monson 
Valley, Tingo Maria, 11.XI.1954 (E.Ischingler e E.S.Ross) (CAS). BRASIL, Roraima: 1 fêmea, Ilha de Maracá, Rio Uraricora, 14.III.1988, arm Malaise (INPA); Amazonas: 1 fêmea, Manaus, Campus UFAM, 30.IX.1978, arm Malaise (J. A. Rafael) (INPA); 1 macho, ibidem, 21.X.1978 (INPA); 1 fêmea, ibidem, 04.XI.1978 (INPA); 2 fêmea, ibidem, 10.II.1979 (INPA); 1 fêmea, ibidem, 15.V.1979 (INPA); 1 macho ibidem, 19.V.1979 (INPA); 2 fêmeas, ibidem, VI.1982 (INPA); 1 fêmea, ibidem, 11.VI.1982 (INPA); 1 fêmea, ibidem, 22-29.VI.1982 (INPA); 1 fêmea, Manaus, Reserva Ducke, 10-17.XI.1988 (Y.Camara, J.E.Bindá) (INPA); 1 fêmea, ibidem, 16.VII.1990, arm Malaise (J. Vidal) (INPA); 1 fêmea, Manaus, Reserva Campina Km 60, Campinarama, 16.IV.1990, arm Malaise (INPA); 1 fêmea, Manaus, ZF3, Km23, Res. 1112, 17.IX.1986, arm. Malaise (Bert. Klein) (INPA); 1 fêmea, Tefé, 10.XII.1919 (H. Parish) (INHS); Pará: 1 fêmea, Caldeirão, R. Itacaiunas, UNICAMP, Ecologia Campo, VII-VII.1985 (Brandão \& Benson) (MZSP), 1 fêmea, São João de Pirabas, Boa Esperança, 18-24.X.1990, arm suspensa (MPEG); 1 fêmea, Serra do Norte, Fofoca, 07-10.X.1985 (MPEG); 1 fêmea Carajás, Serra Norte, Azul, 20-24.VI.1985, arm Malaise (F. F. Ramos) (MPEG); 1 macho, Bragança, Ajuruateua, 23-25.X.1988 (Gorayeb) (MPEG); 1 macho, Vigia, 4.XII.1988, arm. Malaise (I. S. Gorayeb) (MPEG); Mato Grosso: 1 fêmea, Cáceres, 3.XII.1984 (C. Elias) (DZUP); São Paulo: 1 fêmea, Alto da Serra, 06.XI.1906 (H.Luderwaldt) (MZSP).

\section{Ceyxia belfragei (Crawford, 1910) comb. nov., stat. rev.} (Figs. 10-12)

Chalcis belfragei Crawford 1910a: 205 [USA:Texas]. Crawford 1910b: 14.

Brachymeria belfragei: Peck 1951: 586.

Brachymeria (Brachymeria) belfragei: Burks 1960: 237; Burks 1979: 871; De Santis 1979a: 57.

Brachymeria dorsalis: Bouček 1992: 89 (como sinônimo senior de Chalcis belgragei).

Diagnose. Mesoscuto e escutelo castanho-avermelhados; projeção interantenal indicada por uma carena pilosa (Fig. 10); mandíbula bidentada, dente superior afastado do ápice (Fig. 10); ocelo anterior afastado da margem do escrobo por $0,5 \mathrm{x}$ seu diâmetro; carena frenal suavemente emarginada ou côncava (Fig. 11); rugas escrobo-clipeais convergentes delimitando uma área lisa abaixo do escrobo; dentes ventrais do metafêmur aproximadamente do mesmo tamanho (Fig. 12).

Variações. Rugas escrobo-clipeais fracas e incospícuas; partes escurecidas das pernas de negras a marromavermelhadas; face ventral da metacoxa amarela.

Distribuição. Estados Unidos, México, Honduras, Costa Rica*, Panamá e Venezuela*.

\section{Hospedeiros. Desconhecidos.}

Comentários. Burks (1960) apresentou uma redescrição para esta espécie. Bouček (1992) propôs esse nome como sinônimo júnior de Ceyxia dorsalis (Walker) comb. nov., porém, C. belfragei comb. nov. difere dessa por apresentar: mandíbula bidentada (Fig. 10); margem da carena frenal suavemente emarginada ou côncava (Fig. 11); rugas escrobo-clipeais convergentes delimitando uma área lisa abaixo do escrobo; dentes ventrais do metafêmur aproximadamente do mesmo tamanho (Fig. 12). Assim, C. belfragei comb. nov. é aqui revalidado. Os exemplares tratados por Portuondo-F. (2005) como Brachymeria dorsalis (Walker), podem pertencer à $C$. belfragei comb. nov. Na descrição original, Crawford (1910) apresenta as seguintes dados sobre os exemplares tipos: 'Texas, Belfrage collector, 9 specimens. Type - Cat. No. 12780, U.S. National Museum'. Assim, o lectótipo e paralectótipos são designados abaixo. Na coleção do USNM existe uma fêmea etiquetada como type e outros oito exemplares etiquetados como paratype (ver abaixo), todos catalogados sob n ${ }^{\circ} 12780$. Como a primeira está sem a cabeça outra fêmea foi designada como lectótipo.

Material examinado. Lectótipo (aqui designado): 1 fêmea, com as etiquetas 'Texas belfrage' e 'Paratype no. 12780 USNM' (USNM). Paralectótipos (aqui designados): 5 fêmeas, 2 machos, etiquetados 'Texas, Collection, Belfrage' 'Paratype 12.780 USNM'; 1 fêmea (sem cabeça) etiquetada 'Type', 'Chalcis ashmeadii Cwfrd F Type' e 'Chalcis belfragei Crfd, C, Weld' (USNM). Material adicional: ESTADOS UNIDOS, Texas: 4 fêmeas, Uvalde, 24.IX.1931 (R. A. Roberts) (USMN); 1 fêmea, Hidalgo, Bentsen, Rio Grande Valley St[ate] Park, 30.XI2.XII.1978 (E. E. Grissell \& A. S. Menke) (USMN); 1 macho, Browsville, 19.IX.1955, light trap (USMN); 1 fêmea, 'Chalcis belfragei cwfd. det C. Weld'. MÉXICO, Morelos: 1 fêmea, Cuernavaca, XII.1944 (NLH Krauss) (USMN); Yucatan: 2 fêmeas, Chichen Itza, 18.IV.1962 (F. D. Parken, L. A. Stage) (UCDC). HONDURAS: 1 macho, 1 fêmea, 'from banana debris', 'mobile\# 2457', 'Brachymeria belfragei Cwfd. det burks' (USMN). COSTA RICA, Puntarenas: 1 fêmea, $23 \mathrm{Km} \mathrm{NW.} \mathrm{Esparta,}$ 26.VI.1963 (Michener, Wille et al.) (SEMC). PANAMÁ, Zona do Canal: 1 fêmea, Barro Colorado, 16.VII.1923 (R. C. Shannon) (USMN); 1 fêmea, ibidem, 13.VII.1924 (N. Banks) (MCZH). VENEZUELA, Guarico: 1 fêmea, Hato Masaguaral, 44 Km S. Calabozo, 3-10.V.1985 (A. S. Menke \& Carpenter) (USMN); Zulia: 1 fêmea, Carrasquero, 15.VI.1976 (A. S. Menke \& D. Vincent) (USNM); 1 fêmea, Concepción, 16.VI.1976 (A. S. Menke \& D. Vincent) (USNM).

\section{Ceyxia bellissima sp. nov.} (Figs. 46-49)

Diagnose. Projeção interantenal forma uma carena curta e pilosa na porção anterior, escrobo com carena completa (Fig. 47); espaço malar curto; mandíbula com dente inferior robusto e arredondado no ápice; mesossoma e gáster deprimidos dorsalmente; carena epicnemial côncava na porção medianoventral; escutelo com parte central sem umbílicos, intestício liso e brilhante; carena frenal arredondada e com margem refletida para cima (Fig. 48).

Descrição. Fêmea. Comprimento: 7,50-8,3 mm (Holótipo: $8,3 \mathrm{~mm})$.

Coloração. Negra, exceto: olho; ocelo e parte mediana da mandíbula castanhos; escapo, tégula, metade apical do prófêmur e mesofêmur, mancha apical e basal da face externa do metafêmur, tíbia, tarso e coxa amarelos; parte mediana do fêmur e antena marrom; asa hialina; pilosidade dourada.

Cabeça. Pilosidade tão longa quanto 2 x o diâmetro dos umbílicos pouco mais fina e esparsa ao redor dos ocelos. Umbílicos da fronte e porção anterior do vértice com cerca de 0,25x o DOA, na porção posterior do vértice umbílicos irregulares; interstício coriáceo. Face inferior com pontuação irregular, interstício liso. Vértice com perfil arredondado. Face 

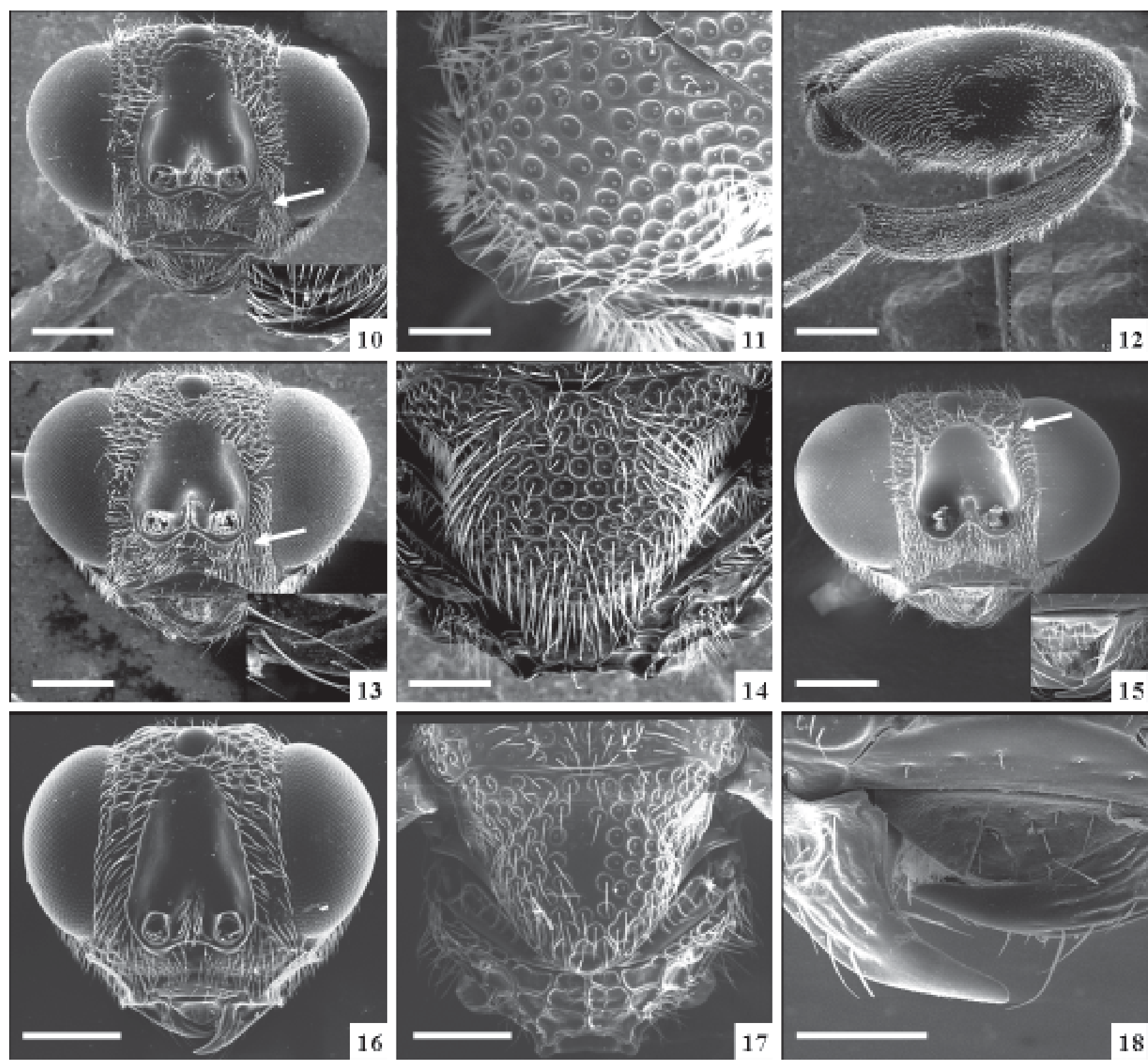

Figs. 10-18. 10-12. Ceyxia belfragei comb. nov., stat. rev., fêmea: 10, cabeça frontal, detalhe da mandíbula e seta indicando carena escrobomalar; 11, escutelo dorsal; 12, metafêmur e metatíbia. 13-14. Ceyxia concitator comb. nov., fêmea: 13, cabeça frontal, detalhe da mandíbula e seta indicando carena escrobo-malar; 14, escutelo dorsal. 15, Ceyxia dentiformis sp. nov., fêmea, cabeça frontal. 16-17. Ceyxia diminuta sp. nov., fêmea: 16, cabeça frontal; 17, escutelo e propódeo dorsal. 18, Ceyxia dorsalis comb. nov., fêmea, mandíbulas. Escala $250 \mu$ m.

com perfil convexo. Ocelo anterior não toca a margem do escrobo; que é completamente carenada (Fig. 47); superfície do escrobo lisa. Projeção interantenal indicada por uma carena curta e pilosa na porção anterior. Mandíbula robusta, bidentada, dente superior vestigial e afastado do ápice (Fig. 46), inferior com ápice arredondado. Carena pós-orbital encontra a carena genal acima do nível ocular inferior. Carena escrobo-malar evidente. Antena estreitada no ápice; escapo não toca a margem do ocelo anterior. Medidas relativas: C:A:L 41:63:105; FV 47; LS 35; EPE 7; ETC 8; EM 10; FO 35; DOA 11; APL 5; OOL 7; POL 14; olho A:L:LF 58:42:38; antena escapo C:L 27:11; pedicelo 6:7; anellus C 3; F1 9:9; F2 10:12; F3-F4 9:13; F5-F6 9:14; F7 8:13; clava 20:12.

Mesossoma. Dorso plano; pilosidade cerca de 2x o diâmetro dos umbílicos, no escutelo $2 \mathrm{x}$ o diâmetro dos umbílicos. Umbílicos do pronoto, margem anterior do lobo mediano do mesoscuto e escápula com $0,25 \mathrm{x}$ o DOA; no restante do lobo mediano e escutelo cerca de $0,5 \mathrm{x}$ o DOA, com parte central sem umbílicos, interstício liso e brilhante. Carena pronotal ausente na porção mediano-dorsal por $0,8 \mathrm{x}$ do FV. Umbílicos da margem posterior do pronoto irregulares, suas margens anteriores formam uma carena anterior evidente. Porção 
superior da lateral do pronoto coriácea, sulco transversal bem definido. Escutelo plano, carena frenal arredondada com margem refletida para cima (Fig. 48). Área frenal lisa sem carenas transversais. Mesepisterno com interstício liso. Carena epicnemial côncava na porção mediano-ventral. Depressão femoral com carenas transversais incompletas acima da transepimeral. Epímero superior liso. Propódeo areoladorugoso, com aréola mediana pentagonal projetada na porção mediana do propódeo. Asa anterior com a dobra basal indicada por duas fileiras de cerdas; dobra cubital com uma fileira de cerdas; célula basal com uma a quatro cerdas; linha de cerdas subcubital presente abaixo da cubital. Metafêmur com nove dentes ventrais, o do meio o maior. Metatíbia com espinho apical curto e rômbico. Medidas relativas: mesossoma C:L 150:95; mesosocuto C 75; escutelo 85:120; asa C:L 235:90; SM 108; M 57; PM 10; ES 5; metacoxa C 60; metafêmur C:L 90:48.

Metassoma. Mesossoma. Deprimido dorsalmente; ápice acuminado; pecíolo visível dorsalmente; $\mathrm{T} 1$ liso com pilosidade látero-dorsal e margem posterior dorsal reta; T3-T5 com densa pilosidade dourada (Fig. 49) e margem posterior ligeiramente côncava; T6-T7 coriáceos com pilosidade látero-dorsal e margem convexa. Medidas relativas: gáster C:L 140:60(+ ovipositor 5); T1 C 80; T7+T8 25:45.

Etimologia. Epíteto específico em referência à beleza de sua coloração e pilosidade.

\section{Distribuição. Costa Rica e Panamá.}

Hospedeiro. Desconhecido.

Comentários. $C$. bellissima sp. nov. se assemelha à $C$. paraensis sp. nov. por apresentar escutelo plano com área central sem pontuações, interstício liso e metassoma deprimido dorsalmente (Fig. 49), mas difere de C. paraensis sp. nov. pela carena frenal arredondada (Fig. 48), porção mediano-ventral da carena epicnemial côncava e pilosidade dourada.

Material examinado. Holótipo fêmea, com a etiqueta 'COSTA RICA, Pta. La Selva, 50 m Seasonal Forest Feb.80 W. Manson' (CNCI). Parátipo. PANAMÁ, Zona do Canal: 1 fêmea, Alhajuelo, IV.1911 (August Busck) (USMN).

\section{Ceyxia concitator (Walker, 1862) comb. nov.} (Figs. 13-14)

Chalcis concitator Walker, 1862: 353 [Brasil: Santarém]. Dalla Torre 1898: 387; Schmiedeknecht 1909: 26.

Chalcis concitata [sic] Kirby 1883: 68.

Brachymeria (Brachymeria) concitator: De Santis 1980: 25-52.

Brachymeria concitator: Bouček 1992: 87, 89-90; Arias \& Delvare 2003: 129 .

Diagnose. Projeção interantenal indicada por uma carena curta e pilosa (Fig. 13); dente superior da mandíbula vestigial e afastado do ápice (Fig. 13); carena frenal bilobada (Fig. 14); espinho apical da metatíbia curto e agudo; carena epicnemial com a porção mediano-ventral bilobada.
Descrição. Fêmea. Comprimento: 4,5-5,8 mm.

Coloração. Negra, exceto: ocelos, olho e ápice da mandíbula castanhos; escapo, tégula, metade apical dos fêmures anterior e médio; manchas basal e apical da face externa do metafêmur, tíbias e tarsos amarelos. Asas hialinas. Pilosidade do tronco branca.

Cabeça. Pilosidade tão longa quanto 2x o diâmetro dos umbílicos, pouco mais esparsa na área ao redor dos ocelos. Umbílicos da fronte e porção anterior do vértice com cerca de $0,25 x$ a 0,3x DOA, na porção posterior do vértice e face inferior umbílicos irregulares; interstício coriáceo, com cerca de $0,5 \mathrm{x}$ o diâmetro dos umbílicos. Vértice com perfil arredondado. Face ligeiramente convexa. Ocelo anterior situado fora do escrobo; este com margem carenada até $0,8 \mathrm{x}$ de sua altura (Fig. 13); superfície interna lisa. Projeção interantenal indicada apenas por uma pequena carena pilosa. Mandíbulas com dente superior vestigial e afastado do ápice, o inferior longo e agudo (Fig. 13). Carena pós-orbital encontra a carena genal pouca acima do nível ocular inferior. Carena occipital conspícua até o forâmen occipital. Antenas subclavadas; escapo não atingindo a margem do ocelo anterior; F1 ligeiramente obcônico. Medidas relativas: cabeça C:A:L 22:30:49; FV 21; LS 15; EPE 5; ETC 6; EM 7; FO 15; DOA 5; APL 4; OOL 3; POL 8; olho A:L:LF 27:20:14; escapo antenal C:L 15:3; pedicelo 3:2; anellus C 1; F1 5:4,5; F2-F5 4:5; F6 5:5; F7 4:5; clava 8:5.

Mesossoma. Dorso convexo; pilosidade cerca de $1,5 \mathrm{x}$ mais longa que o diâmetro dos umbílicos, no escutelo mais que $2 \mathrm{x}$ esse diâmetro. Umbílicos do pronoto, da margem anterior do lobo mediano do mesoscuto e das escápulas 0,4x o DOA; no restante do lobo mediano cerca de $0,5 \mathrm{x}$ o DOA e no escutelo atingindo $0,8 \mathrm{x}$ o DOA; interstício coriáceo, menor que $0,5 \mathrm{x}$ o diâmetro dos umbílicos. Carena pronotal ausente na porção mediano-dorsal por $0,8 \mathrm{x}$ o FV. Umbílicos da margem posterior do pronoto mal definidos formam uma carena conspícua em suas margens anteriores. Porção superior da lateral do pronoto coriácea, sulco transversal normalmente interrompido por uma carena oblíqua. Escutelo convexo; carena frenal muito desenvolvida e emarginada (Fig. 14). Área frenal coriácea e com uma série de carenas transversais inconspícuas. Mesepisterno com interstício liso. Carena epicnemial bilobada na porção mediano-ventral. Depressão femoral com uma série de carenas transversais conspícuas acima da transepimeral. Epímero superior inconspicuamente esculturado. Propódeo com aréola mediana pentagonal como (como na Fig. 23). Asa anterior com a dobra basal indicada por duas fileiras de cerdas; dobra cubital com uma fileira de cerdas; linha de cerdas subcubital presente abaixo da dobra cubital; célula basal normalmente com uma a duas cerdas próximas à dobra basal. Metafêmur com sete a oito dentes na margem inferior, o basal largo e forte, pouco maior que o $3^{\circ}, 4^{\circ}$ ou $5^{\circ}$; pilosidade externa pouco mais longa que $2 \mathrm{x}$ a distância entre os pontos. Espinho apical da metatíbia agudo. Medidas relativas: mesossoma $\mathrm{C}: \mathrm{L}$ 64:43; pronoto C 15; mesoscuto C 25; escutelo C:L 25:25; asa C:L 117:45; SM 51; M 22; PM 8; ES 3; metacoxa C 24; metafêmur C:L 43:23.

Gáster. Pecíolo transverso dorsalmente. T1 0,5x o 
comprimento do gáster; liso e com pontuação pilosa laterodorsal; margem posterior dorsal reta. T2 com margem reta, em T3-5 ligeiramente côncavas. T2-T5 coriáceos, com densa pontuação pilosa nas laterais; no dorso representada por uma fileira de pontos. T6 com densa pontuação umbilicada rasa. Hipopígio com o ápice emarginado medianamente. Ápice acuminado. Medidas relativas: gáster C 62 ( +2 ovipositor); T1 C $34, \mathrm{~T} 7+8$ 10:8.

Macho. Comprimento: 3,6-4,6 mm (Lectótipo: 4,6 mm).

Semelhante à fêmea, exceto por apresentar ápice do gáster não acuminado e pilosidade sensorial mais longa na face ventral dos F2-F7.

Variações. Em alguns exemplares, as porções ventrais do corpo, incluindo as pernas, são marrons. Em outros, as pernas anteriores e médias são amarelas, como ocorre em outras espécies do gênero. A carena frenal pode variar em tamanho e ser mais profundamente emarginada. A carena epicnemial pode ter a porção mediano-ventral bilobada ou quase reta; a margem do ocelo anterior pode não tocar o escrobo; a aréola mediana do propódeo pode ter a porção inferior projetada posteriormente.

Distribuição. México, Belise, Costa Rica, Panamá, Colômbia, Equador, Peru e Brasil (RR*, AM*, PA, RO*, MT*, MS*,).

Hospedeiros. Alguns exemplares examinados foram criados de ninhos de Sphecidae.

Comentários. Esta espécie pode ser reconhecida por apresentar dente superior vestigial afastado do ápice (Fig. 13); projeção interantenal indicada por uma carena curta e pilosa; carena frenal bilobada (Fig. 14); espinho apical da metatíbia curto e agudo; carena epicnemial com a porção mediano-ventral bilobada. Ceyxia concitator comb. nov. é próxima a Ceyxia flaviscapus. Nessa última o dente superior da mandíbula é bem desenvolvido e pouco afastado do ápice, a projeção interantenal forma um tubérculo apical e o ápice da metatíbia não forma espinho apical.

Material examinado. Lectótipo: 1 macho, com as etiquetas 'Braz, Santarem 96 52', 'Santarem', 'Lectotype Bouček 1991', 'concitator', 'Chalcis tipo, Walker stood under this name in old B.M. Coll. C. Waterhouse', 'B.M. Type Hym. 5-455' e 'Brachymeria concitator (W.) Lectotype, Z. Bouček det 1991' (BMNH). Material não-tipo: MEXICO, Oaxaca: 2 fêmeas, Temescal, 15-17.X.1963 (K. H. Janzen) (EMEC). BELIZE, Stann Creek: 1 fêmea, Middlesex, 125M, 20.III.1965 (E. C. Welling) (CNCI). COSTA RICA, Heredia: 2 fêmeas, Est. Biol. La Selva, $10.43^{\circ} \mathrm{N} 84.02^{\circ} \mathrm{W}, 6-11$. VII.1993, arm. Malaise (B. V. Brown \& D. Feener) (LACM). PANAMÁ, Panamá: 1 fêmea, Cabima, V.1911 (August Busck) (USMN); Zona do Canal: 1 fêmea, Ft. Kobbe, II.1953 (F.S. Blanyon) (USMN); Colon: 1 fêmea, Porto Bello, 21.IV.1912 (A. Busck) (USMN). TRINIDAD: 1 fêmea, Lasaivar, Maracás Valley, 5.II.1961 (CNCI); 1 female, sem dados de procedência, polinating Dioscorea trinida (V.C.L.Henry) (USNM); 1 fêmeas, RM Higway, 22.III.1961 (N. Gopaul) (CNCI); 1 fêmea, Arouca, 31.III.1961 (N. Gopaul) (CNCI). COLÔMBIA, Santander: 1 fêmea, Valle de Cachira,
28.VII.1987 (J. Delvare) (INPA). EQUADOR, Pichincha: 1 macho, 16 Km S. E. Santo Domingo, Tinalandia, 680 M, 15-30.VI.1975 (S. \& J. Peck) (CNCI); Napo: 1 fêmea, 1 macho, Coca, IX.86 (G. Onore) (QCAZ); Sucumbios: 1 fêmea, R. Napo, Sacha Lodge, 220M, 22.II4.III.1994 (Peter Hibbs) (QCAZ). PERU, Hиаписо: 1 fêmea, Tingo Maria, Monzon Valley, 10.X.1954 (E. I. Shlinger \& E. S. Ross) (CAS). BRASIL, Roraima: 1 fêmea, Ilha de Maracá, Rio Uraricoera, 0104.III.1988, arm. Shannon (J. A. Rafael) (INPA); 1 macho, ibidem, 213.V.1987, arm. Malaise (J.A.Rafael, J.E.B.Brasil, L.S.Aquino) (INPA). Amazonas: 1 fêmea, Parintins, 10.X.1919 (Parish) (INHS); 1 fêmea, Manaus, ZF3-Km 23 Res. 1301, 12.VI.1985, arm. Malaise (Bert Klain) (INPA); 1 macho, ibidem, Res. 1208, 01.X.1986 (INPA); 1 fêmea, ibidem, Res.1112, 03.XII.1986 (INPA); 1 fêmea, ibidem, Res. 1208 17.XII.1986 (INPA); 1 fêmea, ibidem, Res. 1301, 29.I.1986 (INPA); 1 fêmea, Marãa, R. Japurá, Maguari, 27-31.X.1988, arm Shanon (J. Dias) (MPEG); 1 macho, Reserva Ducke, copa de árvore, 18.I.1982 (J. A. Rafael) (INPA); 1 fêmea, ibidem, 25-29.VII.1992, arm. adesiva 20 m (Vidal \& Vidal) (INPA); 1 macho, Reserva Campina, 08-19.V.1992, arm. adesiva 1 m (J. Vidal \& J. Vidal) (INPA); 1 fêmea, Bejamin Constant, 18-28.IX.1962 (K. Lenko) (MZSP); 3 fêmeas, 1 macho, campus universitário, 22-29.IV.1982 (J.A. Rafael) (INPA); 1 macho, Humaitá, 15-17.IX.1990, arm. suspensa (R. Constantino) (MPEG); Pará: 1 fêmea, Rio Xingú, camp c.a 60 Km S. Altamira, 2-8.X.1986, arm. Malaise (P. Spangler \& O. Flint) (USMN); 2 fêmeas, Conceição do Araguaia, 21-25.V.1983 (J. A. Rafael) (INPA); 1 fêmea, Serra Norte, manganes, 1-3.VII.1985 (M. Zanufo) (MPEG); 1 fêmea, ibidem, Fofoca, 19-23.IX.1985, arm. suspensa 2 m (J. Dias) (MPEG); 1 fêmea, São Felix do Xingu, garimpo da liberdade, 15-19.XI.1991 (B. Mascarenhas) (MPEG); 1 fêmea, Faz. Taperinha, 18-21.IX.1969 (J. M \& B. A. Campbell) (CNCI); 1 fêmea, Benevides, Morelândia, 30.VI02.VII.1988, arm. suspensa 1.6 m (F. F. Ramos) (MPEG); 1 fêmea, Belém, IPEAN, 26.III.1970 (J. M. \& B. A. Campbell) (CNCI); 1 fêmea, ibidem, 2-6.XII.1983, arm. suspensa 1,6 m (I .S. Gorayeb) (MPEG); 1 fêmea, ibidem, florest APEG, 10-14.I.1983; 1 macho, Tucurui, Vila Brava, 15.VII.1980 (Nunes de Melo) (INPA); 1 fêmea, São Joâo de Pirabas, Japerica, 16-18.XII.1992, arm. suspensa (J. Dias) (MPEG); Acre: 1 fêmea, Rio Branco, 25.X-8.XI.1991, mata varzea, arm. suspensa 1,6 m (F. Ramos, A. Henriques, I. Gorayeb, N. Bittencourt) (MPEG); Rondônia: 1 fêmea, Ji-Paraná, 20-23.XI.1984, arm. suspensa 1,6 m (MPEG); 2 fêmeas, Vilhena, Polonoroeste, 29.X e 27.XII.1986 (C. Elias) (DZUP); 1 fêmea, Faz. Rancho Grande, $62 \mathrm{Km} \mathrm{S}$. Ariquemes, 165 m, 12-22.XI.1991 (E.M.Fisher) (UCDC); 1 fêmea, Ouro Preto do Oeste, 13-15.XI.1984, arm. Suspensa 1,6 m (MPEG); Sergipe: 1 fêmea, Santa Luzia do Itanhy, Crasto, 29.VII-01.VIII.2001, arm. Malaise T2 (M. T. Tavares) (MZSP); Bahia: 1 [??], 754, 15/983 (USNM); Mato Grosso: 1 fêmea, Sinop, X.1974 (M. Alvarenga) (CNCI); 1 fêmeas, Rondonópolis, Área Indígena Tadarinama, mata ciliar, 24.X.1991, varredura de vegetação (M. T. Tavares) (UFES); Mato Grosso do Sul: 1 fêmea, Corumbá, março "Lowland" (H. H. Smith) (USNM); Minas Gerais: 1 fêmea, Araporã, Faz. Fac. Agronomia, 19.IX.2002, arm. Malaise (C. H. Marchiori e eq. col) (UFES); Espirito Santo: 1 fêmea, A. Vivacqua, Faz. J. C. Lustosa, 2055'57,6"S 41¹1'22,1'”O, 20 27.II.2003, arm. Malaise B3 (Tavares, Azevedo eq. col) (UFES); 1 fêmea, Pancas, Faz. Juliberto Stur A2, 19²12'54"S 4047'52"O, 24 31.I.2003, arm. Malaise B6 (M. T. Tavares eq. col) (UFES); 1 fêmea, Santa Tereza, Estação Biol. de Santa Lúcia, [ex. ninho de barro de vespa], 31.VII.04 (T. Andrade) (UFES); 1 fêmea, Cariacica, Res. Biol. Duas Bocas, 24.IX.1996, varredura de vegetação (Azevedo e Santos) (UFES); Rio de Janeiro: 3 fêmeas, Itatiaia, 6.I.1944, XI.1947 e 12.X.1948 (J.F.Zikan) (FIOC); 1 macho, Silva Jardim, VIII.1974 (F. M. Oliveira) (CNCI); Paraná: 1 fêmea, Piraquara, 13.I.1968 (MoureLaroca) (DZUP); Santa Catarina: 1 macho, Nova Teotonia, 27 $11^{\prime}$ 'S52 $23^{\circ} \mathrm{W}, 300-500 \mathrm{~m}, \mathrm{VII} .1970$ (Fritz Plaumann) (CNCI). BOLIVIA, el Beni: Rio Mamora, 10Km E. San Antonio, 11.VII.1965 (J.E.Bouseman) (AMNH); Santa Cruz: 1 fêmea, Roboré, X.1959 (SEMC). Localidades desconhecidas: 2 fêmeas, 7.IX.1954 e 31.I.1932 (FIOC); 1 fêmea, Brazil, Beira de Igarapé (MPEG). 


\section{Ceyxia decreta (Walker, 1862) comb. nov.}

Chalcis decreta Walker 1862: 352-353 [Brasil: Santarém]. Dalla Torre 1898: 387; Ashmead 1904: 409; Schmiedeknecht 1909: 26.

Chalcis eurytomoides Walker 1864: 207 [Brasil]. Dalla Torre 1898: 387; Ashmead 1904: 409; Schmiedeknecht 1909: 26; Bouček 1992: 89 (designação de sinonímia).

Chalcis vicaria Walker 1861: Kirby 1883: 68 (como sinônimo sênior de $C$. decreta)

Brachymeria (Brachymeria) decreta (Walker): De Santis 1980: 252.

Brachymeria (Brachymeria) vicaria (Walker): De Santis 1980: 253 (como sinônimo sênior de $C$. erytomoides)

Brachymeria decreta (Walker): Bouček 1992: 89; Arias \& Delvare 2003: 129 .

Diagnose. Projeção interantenal indicada por uma carena curta e pilosa; OOL maior ou igual ao DOA; mandíbulas com dente superior bem desenvolvido e apical; carena frenal trapezoidal com margem posterior reta ou ligeiramente ondulada; espinho apical da metatíbia distinto, ápice agudo; gáster no mínimo 1,5x mais longo que o mesossoma. $\mathrm{mm})$.

Descrição. Fêmea. Comprimento: 5,7-8,0 mm (Lectótipo 6,4

Coloração. Negra, exceto: olho e ocelos castanhos; escapo, tégula, metade apical do fêmur anterior, 1/4 apical do fêmur médio, face ventral da metacoxa, manchas basal e apical da face externa do metafêmur, tíbias e tarsos amarelos. Asas ligeiramente enegrecidas. Pilosidade da cabeça branca, do dorso do mesossoma e metassoma amarelada.

Cabeça. Pilosidade pouco mais longa que 2x o diâmetro dos umbílicos, mais esparsa na área ao redor dos ocelos. Umbílicos da fronte e porção anterior do vértice com cerca de 0,4x o DOA, na porção posterior do vértice irregulares; interstício coriáceo, cerca de $0,5 x$ o diâmetro dos umbílicos. Face inferior com pontos pilosos diminutos, quase lisa. Vértice com perfil arredondado. Face convexa. Ocelo anterior dista ao menos seu próprio diâmetro do topo do escrobo. OOL maior ou igual ao DOA. Escrobo com margem carenada até muito próximo do topo; superfície interna inconspicuamente esculturada próximo às margens, lisa no centro. Projeção interantenal indicada por uma curta carena pilosa. Mandíbulas bidentadas; dente superior apical e menor que o inferior. Carena pós-orbital encontra a carena genal no nível inferior dos olhos. Carena occipital conspícua até o forâmen occipital. Antenas robustas, estreitadas no ápice; escapo não atingindo a margem do ocelo anterior; F1 obcônico. Medidas relativas: C:A:L 22:33:55; FV 25; LS 19; EPE 6; ETC 7; EM 7; FO 20; DOA 5 APL 4;; OOL 5; POL 9; olho A:L:LF 30:21:14; escapo antenal C:L 15:3; pedicelo 3:3; anellus C 1; F1 6:6; F2-F4 5:7; F5-F6 4,5:7; F7 4:6; clava 10:6.

Mesossoma. Dorso convexo, pilosidade pouco mais curta que diâmetro dos umbílicos, no escutelo 2x esse diâmetro. Umbílicos do pronoto $0,5 \mathrm{x}$ o DOA; na margem anterior do lobo mediano do mesoscuto e escápulas $0,3 \mathrm{x}$ o DOA; no centro do lobo mediano e no escutelo atingindo 0,6x o DOA; interstício coriáceo, menor que $0,5 \mathrm{x}$ diâmetro dos umbílicos. Carena pronotal ausente na porção mediano-dorsal por $0,7 x$ o FV. Umbílicos da margem posterior do pronoto conspícuos formando uma carena em suas margens anteriores. Porção superior da lateral do pronoto coriácea, sulco transversal conspícuo. Escutelo convexo; carena frenal desenvolvida, trapezoidal, com margem reta. Área frenal com três a quatro carenas transversais inconspícuas, interstício liso. Mesepisterno com interstício liso. Carena epicnemial emarginada na porção mediano-ventral. Área subalar inconspicuamente esculturada. Depressão femoral lisa, exceto por algumas carenas transversais curtas e inconspícuas acima da transepimeral. Epímero superior liso, inconspicuamente esculturado acima. Aréola pentagonal do propódeo conspícua, alongada. Asa anterior com a dobra basal com uma a três fileiras de cerdas; a cubital com uma fileira de cerdas; linha de cerdas subcubital presente abaixo da dobra cubital; célula basal normalmente com algumas cerdas próximo à dobra basal. Metafêmur com seis a oito dentes na margem inferior, o basal largo e forte, o $5^{\circ}$ e o $6^{\circ}$ os maiores; pilosidade externa pouco mais longa que $2 \mathrm{x}$ a distância entre os pontos. Espinho apical da metatíbia agudo e ligeiramente curvo. Medidas relativas: mesossoma C:L 67:47; pronoto C 15; mesoscuto C 28; escutelo C:L 26:26; asa C:L 127:50, SM 55, M 24, PM 9, ES 3; metacoxa C 30; metafêmur C:L 48:26.

Metassoma. Distintamente alongado, mais que 1,7x o comprimento do mesossoma. Pecíolo dorsalmente transverso. T1 ligeiramente menor que $0,5 \mathrm{x}$ o comprimeto do gáster; liso e com pontuação pilosa latero-dorsal; margem posterior dorsal reta. T2-T5 com margem dorsal ligeiramente côncava; coriáceos, com pontuação pilosa nas laterais; no dorso representada por uma fileira de pontos. T6 com umbílicos rasos e mal definidos, intestício inconspicuamente esculturado. Hipopígio com o ápice emarginado medianamente. Ápice acuminado. Medidas relativas: gáster C 84 (+ 5 ovipositor); T1 C 40, T7+8 C:L 10:13.

Macho. Comprimento 4,5 mm.

Semelhante à fêmea, exceto por apresentar o ápice do gáster não acuminado e pilosidade sensorial na face ventral de F1-F4 mais longa.

Variações. As tíbias podem ter uma faixa anelar mediana enegrecida. A face ventral da metacoxa pode ser marrom ou negra. OOL varia um pouco, mas é no mínimo o DOA. A carena frenal pode ter a margem ligeiramente ondulada.

Distribuição. Equador*, Peru* e Brasil (AM*, PA e MT).

Hospedeiro. Desconhecido.

Comentários. Kirby (1883) designou erroneamente este nome como sinônimo júnior de Chalcis vicaria Walker [atualmente sinonimo júnior de B. mnestor (Walker)], proposta seguida por De Santis (1980). Esta espécie se diferencia das demais por apresentar projeção interantenal indicada por uma carena baixa, mandíbula com dente superior bem desenvolvido, carena frenal trapezoidal e gáster com cerca de $1,7 \mathrm{x}$ mais longo que o mesossoma. 

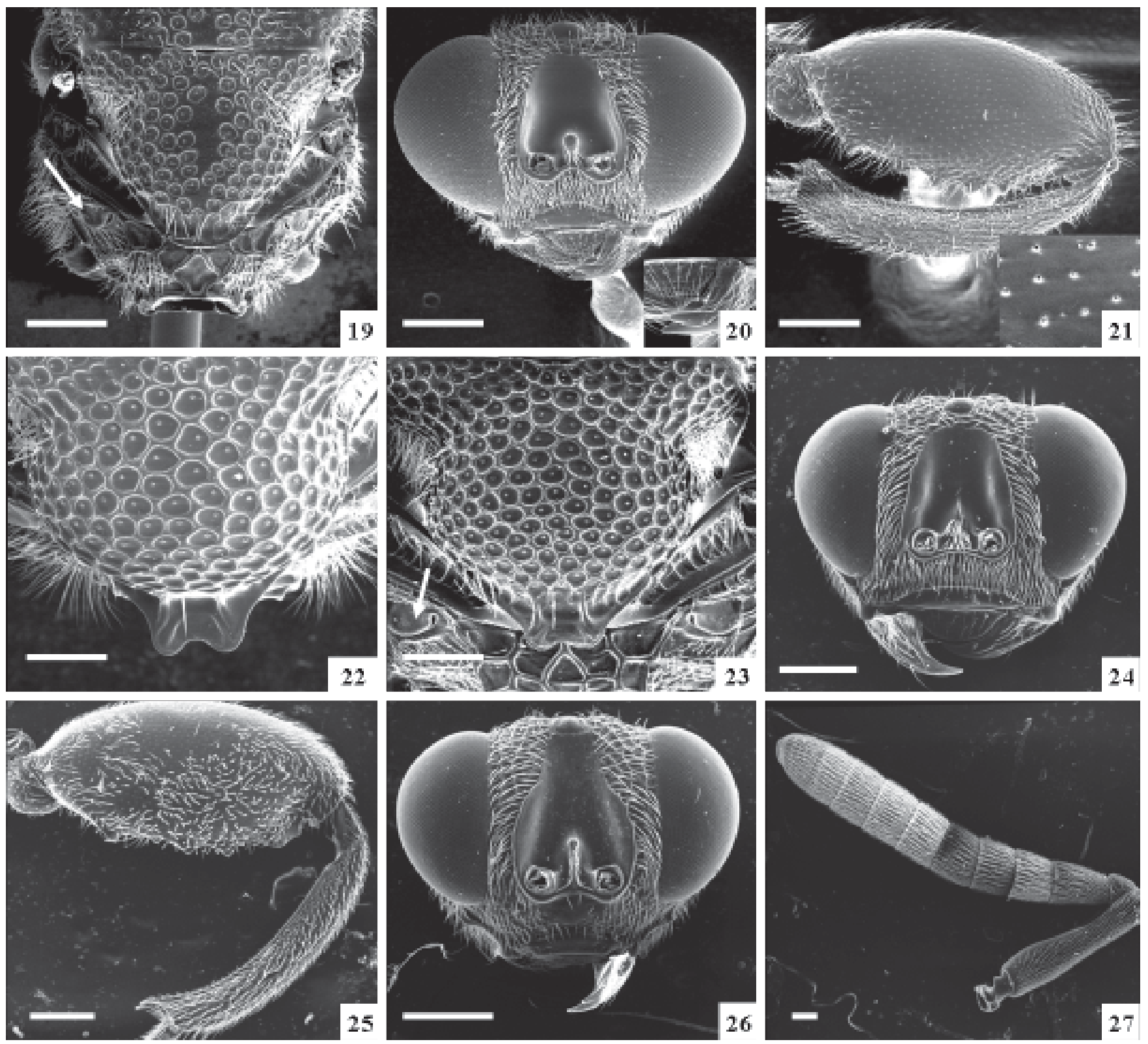

Figs. 19-27. 19, Ceyxia dorsalis comb. nov., fêmea, escutelo e propódeo dorsal, indicando a projeção posterior da margem do espiráculo. 20-23. Ceyxia flaviscapus, fêmea: 20, cabeça frontal e detalhe da mandíbula; 21, metafêmur e metatíbia, detalhe da superfície do metafêmur; 22, escutelo dorsal; 23, escutelo dorsal, indicando a projeção posterior da margem do espiráculo. 24-25. Ceyxia laticlipeata sp. nov., fêmea: 24, cabeça frontal; 25, metafêmur e metatíbia. 26-27. Ceyxia longispina sp. nov., fêmea: 26, cabeça frontal; 27, antena. Escala $250 \mu \mathrm{m}$.

Material examinado. Material tipo. Chalcis decreta: 1 fêmea (Lectótipo), com as etiquetas 'Braz, Santarém 52 96', 'Brachymeria decreta (Walker, 1962)', 'BM Type Hym. 5456' e 'Brachymeria decreta (Walker,1862), Lectotype, fêmea, Z. Bouček det 1991' (BMNH). Chalcis. eurytomoides: 1 fêmea (Lectótipo); 'Braz 62 5b', 'Brazil', 'Lectotype Bouček 1991', 'eurytomoides (type)', 'Chalcis eurytomoides Walker stood under...', 'B. M. Type Hym 5.458', 'Lectotype, Chalcis eurytomoides W. 64, Z. Bouček det 1991' e 'Brachymeria decreta fêmea Bouček det 1991' (BMNH). Material não-tipo: EQUADOR, Napo: 1 fêmea, Coca, II.1986 (G. Onore) (QCAZ). PERU, Hиаписо: 1 fêmea, Tingo Maria, X.1947, $670 \mathrm{~m}$ (W Weyrauch) (USMN). BRASIL, Amazonas: 1 macho, Manaus, Campus Universitário, 11.VI.1981, arm Malaise (J. A. Rafael) (INPA); 1 fêmea, Tefé, 10.XII.1919 (H. Parish) (INHS).

\section{Ceyxia dentiformis sp. nov.}

(Fig. 15)

Diagnose. Carena marginal do escrobo deriva por sobre a área parescrobal (Fig. 15); projeção interantenal dentiforme; ocelo anterior distante do topo do escrobo por ao menos o diâmetro do DOA.

Descrição. Fêmea. Comprimento: 5,7-6,5 mm (Holótipo: 5,8 $\mathrm{mm})$.

Coloração. Negra, exceto: olho e ocelo castanhos; tégula; 
escapo; tíbia, metade apical do pró-fêmur, mancha apical e basal do metafêmur amarelos; asa esfumaçada; pilosidade branca.

Cabeça. Pilosidade 2x o diâmetro dos umbílicos, mais esparsa ao redor dos ocelos. Umbílicos da fronte e porção anterior do vértice com cerca de $0,25 x$ o DOA, na porção posterior do vértice pontuação umbilicada rasa e irregular; interstício coriáceo. Face inferior com pontuação pilosa, interstício coriáceo. Vértice com perfil arredondado. Face com perfil convexo. Ocelo anterior não toca a margem do escrobo; este com carena marginal que se estende por sobre a área parescrobal, superfície interna lisa. Projeção interantenal dentiforme (Fig. 15). Mandíbula bidentada, dente superior vestigial afastado do ápice, o inferior longo e agudo (Fig. 15). Carena pós-orbital encontra a carena genal pouco acima do nível ocular inferior. Carena escrobo-malar completa. Antena afilada no ápice; escapo não toca a margem do ocelo anterior. Medidas relativas: cabeça C:A:L 30:50:85; FV 35; LS: 25; EPE 8; ETC 10; EM 10; FO 30; DOA 10; APL 6; OOL 5; POL 15; olho A:L:LF 55:40:30 antena; anellus $C$ 3; escapo C:L 30:8; pedicelo 5:5; F110:9; F2 7:10; F3 8:10; F4-F7 7:10; clava 15:8.

Mesossoma. Dorso convexo, pilosidade cerca de 1,5x o diâmetro dos umbílicos. Umbílicos do pronoto, margem anterior do lobo mediano do mesoscuto e escápula com $0,2 \mathrm{x}$ o DOA; no restante do lobo mediano cerca de $0,3 \mathrm{x}$ o DOA e no escutelo atingindo $0,4 \mathrm{x}$ o DOA interstício coriáceo. Carena pronotal ausente na porção mediano-dorsal por $0,8 \mathrm{x}$ do $\mathrm{FV}$. Umbílicos da margem posterior do pronoto irregulares, suas margens anteriores formam uma carena anterior evidente. Porção superior da lateral do pronoto coriácea, sulco transversal definido com rugas que delimitam a porção superior. Escutelo convexo; carena frenal côncava. Área frenal rugosa com três carenas transversais. Mesepisterno com interstício liso. Carena epicnemial côncava na porção mediano-ventral. Depressão femoral com algumas carenas inconspícuas acima da transepimeral. Epímero superior liso. Propódeo areolado com aréola mediana pentagonal. Asa anterior com a dobra basal indicada por duas fileiras de cerdas; dobra cubital com duas fileiras de cerdas; célula basal glabra, linha de cerdas subcubital presente abaixo da dobra cubital. Metafêmur com onze dentes ventrais. Metatíbia com espinho apical longo e agudo. Medidas relativas: mesossoma C:L 105:80; mesoscuto C 70; escutelo 90:100; asa C:L 165:60; SM 65; M 35; PM 10; ES 5; metacoxa C 45; metafêmur C:L 75:40.

Metassoma. Pecíolo visível dorsalmente; T1 liso com poucas cerdas e com pontuações na margem posterior reta; T2-T5 lisos com densa pontuação diminuta e margem posterior ligeiramente côncava; T6-T7 coriáceos com pontuação umbilicada e margem posterior convexa; hipopígio com lobo mediano proeminente. Ápice acuminado. Medidas relativas: gáster C:L 95:53 (+ ovipositor 5); T1 C 55; T7+T8: 5:5.

Macho. Semelhante à fêmea exceto por apresentar o último segmento do gáster truncado.

Etimologia. Epíteto específico em referência à projeção interantenal dentiforme.
Variações. Nesta espécie o número de dentes ventrais do metafêmur pode variar de onze a doze, a projeção interantenal pode ser mais desenvolvida e a coloração da face ventral da metacoxa pode ser completamente negra ou apresentar manchas amarelas.

\section{Distribuição. Brasil (DF, MG, RJ, SP).}

Hospedeiro. Desconhecido.

Comentários. Esta espécie, C. ventrispinosa, C. amazonica sp. nov. e $C$. atuberculata sp. nov. apresentam a carena marginal do escrobo se estendendo por sobre a área parescrobal (Fig. 15), mas $C$. dentiformis sp. nov. se diferencia dessas e das outras espécies do grupo por apresentar a projeção interantenal dentiforme.

Material examinado. Holótipo fêmea. 'BRASIL - M[inas]G[erais] - Belo Horizonte UFMG, Estação Ecológica 1952'S, 4358'W, 830m 27.XI.1996, Malaise E1 J. C. R. Fontenelle, col.' (UFMG). Parátipos. BRASIL, Distrito Federal: 1 fêmea, Reserva Ecológica IBGE Km 0 BR 251, 11-25.IX.1981 (IBGE); 1 fêmea, ibidem, 18-25.XI.1982 (IBGE); Minas Gerais: 11 fêmeas, mesmos dados que holótipo (UFMG); 1 fêmea, ibidem, 07.VI.1996 (UFMG); 2 fêmeas, ibidem, 24.XI.1996 (UFMG); 2 fêmeas, ibidem, 25.XI.1996 (UFMG); 1 fêmea, ibidem, 26.XI.1996 (UFMG); 1 fêmea, ibidem, 02.XII.1996 (UFMG); 3 fêmeas, ibidem, 04.XII.1996 (UFMG); 1 fêmea, Serra do Caraça, 27.XI-5.XII.1972 (MZSP); Rio de Janeiro: 1 macho, Itatiaia, $700 \mathrm{~m}$, Camboatá, 10.VI.1929 (J. F. Zikan) (FIOC); São Paulo: 1 fêmea, São Carlos, Faz Canchim, Cerrado, 27.XII.1989, arm suspensa (N.W. Perioto) (DCBU); 1 fêmea, Ilha dos Búzios, 16.X-4.XI.1963 (MZSP). BOLÍVIA, Santa Cruz: 2 fêmea, Bororé, X.1959 (SEMC).

\section{Ceyxia diminuta sp. nov.}

(Figs. 16-17)

Diagnose. Cabeça globosa; projeção interantenal indicada por uma carena curta e pilosa na porção anterior; carena escrobo-malar inconspícua e incompleta; segmentos funiculares mais largos que longos; escutelo deprimido dorsalmente, com região central sem umbílicos (Fig. 17), interstício coriáceo; asa com célula basal glabra; metassoma com T1 muito longo em relação ao seu comprimento; margem do hipopígio convexa.

Descrição. Fêmea. Comprimento: 4,3-4,8 mm (Holótipo: 4,4 $\mathrm{mm})$.

Coloração. Negra, exceto: olho e ocelo castanhos; tégula, metade apical do pró-fêmur e mesofêmur, pró-tíbia e mesotíbia,, quarto basal e apical da metatíbia, mancha apical e basal da face externa do metafêmur e metacoxa amarelos; asa hialina; pilosidade branca.

Cabeça. Pilosidade tão longa quanto $2 \mathrm{x}$ o tamanho dos umbílicos, mais esparsa e fina ao redor dos ocelos. Umbílicos da fronte e porção anterior do vértice com cerca de $0,25 \mathrm{x}$ do DOA, na porção posterior do vértice umbílicos irregulares; interstício coriáceo. Face inferior com pontuação irregular, interstício coriáceo. Vértice com perfil arredondado. Face com perfil convexo. Ocelo anterior não toca a margem do escrobo 
(Fig. 16); este com margem carenada até $0,75 x$ de sua altura; superfície interna lisa. Projeção interantenal indicada por uma carena curta e pilosa na porção anterior. Mandíbula bidentada, dente superior vestigial e afastado do ápice, o inferior longo e agudo. Carena pós-orbital encontra a carena genal no nível da margem inferior dos olhos. Carena escrobo-malar inconspícua e incompleta. Antena alargada no ápice; escapo não ultrapassa a margem inferior do ocelo anterior. Medidas relativas: cabeça C:A:L 30:42:68; FV 30; LS 20; EPE 5; ETC 5; EM 5; FO 20; DOA 7; APL 7; OOL 3; POL 13; olho A:L:LF 37:25:20; antena: escapo C:L 24:7; pedicelo 5:5, anellus C 2; F1-F2 5:6, F3 5:7; F4-F5 5:8; F6 4:9; F7 5:9; clava 12:9.

Mesossoma. Dorso plano; pilosidade cerca de $2 \mathrm{x}$ o diâmetro dos umbílicos, no escutelo mais que $2 \mathrm{x}$ esta medida. Umbílicos do pronoto, lobo mediano do mesoscuto e escápula com $0,3 \mathrm{x}$ o DOA; no escutelo atingindo 0,4x o DOA, com área central sem umbílicos; interstício coriáceo. Carena pronotal ausente na porção mediano-dorsal por 0,6x do FV. Umbílicos da margem posterior do pronoto irregulares, suas margens anteriores formam uma carena anterior evidente. Porção superior da lateral do pronoto coriácea; sulco transversal interrompido por carena mediana oblíqua. Escutelo plano; carena frenal arredondada (Fig. 17). Área frenal coriácea com três carenas transversais inconspícuas. Mesepisterno com interstício liso. Carena epicnemial côncava na porção mediano-ventral. Depressão femoral com algumas carenas interrompidas acima da transepimeral. Epímero superior coriáceo. Propódeo areoladorugoso com carena mediana completa, sem formar aréola pentagonal (Fig. 17). Asa anterior com a dobra basal indicada por duas fileiras de cerdas; dobra cubital indicada por uma fileira de cerdas; célula basal glabra linha de cerdas subcubital presente abaixo da dobra cubital. Metafêmur com parte basal mais larga que longa, com oito a onze dentes ventrais. Ápice da metatíbia curto, curvo e rômbico. Medidas relativas: mesossoma C:L 74:60; mesoscuto C 40; escutelo 42:50; asa C:L 125:52; SM 55; M 22; PM 5; ES 4; metacoxa C 30; metafêmur C:L 55:27.

Metassoma. Pecíolo visível dorsalmente; T1 liso, com pouca pilosidade látero-dorsal e margem posterior reta; T2-T5 coriáceos, com pilosidade látero-dorsal e margem ligeiramente côncava; T6-T7 coriáceos com pilosidade látero-dorsal e margem convexa; margem do hipopígio convexa. Ápice acuminado. Medidas relativas: gáster C:L 70:50 (+ ovipositor 3) T1 C 40; T7+T8 5:5.

Macho. Semelhante à fêmea exceto por apresentar o ápice do gáster truncado.

Etimologia. Epíteto específico em referência ao tamanho reduzido do corpo.

Variações. Sulco transversal do pronoto interrompido ou não por uma carena mediana; metacoxa negra ou com manchas amarelas na face ventral; metafêmur negro ou com manchas amarelas basais e apicais; metafêmur com de oito a onze dentes na margem inferior; mesopleura com carenas transversais interrompidas ou não; carena mediana do propódeo com ou sem aréola pentagonal.
Distribuição. El Salvador, Trinidad, Brasil (AM, PA, MT, MS, GO, MG, ES, SP, RJ, PR).

Hospedeiros. Desconhecidos.

Comentários. Esta espécie é semelhante a C. tibiodilatata sp. nov. por apresentar a carena mediana do propódeo completa, mas pode ser diferenciada através do espinho da metatíbia curto, curvo e rômbico, pelo T2-T5 coriáceos e metafêmur com parte basal mais larga que longa.

Material examinado. Holótipo fêmea com as etiquetas 'BRASIL: ES, Vitória área urbana 29.XII-22.I.2004 R. Kawada, col.' (UFES). Parátipos. EL SALVADOR, La Liberta: 1 fêmea, Santa Tecla, VIII.1975 (N.L.H. Krauss) (USMN). TRINIDAD, "cocoon in cotton", 3.II.1949 (P. C. Attick) (USMN). BRASIL, Amazonas: 1 fêmea, Manaus, Reserva Campina, 8-19.VI.1992, interceptação de vôo (J. Vidal \& J. Vidal) (INPA); 1 macho, Manaus, Reserva Ducke, 8-15.VI.1992, arm. adesiva (INPA); 1 fêmea, Manaus, Reserva Ducke, 8-10.VIII.1981, "Flight trap" (INPA); Pará: 1 fêmea, Carajás, S. Norte-Azul, 20-24.V.1995, Malaise (F. F. Ramos) (MPEG); Goiás: 1 exemplar (sem gaster), Itumbiara, Faz. Fac. Agronomia, 25.VII.2002, arm. Malaise (C.H.Marchiori) (UFES); Mato Grosso: 1 fêmea, Cáceres, XI.1984 (C. Elias) (DZUP); Mato Grosso do Sul: 1 fêmea, Corumbá, Passo da Lontra, 8-12.XI.1993, armadilha suspensa (L. Joaquim) (DCBU); Rio de Janeiro: 1 fêmea, Rio de Janeiro, I.1938 (Dario Mendes) (MNRJ); 1 fêmea, Itatiaia, 6.II.47 (J. F. Zikan) (FIOC); 1 macho, Rio de Janeiro, Grajahu, 4.I.1941 (Lopes) (FIOC); São Paulo, 1 fêmea, São Carlos, 12.VI.1990, arm. Moericke (R. K. Takata) (DCBU); 1 fêmea, Ubatuba, Base. Inst. Ocean, 26.I-9.II.1971, luz (P. Montouchet) (MZSP); Minas Gerais: 1 fêmea, Belo Horizonte, 1952'S, 435' 'W, 28.XI.1996, Malaise (J. C. R. Fontenelle) (UFMG); 1 macho, ibidem, 24.XI.1996 (UFMG); Espírito Santo: 4 fêmeas, Vitória, área urbana, 3-5.XII.2004 (R. Kawada) (UFES); 2 fêmeas, ibidem, 29.XII-22.I.2004 (UFES); 1 fêmea, ibidem, 5.V.2004 (UFES); 3 fêmeas, ibidem, 10-11.XII.2004 (UFES); 1 fêmea, ibidem, 11.IV.2004 (UFES); 1 fêmea, ibidem, 27.XI.2004 (UFES); Santa Catarina: 2 fêmeas, Nova Teutonia, $27^{\circ} 11^{\prime} \mathrm{S}$ 52 ${ }^{\circ} 23^{\prime}$ W, 1.IV.1965 (Fritz. Plaumann) (LACM); 1 fêmea, ibidem, 26.II.1964 (MCZH). Outros exemplares estudados: BRASIL, Espírito Santo: 1 fêmea, Vitória, área urbana, 4.XI.2004 (R.Kawada) (utilizado em microscopia eletrônica de varredura) (UFES).

\section{Ceyxia dorsalis (Walker, 1861) comb. nov.} (Figs. 18-19)

Haltichella dorsalis Walker, 1861: 185 [Brasil: Santarém]. Dalla Torre 1898: 397; Ashmead 1904: 457; Schmiedeknecht 1909: 57; De Santis 1980: 247.

Brachymeria dorsalis: Bouček 1992: 89; Arias \& Delvare 2003: 129; Portuondo-F. 2005: 238.

Diagnose. Projeção interantenal indicada por uma suave elevação da superfície do escrobo; mandíbula alongada e unidentada (Fig. 18). Mesoscuto e escutelo marromavermelhados; escutelo plano, com interstício da área central maior que o diâmetro dos umbílicos (Fig. 19); carena frenal arredondada (Fig. 19), carena epicnemial reta na porção mediano-ventral; metafêmur com o $1^{\circ}$ e o $4^{\circ}$ dentes da margem inferior maiores que os demais.

Descrição. Fêmea. Comprimento: 3,4-5,0 mm.

Coloração. Negra, exceto: dorso do mesossoma e face ventral da metacoxa marrom-avermelhados; olho e ocelos 
castanhos; 2/3 basal do escapo, tégula, metade apical dos fêmures anterior e médio, tíbia anterior e média, face ventral da coxa posterior, $1 / 5$ basal e mancha apical na face externa do metafêmur, 2/5 apical da metatíbia, e tarsos amarelos. Asas ligeiramente enegrecidas. Pilosidade branca.

Cabeça. Pilosidade pouco mais esparsa na área ao redor dos ocelos. Umbílicos da fronte e porção anterior do vértice com 0,16x o DOA, na porção posterior do vértice irregulares; interstício coriáceo, cerca de $0,5 \mathrm{x}$ diâmetro dos umbílicos; face inferior com umbílicos rasos e pouco definidos. Vértice com perfil arredondado. Ocelo anterior situado fora do escrobo. Face com perfil ligeiramente convexo. Escrobo com margem carenada até $0,75 \mathrm{x}$ de sua altura; superfície interna inconspicuamente esculturada nas margens laterais, no restante lisa. Projeção interantenal indicada apenas por uma suave elevação da superfície do escrobo, densamente pilosa. Mandíbulas unidentadas e alongadas (Fig. 18). Carena pósorbital encontra a carena genal pouca acima do nível ocular inferior. Carena occipital conspícua em toda a sua extensão. Antenas subclavadas; escapo não atingindo o ocelo anterior; F1 obcônico. Medidas relativas: C:A:L 23:31: 50; FV 22; LS 17; EPE 6; ETC 7; EM 6; FO 21; DOA 5.5; APL 3; OOL 2.5; POL 8; olho A:L:LF 27:22:14; escapo antenal C:L 17:5; pedicelo 5:3; anellus $\mathrm{C}$ 2; F1 6:5; F2-F5 4,5:6; F6-F7 5:6; clava 9:6.

Mesossoma. Dorso convexo, pilosidade 1,5x mais longa que diâmetro dos umbílicos, no escutelo atingindo $3 \mathrm{x}$ esse diâmetro. Umbilicos do pronoto, margem anterior do lobo mediano do mesoscuto $0,25 \mathrm{x}$ o DOA; no restante do lobo mediano e no escutelo atingindo $0,3 \mathrm{x}$ o DOA, nas escápulas pouco menores que os do pronoto; interstício coriáceo, no pronoto menor que $0,5 \mathrm{x}$ o diâmetro dos umbílicos, no mesoscuto pouco maiores que $0,5 x$ esse diâmetro, no escutelo cerca de $0,5 \mathrm{x}$ o diâmetro dos umbílicos, exceto na área central onde o interstíco é tão amplo quanto esse diâmetro e forma área ou faixa mediana sem umbílicos (Fig. 19), que pode se prolongar através do lobo mediano do mesoscuto; nas escápulas interstício maior que o diâmetro dos umbílicos. Carena pronotal ausente na porção mediano-dorsal 1,0x o FV. Umbílicos da margem posterior do pronoto mal definidos formamando uma carena conspícua em suas margens anteriores. Porção superior da lateral do pronoto coriácea, sulco transversal conspícuo. Escutelo ligeiramente convexo, quase plano; carena frenal com margem arredondada (Fig. 19), voltada para cima. Área frenal com algumas carenas transversais delicadase e interstício inconspicuamente esculturado. Mesepisterno com interstício liso. Carena epicnemial conspícua, ligeiramente concava na porção mediano-ventral. Área subalar lisa. Depressão femoral com algumas carenas transversais irregulares e incompletas acima da transepimeral mais visíveis ao longo da margem anterior. Epímero superior liso, irregularmente estriado na porção superior. Propódeo com aréola mediana (Fig. 19). Asa anterior com a dobra basal indicada por duas a três fileiras de cerdas; dobra cubital com uma fileira de cerdas; linha de cerdas subcubital presente abaixo da dobra cubital; célula basal com uma a três cerdas próximo à dobra basal. Metafêmur com oito a nove dentes na margem inferior, o basal largo e forte, $\mathrm{o} 4^{\circ} \mathrm{o}$ maior; pilosidade e pontuação como em C. belfragei comb. nov. (Fig. 12). Espinho apical da metatíbia curto e agudo, com margem interna reta. Medidas relativas: mesossoma C:L 70:49; pronoto C 11; mesoscuto C 28; escutelo C:L 21:21; asa C:L 125:47, SM 51, M 29, PM 6, ES 2; metacoxa C 27; metafêmur C:L 49:24.

Metassoma. Pecíolo dorsalmente transverso. T1 com cerca de $0,5 \mathrm{x}$ o comprimento do gáster; liso e com pontos pilosos latero-dorsais; margem posterior dorsal reta. T2-T4 com margem ligeiramente côncava. T2-T5 coriáceos, com densa pontuação pilosa nas laterais; no dorso representada por uma fileira de pontos. T6 com densa pontuação umbilicada rasa. Hipopígio com margem posterior reta. Ápice acuminado. Medidas relativas: gáster C 60(+2 ovip.); T1 C 32; T7+8 13:12.

Macho. Comprimento: 3,1-4,2 mm (Lectótipo: 3,2 mm)

Essencialmente igual à fêmea, exceto por apresentar ápice do gáster não acuminado e pela pilosidade sensorial ventral mais longa e conspícua nos segmentos funiculares da antena.

Variações. As partes negras do corpo podem ser mais ou menos extensas. A faixa mediana sem pontos do escutelo pode ser menos conspícua. A carena frenal pode ser ligeiramente ondulada, mas nunca emarginada ou bilobada.

Distribuição. México*, El Salvador*, Panamá*, Colômbia*, Guiana* e Brasil (AM* e PA).

Hospedeiro. Desconhecido.

Comentários. Esta espécie apresenta mandíbula alongada e unidentada (Fig. 18), projeção interantenal indicada por uma suave elevação da superfície do escrobo, carena frenal com margem arredondada (Fig. 19), carena epicnemial reta na porção mediano-ventral, escutelo com faixa mediana sem pontuações (Fig. 19); o $1^{\circ}$ e o $4^{\circ}$ dentes da margem inferior do metafêmur maiores que os demais. Sobre a sinonímia de Chalcis belfragei sob Brachymeria dorsalis, proposta por Bouček (1992), veja discussão em $C$. belfragei comb. nov., acima.

Material examinado. Lectótipo: macho, com as etiquetas 'Braz, Santarem', 'Lectotype/Bouček 1991', 'Santarem', 'Chalcis dorsalis, Walker/stood under this name...', 'B.M. Type Hym 5.457' e 'Lectotype, Brachymeria dorsalis Walker macho Boucek, 1991' (BMNH). Material não-tipo. MÉXICO, Veracruz: 1 fêmea, Sontecomapan, U. Mex. Biol. Res., 19.VI.1969, 400 pés (W. R. M. Manson) (CNCI); Oaxaca: 1 macho, Temascal, 24.IX.1963 (D. H. Janzen) (EMEC); Chiapas: 1 fêmea, L. Montebelo, 13.VI.1969 (W. R. M. Manson) (CNCI). EL SALVADOR, San Salvador: 1 macho, San Salvador, 8.VII.1963 (D. Q. Cavagnaro \& M. E. Irwin) (CAS). PANAMÁ: 1 fêmea, Cabima, 18.V.1911 (A. Busck) (MCZH). COLÔMBIA, Cundinamarca: 1 fêmea, Finca Bella Vista nr. Sasaima, 7.VI.1965 (P. R \& D. L. Craig) (CAS); 1 fêmea, ibidem, 4.VI.1965 (CAS). GUIANA: 1 fêmea, Bartica, 17.V.1901 (USMN); 2 fêmeas, 1 macho, Kartabo, VII-VIII.1920 (W. M. Wheeler) (MCZH). BRASIL, Amazonas: 1 fêmea, Humaitá, 15-17.IX.1990, arm suspensa (R. Constantino) (MPEG); Pará: 1 fêmea, Santarém Novo, Faz. Jaburai, 7-9.I.1993, arm. suspensa 2,5 m (J. Dias) (MPEG); 1 macho, Carajás, Serra Norte, Azul, Serraria, 20-24.VI.1985, arm. Malaise (F. F. Ramos) (MPEG). 


\section{Ceyxia flaviscapus Girault, 1911}

(Figs. 20-23)

Ceyxia flaviscapus Girault, 1911: 383, 384 [Paraguai: Assunção].

Ceyxia paraguayensis Girault, 1911: 385 [Paraguai: Assunção]. sin. nov.

Ceyxia fumipennis Giraut, 1911: 383, 384 [Paraguai: Assunção]. Bouček 1992: 89 (desig. de sinonímia).

Chalcis (Ceyxia) flaviscapus: Girault 1913: 67.

Brachymeria (Brachymeria) flaviscapus: De Santis 1979a: 58.

Brachymeria (Brachymeria) fumipennis: De Santis 1979a: 8, 56, 58

Brachymeria (Brachymeria) paraguayensis: De Santis 1979a: 61.

Brachymeria flaviscapus: Bouček 1992: 89; Arias \& Delvare 2003: 129.

Brachymeria paraguayensis: Bouček 1992: 89; Arias \& Delvare 2003: 130

Diagnose. Projeção interantenal laminar, usualmente com um tubérculo apical (Fig. 20); OOL menor que DOA; mandíbula bidentada, dentes apicais (Fig. 20); carena frenal bilobada a emarginada (Fig. 22, 23); ápice da metatíbia rômbico, sem espinho distinto (Fig. 21); gáster no máximo 1,2x mais longo que o mesossoma.

Descrição. Fêmea. Comprimento 4,4-5,8 mm.

Coloração. Negra, exceto: olho e ocelos castanhos; escapo, tégula, perna anterior, 1/4 apical do fêmur médio, tíbia média, face ventral da metacoxa, manchas basal e apical da face externa do metafêmur, metatíbia e tarsos amarelos. Asas ligeiramente enegrecidas. Pilosidade do tronco branca.

Cabeça. Pilosidade 2x mais longa que o diâmetro dos umbílicos, pouco mais esparsa na área ao redor dos ocelos. Umbílicos da fronte e porção anterior do vértice com $0,3 \mathrm{x}$ o DOA, na porção posterior do vértice irregulares; interstício coriáceo, cerca de $0,5 \mathrm{x}$ o diâmetro dos umbílicos. Face inferior com umbílicos inconspícuos, quase lisa. Vértice com perfil arredondado. Face ligeiramente convexa. Ocelo anterior situado fora do escrobo. Escrobo com margem carenada até 0,6x de sua altura; superfície interna lisa. Projeção interantenal muito desenvolvida, com um tubérculo apical (Fig. 20). Mandíbulas bidentadas, dente superior distintamente menor que o inferior e afastado do ápice (Fig. 20). Carena pós-orbital encontra a carena genal pouca acima do nível ocular inferior. Carena occipital conspícua até o forâmen occipital. Antenas robustas, estreitadas no ápice; escapo não atingindo a margem do ocelo anterior; F1 obcônico. Medidas relativas: C:A:L 22:32:52; FV 21; LS 16; EPE 6; ETC 5; EM 6; FO 16; DOA 6; APL 4; OOL 3; POL 8; olho A:L:LF 29:21:15; escapo antenal C:L 15:3; pedicelo 3:3; anellus C 1; F1 5:4; F2-F3 4:5; F4-F6 4:6; F7 4:5; clava 8:5.

Mesossoma. Dorso convexo, pilosidade cerca de 2x mais longa que o diâmetro dos umbílicos, no escutelo mais que $2 \mathrm{x}$ esse diâmetro. Umbílicos do pronoto, margem anterior do lobo mediano do mesoscuto e escápulas com $0,4 \mathrm{x}$ o DOA; no restante do lobo mediano cerca de $0,5 \mathrm{x}$ o DOA e no escutelo 0,9x o DOA; interstício coriáceo, menor que 0,5 x o diâmetro dos umbílicos. Carena pronotal ausente na porção medianodorsal por 0,8x do FV. Umbílicos da margem posterior do pronoto mal definidos, formando uma carena conspícua em suas margens anteriores. Porção superior da lateral do pronoto coriácea, sulco transversal normalmente interrompido por uma carena oblíqua. Escutelo convexo; carena frenal muito desenvolvida, projetada medianamente bilobada (Fig. 22). Área frenal com quatro a seis carenas transversais delicadas, interstício inconspicuamente esculturado. Mesepisterno com interstício liso. Carena epicnemial bilobada na porção medianoventral. Depressão femoral com algumas carenas transversais curtas e inconspícuas acima da transepimeral, quase toda lisa. Epímero superior inconspicuamente estriado. Asa anterior com a dobra basal com duas a três fileiras de cerdas, a dobra cubital com uma fileira; linha de cerdas subcubital presente abaixo da dobra cubital; célula basal normalmente com algumas cerdas próximo à dobra basal, eventualmente com uma curta fileira de cerdas que acompanham a submarginal. Metafêmur (Fig. 21) com seis a oito dentes na margem inferior, o basal largo e forte, o $4^{\circ}$ e o $5^{\circ}$ os maiores; pilosidade externa pouco mais longa que $2 \mathrm{x}$ a distância entre os pontos, estes mais grosseiros na porção inferior. Ápice da metatíbia rômbico, não formando o espinho apical. Medidas relativas: mesossoma C:L 63:47; pronoto C 13; mesoscuto C 47; escutelo C:L 25:26; asa C:L 117:45, SM45, M24, PM 7, ES 3; metacoxa C 24; metafêmur C:L 44:22.

Metassoma. Pecíolo dorsalmente transverso. T1 cerca de $0,5 \mathrm{x}$ o comprimento do gáster; liso e com pontuação pilosa latero-dorsal, pontuado nas laterais, próximo à margem posterior; margem porterior dorsal reta. T2 com margem reta, em T3-5 ligeiramente côncava. T2-T5 coriáceos, com densa pontuação pilosa nas laterais; no dorso representada por uma fileira de pontos. T6 com pontuação umbilicada rasa. Hipopígio com o ápice emarginado medianamente. Ápice acuminado. Medidas relativas: gáster C 60 (+ 2 ovip.); T1 C 31; T7+8 2:4.

Macho. Comprimento 5,1 mm.

Semelhante à fêmea, exceto por apresentar ápice do gáster não acuminado e presença de cerdas sensorias mais longos ao menos na face ventral dos F2-F3.

Variações. O dente superior da mandíbula pode ser vestigial, mas normalmente é conspícuo. O tubérculo apical da projeção interantenal pode ser reduzido e a projeção laminar. A carena frenal pode ser muito desenvolvida, projetada posteriormente e bilobada ou pode ser um pouco mais curta e emarginada (Figs. 22 e 23). A pontuação da lateral do T1 pode estar ausente.

Distribuição. EL Salvador, Panamá, Trinidad, Equador, Peru, Brasil*(RO, MS, SP e SC), Bolívia* e Paraguai.

Hospedeiros. Um exemplar de Trinidad emergiu de Trypoxylum nitidum Smith.

Comentários. C. flaviscapus é semelhante a $C$. ventrispinosa, principalmente, quanto à presença do tubérculo na projeção interantenal (Fig. 20), que pode estar ausente na primeira e, neste caso, o ápice da projeção é laminar. A segunda espécie apresenta a carena da margem do escrobo se entendendo sobre a área parescrobal (eventualmente inconspícua) e o espinho da metatíbia agudo (ausente em $C$. 

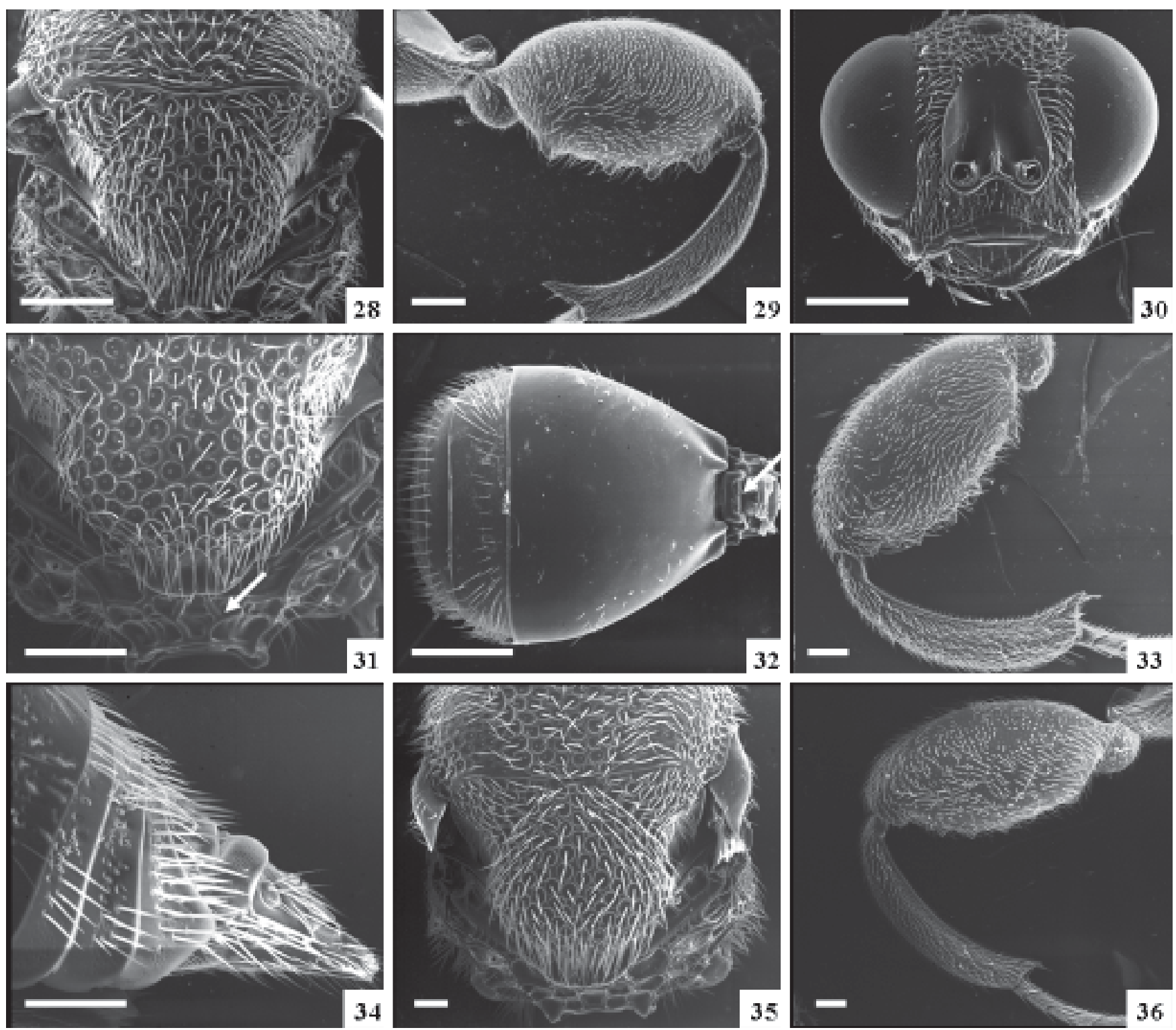

Figs. 28-36. 28-29. Ceyxia longispina sp. nov., fêmea: 28, escutelo dorsal; 29, metafêmur e metatíbia. 30-32. Ceyxia nigropetiolata sp. nov., macho: 30, cabeça frontal; 31, escutelo e propódeo dorsal, indicando aréola pentagonal; 32, metassoma dorsal, indicando a porção do pecíolo visível dorsalmente. 33-34. Ceyxia parvidentata sp. nov., fêmea: 33, metafêmur e metatíbia; 34, ápice do metassoma lateral. 35-36. Ceyxia perparva sp. nov., fêmea: 35, escutelo dorsal; 36, metafêmur e metatíbia. Escala $250 \mu \mathrm{m}$.

flaviscapus, Fig. 21). As características mais marcantes de $C$. flaviscapus são: mandíbula bidentada; projeção interantenal muito desenvolvida (Fig. 20); ápice da metatíbia sem espinho distinto. Neste estudo constatou-se que as diferenças encontradas nos tipos de B. paraguayensis e de C. flaviscapus são apenas variações da mesma espécie, assim é proposta sinonímia da primeira sob a segunda. Esta espécie também é semelhante a $C$. concitator comb. nov., conforme discutido anteriormente, mas tem distribuição predominantemente mais ao sul. Os exemplares tipos de Ceyxia paraguayensis depositados no ZMBH, fêmea e macho, apesar de portarem as etiquetas de lectótipo e paralectótipo, respectivamente, não haviam sido designados. Assim, este ato é aqui efetivado.
Material examinado. Tipos. Ceyxia flaviscapus: fêmea (holótipo), com as etiquetas 'Assuncion, Paraguay, 7.V.05', '31934', 'Ceyxia flaviscapus Girault female', 'ex col Girault', 'type', 'Zool. Mus. Berlin', 'Holotype fêmea, Ceyxia flaviscapus Girault, 1911 Bouček, 1971' (sem cabeça, pernas anteriores e médias direitas, e tarsos posteriores) (ZMHB). Ceyxia fumipennis: fêmea (holótipo), com as etiquetas 'Assuncion, Paraguay, 19.iv.05, Gerten, JDAnisits', '31933', 'SM ... 1003', 'Ceyxia fumipennis Girault female' 'ex col Girault' 'Type' 'Zool. Mus. Berlin' 'Holotype female, Ceyxia fumipennis Girault, 1911 Bouček, 1971' (sem antena esquerda, e flagelo esquerdo) (ZMHB). Ceyxia paraguaiensis: 1 fêmea (lectótipo, aqui designado) e 1 macho (paralectótipo, aqui designado) (montados em micro-alfinetes e presos à mesma base), com as etiquetas 'Assuncion, Paraguay, 10.VIII. 05, J. D. Anisits' 'no. 541910 /VIII 05' '31935' '54' 'Ceyxia paraguayensis Girault 2 'ex col Girault' 'Type' 'Zool. Mus. Berlin' 'Ceyxia paraguayensis Girault, 1911 Bouček, 1971' (ZMHB); o exemplar fêmea 
possui uma etiqueta vermelha escrito 'Lectotypus fêmea/Bouček, 1971' e o macho 'Paralectotypus/Bouček, 1971'. Material não-tipo: EL SALVADOR, La Libertad: 1 fêmea, Quezaltepeque, 19.VI.1963 (D.Q. Canagnaro \& M.E. Irwin) (CAS). PANAMÁ, Zona do Canal: 1 fêmea, Barro Colorado, I.1947 (N. L. H. Krauss) (USMN); 1 macho. ibidem, 02.VIII.1980 (Henk Wolda) (UCDC); 1 macho, ibidem, V.1939 (J. Zetek) (USMN); 1 fêmea, ibidem, 12.II.1955 (Carl Rettenmair) (SEMC); 1 fêmea, ibidem, 14.V.1939 (SEMC); 1 fêmea, 1 macho, Ancon, 17.VII.1923 (J.Zetec) (USNM). TRINIDAD: 1 fêmea, Saint Augustine, 10.IV.1950, ex Trypoxylon nitidum Smith 'from old nest of 'Polistes canadensis (L.) (E. Mec. Callan) (USMN). EQUADOR, Napo: 1 fêmea, Coca VI.1986 (G. Onore); Sucumbios: 1 fêmea, R. Napo, Sacha Lodge, 220, 04-14.III.1994 (Peter Hibbs) (QCAZ). PERU, Huanuco: 1 fêmea, Mozon Valley, Tingo Maria, 26.X.1954 (E. I. Schlinger \& E. S. Ross) (CAS). BRASIL, Roraima: 3 fêmeas, Ilha de Maracá, Rio Uraricoera, 21-30.XI.1987 e 1-4.III.1988, arm. Malaise (J. A. Rafael) (INPA). Amapá: 1 fêmea, Porto Platon, IX.1957 (J. Lane) (MZSP). Amazonas: 1 macho, Manaus, Campus UFAM, 26.VIII.1978, arm. Malaise (J. A. Rafael) (INPA); 1 fêmea, ibidem, 09.IX.1978 (INPA); 1 fêmea, ibidem, 29.V.1979 (INPA); 1 fêmea, Manaus, Reserva Ducke, 18.I.1982 (INPA); 1 macho, ibidem, 0617.VII.1992, arm. adesiva, 18 a 20 m (Vidal \& Vidal) (INPA); 1 fêmea, Manaus, ZF3 Km 23., Res. 1112, 14.I.1986, arm. Malaise (B. Klein) (INPA); 1 fêmea, Manaus, Reserva Campina, 2.XII.1981 (Rafael \& Binda) (INPA); 1 fêmea, P. das Laranjeiras, 14.VIII.1981 (Jorge Arias) (INPA); Pará: 1 macho, Rio Xingu Camp ca. $60 \mathrm{~km} \mathrm{S.} \mathrm{Altamira,}$ 5272'W, 339' S, 2-8.X.1986, arm. Malaise (P. Spangler \& O. Flint) (USMN); 1 fêmea, Santarém Curuá, 01.XII.1997, arm. Malaise (A. R. Lisboa) (DCBU); 1 fêmea, Rio Mapuera, acima Rio Assumpção, 04.VI.1986, arm. Malaise (INPA); 1 fêmea, Serra Norte, Est. Manganês, 12.VI.1983, arm. suspensa 20 m (MPEG); Rondônia: 1 fêmea, Rio Guaporé, "Oposite mouth of rio Baures" (Bolívia), 1-5.X.1964 (Bouseman \& Lussenhop) (AMNH); Mato Grosso: 1 fêmea, Chapada dos Guimarães, Fazenda Buriti, 18.XI.1982 (Marcia Zanute, W. Overal) (MPEG); Mato Grosso do Sul: 1 fêmea, Corumbá, Passo da Lontra, 0812.XI.1993 (L. Joaquim \& L. Reis) (DCBU); Minas Gerais: 1 fêmea, Belo Horizonte, Estação Ecológica da UFMG, 1952'S,4358W 830 m, 1.VI.1996, arm. Malaise (J.C.R. Fontenelle) (UFMG); São Paulo: 3 fêmeas, Araçatuba, X.1961 (J. Lane \& Rabello) (MZSP); 2 fêmeas, Barueri, 30.VII.1960 (K. Lenko) (MZSP), 2 fêmeas, ibidem, 27.VIII.1960 (MZSP); 1 fêmea, ibidem, 18.II.1967 (MZSP); 1 fêmea, São Carlos, Faz. Canchim, mata, 09.X.1996 (T. M. Guerra); 1 fêmea, cerrado, 28.II.1990, arm Moericke (N. W.Perioto) (UFES); 1 fêmea, Piraqueaçu, 08.I.1987, bandeja amarela (Expedição Inst. Biol) (IBSP). Rio de Janeiro: 1 fêmea, Itatiaia, 14.VIII.1978 (H.F.Berla) (MNRJ); 1 fêmea, ibidem, 8.I.1946 (J. F. Zikan) (FIOC); 1 fêmea, Nova Iguaçu, Res. Biol. Tinguá, 22³4'38'’ $843^{\circ} 26^{\circ} 09^{\circ} \mathrm{W}, 08-11$. III.2002, arm. Malaise trilha 1 (S. T .P Amarante) (MZSP); Paraná: 1 fêmea, Morretes, IAPAR, 15-22.X.1984, arm. Malaise (CIIF) (DZUP); Santa Catarina: 1 fêmea, Nova Teutonia, 27²11'B52²3'L 1.VI.1965 (Fritz Plaumann) (LACM). BOLÍVIA, Santa Cruz: 3 fêmeas, Roboré, X.1959 (SEMC). Localidade desconhecida: 1 fêmea, Brasil, Igarapé-assú, 8.V.1919 (Parish) (IHNS).

\section{Ceyxia fusidentata sp. nov.} (Figs. 50-53)

Diagnose. Projeção interantenal indicada por uma saliência pilosa da superfície do escrobo (Fig. 50); metafêmur com cinco a sete dentes ventrais, os dois apicais fundidos em uma lâmina (Fig. 53); bainha do ovipositor com ápice acuminado (Fig. 52).

Descrição. Fêmea. Comprimento: 5,3-5,8 mm. (Holótipo: $5,6 \mathrm{~mm})$.

Coloração. Negra, exceto: dorso do mesossoma, face ventral da metacoxa e metade basal do metafêmur marrons avermelhados; olho e ocelo castanhos; tégula, pernas anteriores e médias, e mancha apical do metafêmur amarelos; asa hialina; pilosidade branca.

Cabeça. Pilosidade tão longa quanto 2x o diâmetro dos umbílicos, pouco mais esparsa na área ao redor dos ocelos e face; densa nas têmporas. Umbílicos da fronte e porção anterior do vértice com cerca de $0,25 \mathrm{x}$ do DOA, na porção posterior do vértice umbílicos irregulares; interstício coriáceo. Face inferior com pontuação diminuta irregular, interstício coriáceo. Vértice com perfil arredondado. Face com perfil convexo. Ocelo anterior não toca a margem do escrobo (Fig. 50) este com margem carenada até $0,75 \mathrm{x}$ de sua altura; parte inferior da superfície interna lisa e a superior coriácea. Projeção interantenal indicada por uma saliência pilosa da superfície do escrobo (Fig. 50). Mandíbula unidentada. Carena pós-orbital encontra a carena genal acima do nível ocular inferior. Carena escrobo-malar evidente. Antena afilada no ápice; escapo não ultrapassa a margem do ocelo anterior. Medidas relativas: $\mathrm{C}: \mathrm{A}: \mathrm{L}$ 30:45:72; FV 33; LS 20; EPE 7; ETC 7; EM 10; FO 20;DOA 8; APL; 5; OOL 5; POL 13; olho A:L:LF 47:32:25; antena: escapo C:L 21:5; pedicelo 4:5; anellus C 2; F1 7:6, F2 6:7; F3,5 e 6 6:8; F4 5:9; F7 5:7; clava 14:8.

Mesossoma. Dorso convexo, pilosidade cerca de 2x o diâmetro dos umbílicos. Umbílicos do pronoto, margem anterior do lobo mediano do mesoscuto e escápula com $0,3 \mathrm{x}$ DOA; no restante do lobo mediano cerca de $0,4 \mathrm{x}$ o DOA e no escutelo atingindo $0,5 \mathrm{x}$ o DOA interstício coriáceo, no pronoto menor que 0,4 x o diâmetro dos umbílicos. Carena pronotal ausente na porção mediano-dorsal por 0,9x do FV. Umbílicos da margem posterior do pronoto irregulares, suas margens anteriores formam uma carena evidente. Porção superior da lateral do pronoto coriácea, sulco transversal evidente. Escutelo convexo; carena frenal emarginada (Fig. 51). Área frenal coriácea com três carenas transversais inconspícuas. Mesepisterno com interstício liso. Carena epicnemial bilobada na porção mediano-ventral. Depressão femoral com carenas interrompidas acima da transepimeral. Epímero superior rugoso. Propódeo areolado-rugoso com aréola mediana pentagonal elevada na parte mediana do propódeo. Asa anterior com dobra basal indicada por duas fileiras de cerdas; dobra cubital indicada por uma fileira de cerdas; célula basal glabra, linha de cerdas subcubital presente abaixo da dobra cubital. Metafêmur com cinco dentes ventrais desenvolvidos, os dois últimos apicais fundidos em uma lâmina (Fig. 53). Metatíbia com espinho apical, curto, levemente curvo e agudo (Fig. 53). Medidas relativas: C:L 85:65; mesoscuto C 55; escutelo 65:90; asas 190:65; SM 75; M 38; PM 11; ES 5; metacoxa C 60; metafêmur: C:L 75:40.

Metassoma. Pecíolo visível dorsalmente com duas carenas transversais; T1 liso com pouca pilosidade látero-dorsal e margem posterior reta; T2-T5 lisos com pouca pilosidade láterodorsal e margem posterior levemente côncava; T6-T7 coriáceos com pilosidade látero-dorsal e margem convexa; hipopígio reto com lobo mediano não proeminente; bainha do ovipositor com ápice acuminado (Fig. 52). Gáter acuminado. Medidas relativas: gáster C:L 110:55 (+ ovipositor 6); T1 C 55; T7+T8 8:3. 
Etimologia. Epíteto específico em referência aos dois últimos dentes distais do metafêmur serem fundidos.

Variações. O gáster e pernas posteriores podem variar de marrom claro a marrom escuro, o número de dentes ventrais do metafêmur pode variar de cinco a seis, o espinho da metatíbia pode ser longo e agudo ou mais curto e rômbico.

\section{Distribuição. Brasil (AM)}

Hospedeiro. Deconhecido.

Comentários. Foram estudados 3 exemplares, mas apenas dois foram incluidos na série tipo. O exemplar coletado em 25.VI.1985 apresenta seis dentes ventrais no metafêmur, e o espinho apical da metatíbia mais longo e agudo. Como o número de exemplares é pequeno e não se pode assegurar se estas variações são inter ou intra-específicas, optou-se, por excluir esse exemplar da série tipo. Só com o estudo de espécimes adicionais esta dúvida poderá ser sanada. Esta espécie também se assemelha a C. belfragei comb. nov. quanto à coloração do dorso do mesossoma, espinho da metatíbia, posição do ocelo em relação ao escrobo e pecíolo visível dorsalmente, porém, C. fusidentata sp. nov. difere pela mandíbula unidentada e bainha do ovipositor com ápice acuminado (Fig 52), além da distribuição geográfica.

Material examinado. Holótipo fêmea, com a etiqueta 'BRA[SIL]AM[AZONAS]- Manaus zf3-km23-res. 1208 8.XI.1984 Armad[ilha] Malaise Bert Klein, col.' (INPA). Parátipos. 1 fêmea, ibidem, 7.I.1986 (INPA); Outro exemplar estudado:1 fêmea, ibidem, 25.VI.1985 (INPA).

\section{Ceyxia gibbosa sp. nov.}

(Figs. 54-57)

Diagnose. Projeção interantenal indicada por uma saliência pilosa da superfície do escrobo (Fig. 54); mandíbula bidentada; escutelo giboso; carena frenal bilobada (Fig. 55); metafêmur com nove dentes ventrais reduzidos (Fig. 57); bainha do ovipositor com ápice truncado (Fig. 56).

\section{Descrição. Fêmea. Comprimento: 6 mm (Holótipo)}

Coloração. Negra, exceto: olho e ocelo castanhos; dorso do mesossoma marrom-avermelhado; tégula, $0,75 \mathrm{x}$ basais do escapo, metade apical da tíbia anterior e média, mancha basal e apical do metafêmur e tarso amarelos; asa esfumaçada; pilosidade branca.

Cabeça. Pilosidade tão longa quanto 2,5x o diâmetro dos umbílicos, mais esparsa ao redor dos ocelos e muito densa na face inferior e têmporas. Umbílicos fronte e porção anterior do vértice com cerca de $0,25 \mathrm{x}$ do DOA, na porção posterior do vértice umbílicos irregulares; interstício coriáceo. Face inferior com pontuação irregular, interstício coriáceo. Vértice com perfil arredondado. Face com perfil convexo. Ocelo anterior não toca a margem do escrobo; este com margem carenada até $0,75 x$ de sua altura; superfície interna com parte inferior lisa e superior coriácea. Projeção interantenal indicada por uma saliência pilosa da superfície do escrobo (Fig. 54). Mandíbula bidentada, dente superior vestigial e afastado do ápice, o inferior longo e agudo. Carena pós-orbital encontra a carena genal acima do nível ocular inferior. Carena escrobo-malar evidente. Antena afilada no ápice; escapo não ultrapassa a margem do ocelo anterior. Medidas relativas: C:A:L 30:45:79; FV 25; LS 25; EPE 6; ETC 8; EM 10; FO 30; DOA 8; APL 5; OOL 6; POL 12; olho A:L:LF 43:30:24; antena: escapo C:L 23:9; pedicelo 5:5; anellus C 4 ; F1-F3 7:8; F4 e F6 7:10; F5 e F7 6:10; clava 14:9.

Mesossoma. Dorso convexo, pilosidade cerca de 2x o diâmetro dos umbílicos. Umbílicos do pronoto, margem anterior do lobo mediano do mesoscuto e escápula com $0,4 \mathrm{x}$ o DOA; no restante do lobo mediano cerca de $0,5 \mathrm{x}$ o DOA e no escutelo atingindo 0,6x o DOA, interstício coriáceo. Carena pronotal ausente na porção mediano-dorsal pela mesma distância do FV. Umbílicos da margem posterior do pronoto irregulares, suas margens anteriores formam uma carena anterior evidente. Porção superior da lateral do pronoto coriácea, sulco transversal evidente e interrompido por uma carena mediana. Escutelo giboso; carena frenal bilobada (Fig. 55). Área frenal coriácea com três carenas transversais inconspícuas. Mesepisterno com interstício liso. Carena epicnemial emarginada na porção mediano-ventral. Depressão femoral com uma série de carenas acima da transepimeral. Epímero superior liso. Propódeo areolado-rugoso com aréola mediana pentagonal projetada na região mediana. Asa anterior com a dobra basal indicada por duas fileiras de cerdas; dobra cubital indicada por uma fileira de cerdas; célula basal glabra, linha de cerdas subcubital presente abaixo da dobra cubital. Metafêmur com nove dentes ventrais pequenos (Fig. 57). Metatíbia com espinho curto, curvo e agudo (Fig. 57). Medidas relativas: mesossoma $\mathrm{C}: \mathrm{L}$ 100:70; mesoscuto $\mathrm{C}$ 65; escutelo 90:100; asas 195: 65; SM 70; M 42; PM 10; ES 5; metacoxa C 45; metafêmur: C:L 70:35.

Metassoma. Pecíolo visível dorsalmente; T1 liso, com pilosidade látero-dorsal e margem posterior reta; T2-T5 coriáceos, com pilosidade látero-dorsal e margem posterior ligeiramente côncava; T6-T7 coriáceos, com pilosidade láterodorsal e margem posterior convexa; hipopígio com lobo mediano proeminente; bainha do ovipositor com ápice truncado (Fig. 56). Ápice acuminado. Medidas relativas: gáster C:L 110:55 (+ ovipositor 5); T1 C 60; T7+T8 9:4.

Etimologia. Epíteto específico em referência ao perfil do escutelo.

Distribuição. Brasil (ES).

Hospedeiros. Deconhecidos.

Comentários. Esta espécie é próxima a C. fusidentata $\mathbf{s p . ~}$ nov., apresentando coloração do dorso do mesossoma, posição do ocelo em relação ao escrobo e carena frenal semelhantes, mas se diferenciam através do perfil do escutelo, número e padrão de dentes ventrais do metafêmur. As duas espécies, também apresentam distribuição geográfica bastante distinta, sendo $B$. fusidentata sp. nov. restrita a região Amazônica e $C$. gibbosa sp. nov. restrita ao Espírito Santo. 
Material examinado. Holótipo fêmea, com a etiqueta 'BRASILES-S[anta] M[aria] Jetibá, Faz[enda] Clarindo Krüger 2004'27,9's $40^{\circ} 44^{\prime}$ 51,3"O 29.xi-06.xiii.[20]02, malaise B5 MTTavares e eq[uipe] col.' (UFES).

\section{Ceyxia laminata sp. nov.}

(Fig. 58)

Diagnose. Projeção interantenal forma uma lâmina alta e pilosa (Fig. 58); com carena horizontal laminar acima da depressão foraminal; F2-7 mais largos que longos; mandíbula bidentada; escutelo plano e largo; carena frenal larga e bilobada.

Descrição. Fêmea. Comprimento: 6,8-7,9 mm (Holótipo: 7,9 $\mathrm{mm})$.

Coloração. Negra exceto: olho e ocelo castanhos; três quartos basais da parte ventral do escapo, tégula, tíbia, metade apical do pró-fêmur e mesofêmur, e mancha apical e basal do metafêmur amarelos; asa esfumaçada; pilosidade branca.

Cabeça. Pilosidade tão longa quanto 2x o diâmetro dos umbílicos, mais esparsa ao redor dos ocelos e face inferior. Umbílicos da fronte e porção anterior do vértice com cerca de $0,2 x$ a $0,25 x$ o DOA, na porção posterior do vértice umbílicos regulares; interstício coriáceo. Face inferior com área mediana elevada, com pontuação esparsa acima do clípeo; interstício liso. Vértice com perfil arredondado. Face com perfil convexo. Ocelo anterior toca a margem do escrobo; este com margens sinuosas, refletidas lateralmente e carenadas até $0,75 \mathrm{x}$ de sua altura; superfície interna lisa. Projeção interantenal forma uma lâmina alta e pilosa com uma pequena quilha na parte superior (Fig. 58). Mandíbula bidentada, dente superior evidente. Carena pós-orbital encontra a carena genal no nível ocular inferior. Carena horizontal laminar acima da depressão foraminal. Carena escrobo-malar completa e incosnpícua próximo à carena malar. Antena afilada no ápice; escapo ultrapassa a margem do ocelo anterior. Medidas relativas: C:A:L 40:60:105; FV 50; LS 30; EPE 7; ETC 8: EM 13; FO 35; DOA 10; APL 5; OOL 6; POL 17; olho A:L:LF 50:40:28; antena: escapo C:L 40:10; pedicelo 9:6; anellus C 3; F1 12:9; F2 8:11; F3 8:12; F4 7:14; F5 9:14; F6 9:15; F7 8:15; clava 18:13.

Mesossoma. Dorso plano; pilosidade cerca de 2x o diâmetro dos umbílicos, no escutelo mais que $2 \mathrm{x}$ esta medida. Umbílicos do pronoto, margem anterior do lobo mediano do mesoscuto e escápula com $0,25 x$ o DOA; no restante do lobo mediano e escutelo cerca de $0,4 x$ o DOA; interstício coriáceo, no pronoto menor que $0,5 \mathrm{x}$ o diâmetro dos umbílicos. Carena pronotal ausente na porção mediano-dorsal por 0,8x do FV. Umbílicos da margem posterior do pronoto irregulares, suas margens anteriores formam uma carena anterior evidente. Porção superior da lateral do pronoto coriácea, sulco transversal evidente com uma série de carenas intermediárias. Escutelo plano; carena frenal bilobada e ampla. Área frenal rugosa com quatro carenas transversais. Mesepisterno com interstício liso. Carena epicnemial côncava na porção medianoventral. Depressão femoral com algumas estrias na parte inferior. Epímero superior liso. Propódeo areolado-rugoso com aréola mediana pentagonal. Asa anterior com a dobra basal glabra, dobra cubital glabra; célula basal glabra, cerdas subcubital ausente abaixo da dobra cubital. Metafêmur com sete dentes ventrais, o basal muito curto, os demais quase do mesmo tamanho. Metatíbia com espinho longo e agudo. Medidas relativas: mesossoma C:L 130:95, mesoscuto C 95; escutelo 110:135; asas: 230:80; SM 70; M 40: PM 10; ES 8; metacoxa C 60; metafêmur C:L 90:53.

Metassoma. Pecíolo não visível dorsalmente; T1 liso, com pouca pilosidade látero-dorsal, margem posterior reta; T2-T5 lisos, com pilosidade látero-dorsal e margem posterior ligeiramente côncava; T6-T7 coriáceos com pilosidade láterodorsal e margem convexa; hipopígio com lobo mediano reto. Ápice acuminado. Medidas relativas: gáster C:L 145:75 (+ ovipositor 5); T1 C 70; T7+T8 15:10.

Macho. Semelhante à fêmea exceto por apresentar gáster menor e truncado.

Etimologia. Epíteto específico em referência à projeção interantenal laminar.

Distribuição. Panamá e Brasil (RR).

Hospedeiros. O holótipo emergiu de ninho de Auplopus femoratus (Fab.) (Pompilidae).

Comentários. $C$. laminata sp. nov. é semelhante a $C$. longiarticulata sp. nov. e C. longispina sp. nov. por apresentar área elevada na região mediana da face inferior, mas pode ser diferenciada através da projeção interantenal laminar (Fig. 58). De $C$. longiarticulata sp. nov. também se diferencia por F2-F3 mais largos que longos.

Material examinado. Holótipo fêmea, com as etiquetas 'Lion Hill CZ Panama VI.27 1982 k206' 'L. S. Kimsey' 'reared from nest of Auplopus femoratus (F.) (Pompilidae)' 'Brachymeria F Bouček det. 1984' (UCDC). Parátipos. 1 macho, ibidem, 30.VI.1982; BRASIL, Roraima: 1 fêmea, Ilha de Maracá, Rio Uraricoera, 2-13.V.1987 (J. A. Rafael, J. E. B. Brasil, L. S. Aquino) (INPA); Amazonas: 1 fêmea, Manaus, ZF3 km23 Res. 1112, 04.II.1986 (B. Klein) (INPA).

\section{Ceyxia laticlipeata sp. nov.}

(Figs. 24-25)

Diagnose. Clípeo alargado (Fig. 24); cavidade da fossa oral muito ampla; mandíbula unidentada com dente curvo; metafêmur com pontuação rasa na face externa e dentes ventrais desenvolvidos, os dois apicais fundidos em uma lâmina curva (Fig. 25); asas enegrecidas.

Descrição. Fêmea. Comprimento: 6,5-7,5 mm (Holótipo: 6,6 $\mathrm{mm})$.

Coloração. Negra, exceto: olho e ocelo castanhos; tégula, escapo, metade apical do pró-fêmur e mesofêmur, mancha apical e basal da face externa do metafêmur e tíbia, amarelos; asa enegrecida; pilosidade branca. 

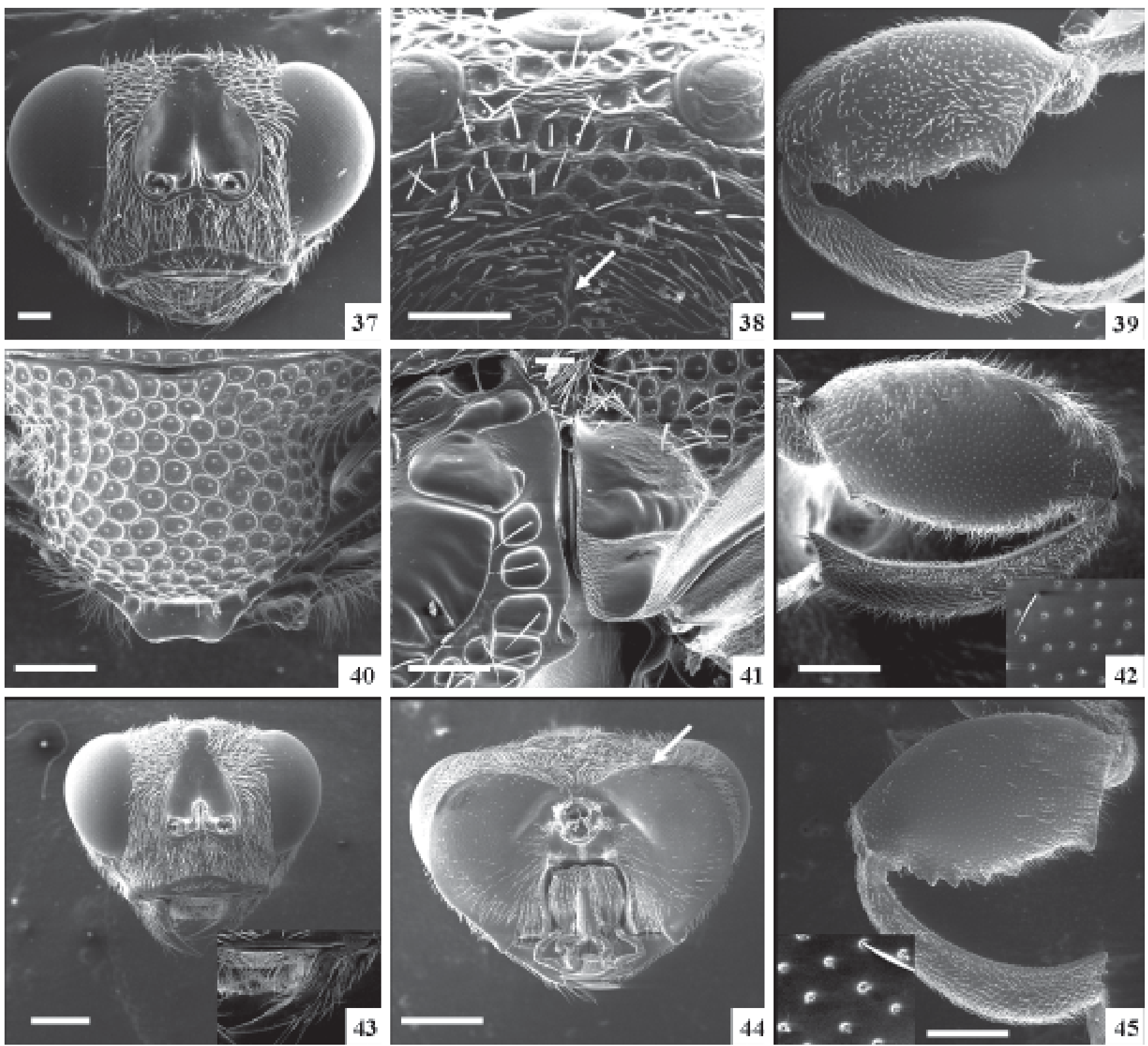

Figs. 37-45. 37-39. Ceyxia pseudovillosa sp. nov., fêmea: 37, cabeça frontal; 38, cabeça posterior, indicando carena longitudinal acima do forâmen magno; 39, metafêmur e metatíbia. 40-42. Ceyxia ventrispinosa stat. rev., fêmea: 40, escutelo dorsal; 41, mesopleura e lateral do pronoto; 42, metafêmur, metatíbia e detalhe da superfície do metafêmur. 43-45. Ceyxia villosa comb. nov., fêmea: 43, cabeça frontal e detalhe da mandíbula; 44, Cabeça posterior e seta indicando carena occipital; 45; metafêmur, metatíbia e detalhe da superfície do metafêmur. Escala 250 um.

Cabeça. Pilosidade 2x o diâmetro dos umbílicos, mais esparsa e fina ao redor dos ocelos. Umbílicos da fronte e porção anterior do vértice com cerca de $0,25 x$ do DOA, na porção posterior do vértice umbílicos irregulares; interstício coriáceo. Face inferior com pontuação irregular, interstício liso. Vértice com perfil arredondado. Face com perfil convexo. Ocelo anterior não toca a margem do escrobo; que é carenada até quase sua altura, superfície interna lisa. Projeção interantenal como uma pequena saliência pilosa da superfície do escrobo (Fig. 24). Clípeo alargado. Mandíbula unidentada, com dente curvo. Carena pós-orbital encontra a carena genal acima do nível ocular inferior. Carena escrobo-malar inconspícua. Antena afilada no ápice; escapo não ultrapassa a margem do ocelo anterior. Medidas relativas: C:A:L 35:48:81; FV 35; LS 25; EPE 7; ETC 8; EM 10; FO 30; DOA 8; APL 7; OOL 5; POL 15; olho: A:L:LF 45:25:25; antena: anellus $\mathrm{C} 2$; escapo C:L 25:8; pedicelo 7:6; F1 8:9; F2 8:10; F3, F5 e F7 7:11; F4 6:11; F6 6:10; clava 14:10.

Mesossoma. Dorso convexo pilosidade cerca de 2x o diâmetro dos umbílicos, no escutelo mais que $2 \mathrm{x}$ este diâmetro. Umbílicos do pronoto, margem anterior do lobo mediano do mesoscuto e escápula com $0,5 \mathrm{x}$ o DOA; no restante do lobo 
mediano cerca de $0,4 \mathrm{x}$ o DOA e no escutelo atingindo $0,4 \mathrm{x}$ o DOA interstício coriáceo, no pronoto menor que $0,25 \mathrm{x}$ o diâmetro dos umbílicos. Carena pronotal ausente na porção mediano-dorsal por $0,6 \mathrm{x}$ do FV. Umbílicos da margem posterior do pronoto irregulares, suas margens anteriores formam uma carena anterior evidente. Porção superior da lateral do pronoto coriácea, sulco transversal evidente. Escutelo convexo; carena frenal bilobada. Área frenal lisa sem carenas transversais. Mesepisterno com interstício liso. Carena epicnemial bilobada na porção mediano-ventral. Depressão femoral com carenas interrompidas acima da transepimeral. Epímero superior liso. Propódeo areolado-rugoso. Asa anterior com dobra basal indicada por três fileiras de cerdas; dobra cubital indicada por uma fileira de cerdas; célula basal com duas cerdas, linha de cerdas subcubital presente abaixo da dobra cubital. Metafêmur com cinco dentes ventrais, os distais fundidos em lâmina curva (Fig. 25). Metatíbia com espinho curto e agudo (Fig. 25). Medidas relativas: mesossoma C:L 105:75; mesoscuto C 65; escutelo 85:95; asa C:L 190:75; SM 70; M 40; PM 10; ES 5; metacoxa C 50; metafêmur:C:L 82:45.

Metassoma. Pecíolo visível dorsalmente; T1 liso, com pilosidade látero-dorsal reduzida e fina, margem posterior reta; T2-T5 coriáceos, com pilosidade látero-dorsal e margem posterior levemente côncava, T6-T7 coriáceos, com pilosidade látero-dorsal e margem posterior convexa; hipopígio com margem reta. Ápice acuminado. Medidas relativas: gáster C:L 122:58 (+ ovipositor 18); T1 C 60; T7+T8 12:14.

Macho. Semelhante à fêmea exceto por apresentar o ápice do gáster truncado.

Etimologia. Epíteto específico em referência ao clípeo alargado.

Variações. O metafêmur pode não apresentar mancha basal na face externa; a metacoxa pode ser toda preta ou amarela; a porção protraída da bainha ovipositor pode ser um pouco mais longa. $\mathrm{RJ})$.

Distribuição. Panamá, Equador, Brasil (AM, PA, MT, MG,

Hospedeiros. Quatro exemplares de Minas Gerais (Brasil) foram consideratos parasitóides de Trypoxylon fabricator Smith.

Comentários. Esta espécie apresenta semelhança com $C$. acutigaster sp. nov. em relação às mandíbula unidentada, carena frenal bilobada e a porção mediano-ventral da epicnemial bilobada, mas pode ser diferenciada através do metafêmur mais longo que largo e com dentes ventrais distais findidos em lâmina curva (Fig. 25), clípeo alargado e projeção interantenal formada por uma pequena elevação da superfície do escrobo (Fig. 24).

Material examinado. Holótipo fêmea, com etiqueta 'EQUADOR Sucumbios - R. Napo Sacha Lodge, 200masl 12-22.II.1994 legit: Peter Hibbs' (QCAZ). Parátipos. PANAMÁ, Zona do Canal: 2 fêmeas, Ilha
Barro Colorado, X.1928, "nest of Trypoxylon sp" (Phil. Rav) (USMN); 1 fêmea, Ilha Barro Colorado, 14.Vi.1939 (Zetec) (USNM); 1 fêmea, ibidem, V.1939, lot. No. 39-12208 (USNM); COLÔMBIA, Vale del Cauca: 1 fêmea, Palmira, IX.1943 (B. Losada S.) (USNM). EQUADOR, Sucumbios: 1 fêmea, mesmo dados que holótipo, 12-22.III.1994 (QCAZ). BRASIL, Amazonas: 1 macho, Manaus, Campus Universitário, VI.1982, arm. Malaise (J. A. Rafael) (INPA); 1 macho, ibidem, 0108.VI.1982 (INPA); 1 fêmea, Manaus, Campus UFAM, 30.IX.1978 (J.A.Rafael) (INPA); 1 fêmea, Manaus, INTA, VI.1977 (E. Castelón) (INPA); 1 fêmea Manaus, Reserva A. Ducke, 23.IX.1986, arm. Malaise (L. Ulisses) (INPA); Pará: 1 fêmea, Carajás, Serra Norte, Estr. serraria, 18.VI.1983, arm. suspensa (MPEG); 1 fêmea, Belém, Campus do MPEG, 19.V.1989, arm. Suspensa 1,6 m (R. Santos); 1 fêmea, Piratubo, 25.II.1938 (CEELVA) (FIOC); Mato Grosso: 1 fêmea, Utiariti, Rio Papagaio, X.1966 (Lenko \& Pereira) (MZSP); Rio de Janeiro: 2 fêmeas, Rio de Janairo, Jardim Botânico (H. S. Lopes) (MNRJ); 1 fêmea, Rio de Janeiro, Ilha de Jaguanum, 5.X.1982 (D. Hunt) (UCDC); Minas Gerais: 5 fêmeas, [sem dados de procedência] (Peruquetti) (UFV), parasita de $T$. fabricator (UFES).

\section{Ceyxia latilabra sp. nov.}

(Fig. 59)

Diagnose. Cabeça com projeção interantenal indicada por uma saliência pilosa da superfície do escrobo (Fig. 59); labro muito amplo; carena frenal arredondada; carena epicnemial elevada e bilobada na porção mediano-ventral.

Descrição. Fêmea. Comprimento: 5-6,0 mm (Holótipo: 6,0 $\mathrm{mm})$.

Coloração. Negra, exceto: olho; ocelo; mandíbula; face ventral da metacoxa e metade basal do metafêmur castanhos; pernas anteriores e médias; metade apical do metafêmur; metatíbia; tégula e escapo amarelos; asa esfumaçada; pilosidade branca.

Cabeça. Pilosidade tão longa quanto 2x o diâmetro dos umbílicos, mais esparsa no vértice. Umbílicos fronte e porção anterior do vértice com cerca de $0,25 \mathrm{x}$ o DOA, na porção posterior do vértice umbílicos irregulares; interstício coriáceo. Face inferior com pontuação irregular, interstício coriáceo. Vértice com perfil arredondado. Face com perfil convexo. Ocelo anterior não toca a margem do escrobo; este com margem carenada até $0,75 x$ de sua altura, superfície interna lisa. Projeção interantenal indicada por uma saliência pilosa da superfície do escrobo (Fig. 59). Labro muito amplo. Mandíbula unidentada. Carena pós-orbital encontra a carena genal acima do nível ocular inferior. Carena escrobo-malar muito forte na metade superior e mais fraca na metade inferior. Antena afilada no ápice; escapo não atinge a margem do ocelo anterior. Medidas relativas: C:A:L 24:45:86; FV 30; LS 25; EPE 9; ETC 10; EM 10; FO 40; DOA 8; APL 6; OOL 5; POL 13; olho A:L:LFO 42:30:21; antena: escapo C:L 20:8; anellus C 3; pedicelo; 4:5; F1 7:6; F2 7:8; F3-F5 7:9; F6-F7 6:9; clava 12:8.

Mesossoma. Dorso convexo, pilosidade cerca de 1,5x o diâmetro dos umbílicos, no escutelo $2 x$ este diâmetro.Umbílicos do pronoto, margem anterior do lobo mediano do mesoscuto e escápula com 0,3 x o DOA; no restante do lobo mediano cerca de $0,4 \mathrm{x}$ o DOA e no escutelo atingindo $0,5 \mathrm{x}$ o DOA interstício coriáceo. Carena pronotal ausente na porção mediano-dorsal por $0,8 \mathrm{x}$ do FV. Umbílicos da margem posterior do pronoto 
irregulares e delimitam uma carena anterior evidente. Porção superior da lateral do pronoto coriácea, sulco transversal evidente. Escutelo convexo; carena frenal arredondada. Área frenal coriácea com três carenas transversais. Mesepisterno com interstício liso. Carena epicnemial projetada e bilobada na porção mediano-ventral. Depressão femoral com algumas carenas acima da transepimeral. Epímero superior rugoso; Propódeo areolado-rugoso com aréola mediana pentagonal. Asa anterior com dobra basal indicada por uma fileira de cerdas; dobra cubital indicada por uma fileira de cerdas; célula basal com até três cerdas, linha de cerdas subcubital ausente abaixo da dobra cubital Metafêmur com cinco dentes ventrais; o apical o maior. Ápice da metatíbia curto, curvo e agudo. Medidas relativas: mesossoma C:L 95:70; mesoscuto C 65; escutelo 70:90; asas: C:L 190:75; SM 80; M 35; PM 14; ES 5; metacoxa C 45; metafêmur: C: L 75: 40.

Metassoma. Pecíolo visível dorsalmente T1 liso, com pouca pilosidade látero-dorsal e margem posterior reta; T2-5 lisos, com pilosidade látero-dorsal e margem posterior côncava; T6T7 lisos, com pilosidade látero-dorsal, margem posterior convexa; hipopígio emarginado. Ápice acuminado. Medidas relativas: gáster C:L 122:59(+ ovipositor 5); T1 C 48; T7+T8; 6:5.

Etimologia. Epíteto específico em referência ao labro muito amplo.

Variações. A mandíbula pode apresentar dente agudo ou arredondado no ápice, as carenas da depressão femoral podem variar em número; a carena frenal pode variar de arredondada a ligeiramente emarginada.

\section{Distribuição. BRASIL (AM, MA).}

Hospedeiros. Desconhecidos.

Comentários:Esta espécie e as espécies C.laticlipeata $\mathbf{s p .}$ nov., C. acutigaster sp. nov., C. dorsalis comb. nov. apresentam mandíbulas unidentadas, mas esta espécie difere das duas primeiras por apresentar carena frenal arredondada, ao invés de bilobada, e difere de $C$. dorsalis comb.nov. por apresentar mesossoma negro, enquanto essa espécie apresenta mesossoma marrom-avermelhado. Além disso a espécie descrita apresenta como característica, labro muito amplo, o que não ocorre nas outras espécies citadas.

Material examinado. Holótipo fêmea, com a etiqueta 'BRA[SIL]MA[RANHÃO]- Lago Verde Faz[enda] Exp[erimental] Flor[esta] Babaçu III.1982 W. Overal \& A. Anderson, col. (MPEG). Parátipo. 1 fêmea, Amazonas, Campus Universitário, I.VI.1982 (J. A. Rafael) (INPA).

\section{Ceyxia longiarticulata sp. nov.} (Figs. 60-62)

Diagnose. Carena longitudinal acima da depressão foraminal presente; face inferior com uma área elevada e pontuada na região mediana (Fig. 60); F1 2,5x mais longo que largo (Fig. 61); F2-F5 no mínimo 1,3x mais longos que largos.
Descrição. Fêmea. Comprimento: 7 mm (Holótipo)

Coloração. Negra, exceto: olho e ocelos castanhos; tégula, parte ventral do escapo, metade apical da pró-tíbia e mesotíbia, quarto apical e basal da metatíbia, metade apical do pró-fêmur, mesofêmur e mancha apical do metafêmur amarelos; asa esfumaçada; pilosidade branca.

Cabeça. Pilosidade tão longa quanto 2x o diâmetro dos umbílicos, mais esparsa ao redor do ocelo e parte mediana da face inferior. Umbílicos da fronte e porção anterior do vértice com cerca de 0,2x o DOA, umbílicos irregulares na porção posterior do vértice; interstício coriáceo. Face inferior com área mediana elevada e pontuada (Fig. 60), interstício liso. Vértice com perfil arredondado, face convexa. Ocelo anterior toca a margem do escrobo, que é carenada até $0,5 x$ de sua altura; superfície do escrobo lisa. Projeção interantenal como uma carena curta e pilosa. Mandíbula com dente superior vestigial, o inferior longo e agudo. Carena pós-orbital encontra a carena genal no nível da margem inferior do olho. Carena horizontal laminar acima da depressão foraminal presente. Carena escrobo-malar não toca a carena malar. Escapo não ultrapassa a margem inferior do ocelo anterior. Medidas relativas: cabeça C:A:L 35:60:90; FV 42; LS 30; EPE 10; ETC 10; EM 15; FO 35; DOA 10; APL 5; OOL 8; POL 15; olho A:L:LF 47:30:25; escapo C:L 35:8; pedicelo 5:18; anellus C 2; F1 18:7; F2 11:8; F3-F5 10:9; F6 10:10; F7 9:9; clava 15:10.

Mesossoma. Dorso convexo; pilosidade cerca de 2x o diâmetro dos umbílicos, no escutelo $1,5 \mathrm{x}$ este diâmetro. Umbílicos do pronoto, da margem anterior do lobo mediano do mesoscuto e da escápula com 0,3 x o DOA; no restante do lobo mediano e escutelo cerca de $0,4 \mathrm{x}$ o DOA, interstício coriáceo. Carena pronotal ausente na porção mediano-dorsal por 1,0x o FV. Umbílicos da margem posterior do pronoto irregulares, com margens anteriores formando uma carena anterior evidente. Porção superior da lateral do pronoto coriácea, sulco transversal definido e interrompido por uma carena mediana. Escutelo convexo; carena frenal bilobada. Área frenal coriácea com duas carenas transversais inconspícuas. Mesepisterno com interstício liso. Carena epicnemial côncava na porção mediano-ventral. Depressão femoral sem carenas transversais. Epímero superior liso. Propódeo areolado, com aréola mediana pentagonal. Asa anterior com a dobra basal indicada por duas fileiras de cerdas; dobra cubital com uma fileira de cerdas; linha de cerdas subcubital presente abaixo da dobra cubital; célula basal glabra. Metafêmur com seis dentes ventrais (Fig. 62). Metatíbia com espinho apical longo, agudo e levemente curvo. Medidas relativas: mesossoma C:L 110:75; mesosocuto C 70; escutelo 90:100; asa 210:75; SM 83; M 45; PM 10; ES 5; metacoxa C 50; metafêmur: C:L 90:48.

Metassoma. Pecíolo visível dorsalmente; T1-T7 com pouca pilosidade látero-dorsal; T1-T5 lisos e T6-T7 coriáceos; T1 com margem posterior dorsal reta; T2-T5 com margem posterior levemente côncava e T6-T7 com margem posterior convexa; bainha do ovipositor chanfrada; hipopígio com lobo mediano proeminente; ápice acuminado. Medidas relativas: gáster $\mathrm{C}: \mathrm{L}$ 135:55 (+ovipositor 2); T1 C 65; T7+T8 20:5. 
Etimologia. Epíteto específico em referência aos funículos antenais longos.

Distribuição. Brasil (AM).

Hospedeiros. Desconhecidos.

Comentários. C. longiarticulata sp. nov., C. laminata sp. nov. e $C$. longispina sp. nov. compartilham a presença de uma carena acima da depressão foraminal e a presença de uma área elevada epontuada na região mediana da face inferior (Fig. 60 ), mas podem ser diferenciadas por apresentar F1-F3 mais longos que largos em C. longiarticulata (Fig. 61), enquanto que nas outras duas apenas F1 é mais longo que largo. $C$. longiarticulata sp. nov. apresenta a carena epicnemial com margem mediano-ventral côncava enquanto que em $C$. longispina sp. nov. tal estrutura apresenta margem bilobada.

Material examinado. Holótipo fêmea, com as etiquetas 'BRASIL: Amazonas R[eserva] Ducke, 15-X-1981 J. A. Rafael' 'armadilha de Malaise' (INPA).

\section{Ceyxia longiscutellaris sp. nov.}

(Figs. 63-65)

Diagnose. Cabeça com projeção interantenal indicada por uma carena curta e pilosa na porção anterior (Fig. 63); face inferior com área mediana elevada abaixo do escrobo (Fig. 63); carena escrobo-malar incompleta; escutelo longo e bilobado (Fig. 64); metafêmur com três dentes ventrais, o distal maior que o basal (Fig. 65).

\section{Descrição. Fêmea. Comprimento: 8,0 mm (Holótipo)}

Coloração. Negra, exceto: olho e ocelo castanhos; metade basal do escapo, tégula, metade apical do pró-fêmur e mesofêmur, mancha apical e basal da face externa do metafêmur e tíbia amarelos; asa hialina; pilosidade branca.

Cabeça. Pilosidade tão longa quanto $2 \mathrm{x}$ o tamanho dos umbílicos, mais esparsa na área ao redor dos ocelos. Umbílicos da fronte e porção anterior do vértice com cerca de $0,25 \mathrm{x}$ do DOA, na porção posterior do vértice umbílicos irregulares; interstício coriáceo, com cerca de $0,5 x$ o diâmetro dos umbílicos. Face inferior com área mediana elevada abaixo do escrobo (Fig. 63), com pontuação irregular, interstício liso. Vértice com perfil arredondado. Face com perfil convexo. Ocelo anterior toca a margem do escrobo; que é carenada até $0,75 \mathrm{x}$ de sua altura, superfície interna lisa. Projeção interantenal indicada por uma carena curta e pilosa na porção anterior (Fig. 63). Mandíbula bidentada, dente superior vestigial, o inferior longo e agudo. Carena pós-orbital encontra a carena genal no nível ocular inferior. Carena escrobo-malar incompleta. Escapo ultrapassa a margem do ocelo anterior. Medidas relativas: cabeça C:A:L 32:60:90; FV 45; LS 30; EPE 8; ETC 10; EM 13; FO 25; DOA 8; APL 6; OOL 5; POL 15; olho A:L:LF 50:35:25; antena: escapo C:L 35:9; pedicelo 5:5; anellus C2; F1 17:7; F2F3 9:9; F4 8:9; F5 7:9; F6 8:10; F7 7:9 clava 15:9.
Mesossoma. Dorso convexo, pilosidade cerca de 1,5x o diâmetro dos umbílicos, no escutelo 2x o diâmetro dos umbílicos. Umbílicos do pronoto, margem anterior do lobo mediano do mesoscuto e escápula com $0,25 x$ o DOA; no restante do lobo mediano cerca de $0,5 \mathrm{x}$ o DOA e no escutelo atingindo $0,8 \mathrm{x}$ o DOA, interstício coriáceo. Carena pronotal ausente na porção mediano-dorsal pelo mesmo diâmetro do FV. Umbílicos da margem posterior do pronoto irregulares, suas margens anteriores formam uma carena anterior evidente. Porção superior da lateral do pronoto coriácea, sulco transversal bem definido. Escutelo longo e bilobado (Fig. 64); carena frenal fortemente bilobada. Área frenal coriácea com três carenas transversais. Mesepisterno com interstício liso. Carena epicnemial bilobada na porção mediano-ventral. Depressão femoral sem carenas transversais. Epímero superior coriáceo. Propódeo areolado-pontuado. Asa anterior com dobra basal indicada por três fileiras de cerdas; dobra cubital indicada por uma fileira de cerdas; célula basal glabra;linha de cerdas subcubital ausente abaixo da dobra cubital cubital. Metafêmur com três dentes ventrais, o distal maior que o basal (Fig. 65). Ápice da metatíbia longo e agudo. Medidas relativas: mesossoma C:L 130:85; mesosocuto C 80; escutelo 115:105; asa C:L 185:73; SM 72; M 45; PM 12; ES 6; metacoxa C 45; metafêmur: C: L 90: 57.

Metassoma. Pecíolo visível dorsalmente; T1 liso com pouca pilosidade látero-dorsal e margem posterior dorsal reta; T2-T5 coriáceos, com pilosidade látero-dorsal e margem posterior ligeiramente côncava; T6-T7 coriáceos, com pilosidade látero-dorsal e margem convexa. Hipopígio com margem posterior ligeiramente emarginada. Ápice acuminado. Medidas relativas: gáster C:L 160:70 (+ovipositor 11); T1 C 65; $\mathrm{T} 7+\mathrm{T} 8$ 17:15

Etimologia. Epíteto específico em referência ao comprimento do escutelo.

Distribuição. Panamá.

Hospedeiros. Desconhecidos.

Comentários. É semelhante a C. longiarticulata $\mathbf{s p . ~ n o v . , ~}$ C. laminata sp. nov. e C. longispina $\mathbf{s p . ~ n o v . ~ e m ~ r e l a c ̧ a ̃ o ~ a ~}$ carena frenal bilobada (Fig. e espinho da metatíbia longo, mas pode ser diferenciada destas, por não apresentar carena laminar acima da depressão foraminal, pelo escutelo bilobado (Fig. 64) e pelo metafêmur com três dentes ventrais, sendo o distal o maior (Fig. 65).

Material examinado. Holótipo fêmea, com as etiquetas 'BarroColold. CZ. VI-14s89 Zetek-4458' 'LotNo 39-12571' (USMN).

\section{Ceyxia longispina sp. nov.}

(Figs. 26-29)

Diagnose. Antena com F1 mais longo que largo, os outros segmentos mais largos que longos (Fig. 27); área central da 

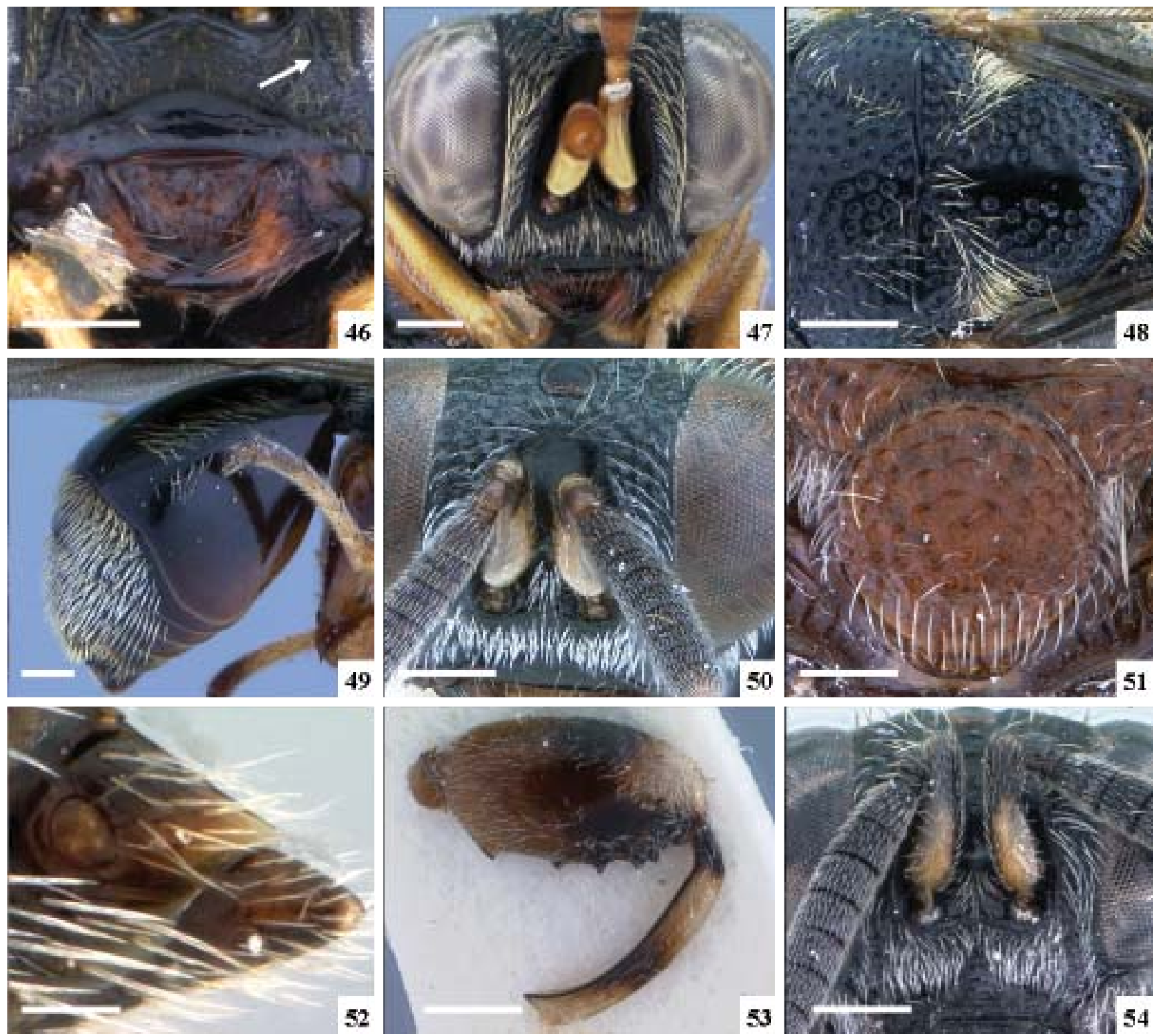

Figs. 46-54. 46-49. Ceyxia bellissima sp. nov., fêmea: 46, face inferior e mandíbula, indicando carena escrobo-malar; 47, cabeça frontal; 48, escutelo dorsal; 49, metassoma lateral. 50-53. Ceyxia fusidentata sp. nov., fêmea: 50, cabeça frontal; 51, escutelo dorsal; 52, metassoma ápice lateral. 53, metafêmur e metatíbia. 54. Ceyxia gibbosa sp. nov., fêmea: 54, cabeça frontal. Escala $400 \mu \mathrm{m}$.

face inferior elevada; carena horizontal acima da depressão foraminal desenvolvida; escutelo com carena frenal alongada, recurvada para cima e bilobada (Fig. 28); espinho apical da metatíbia longo e reto (Fig. 29).

Descrição. Fêmea. Comprimento: 7,5-8,2 mm (Holótipo: 8,2 $\mathrm{mm})$.

Coloração. Negra, exceto: olho e ocelo castanhos; tíbia, tégula $1 / 2$ apical do pró-fêmur e mesofêmur, mancha apical e basal do metafêmur amarelos; asa hialina; pilosidade branca.

Cabeça. Pilosidade tão longa quanto $3 \mathrm{x}$ o diâmetro dos umbílicos, pouco mais esparsa ao redor dos ocelos e face inferior. Umbílicos da fronte e porção anterior do vértice com cerca de 0,2 x o DOA, na porção posterior do vértice pontuação irregular; interstício coriáceo, com cerca de 0,2 x o diâmetro dos umbílicos. Face inferior com pontuação irregular, interstício liso. Vértice com perfil arredondado. Face com perfil convexo. Ocelo anterior toca a margem do escrobo (Fig. 26); que é carenada até $0,75 x$ de sua altura. Superfície interna lisa com parte superior côncava. Projeção interantenal elevada e pilosa. Mandíbula bidentada, dente superior curto (Fig. 26), o inferior longo e agudo. Carena pós-orbital encontra a carena genal no nível ocular inferior. Carena horizontal laminar acima da depressão foraminal. Carena escrobo-malar completa. Escapo não ultrapassa a margem do ocelo anterior. Medidas relativas: C:A:L 40:71:106; FV 50; LS 35; EPE 10; ETC 11; EM 15; FO 35; 
DOA 10; APL 7; OOL 7; POL 18; olho A:L:LF 55:40:29; escapo C:L 42:8; anellus C 3; pedicelo 9:5; F1 13:9; F2-F3 10:11; F4 8:12; F5 9: 11; F6-F7 8:12; clava 15:12.

Mesossoma. Dorso convexo, cerdas cerca de 1,5 x o diâmetro dos umbílicos, no escutelo $2 x$ esse diâmetro. Umbílicos do pronoto, margem anterior do lobo mediano do mesoscuto e escápula com $0,3 \mathrm{x}$ o DOA; no restante do lobo mediano cerca de $0,4 \mathrm{x}$ o DOA e no escutelo atingindo $0,5 \mathrm{x}$ o DOA interstício coriáceo. Carena pronotal ausente na porção mediano-dorsal por $0,8 \mathrm{x}$ do FV. Umbílicos da margem posterior do pronoto irregulares, suas margens anteriores formam uma carena anterior evidente. Porção superior da lateral do pronoto coriácea, sulco transversal definido. Escutelo convexo; carena frenal alongada, recurvada para cima (Fig. 28) e bilobada. Área frenal estriada com três carenas transversais inconspícuas. Mesepisterno com interstício liso. Carena epicnemial bilobada na porção mediano-ventral. Depressão femoral sem carenas acima da transepimeral, abaixo apenas estrias. Epímero superior coriáceo. Propódeo areolado, com aréola mediana pentagonal e finas pontuações. Asa anterior com linha basal indicada por duas fileiras de cerdas; dobra cubital indicada por uma fileira de cerdas; célula basal com duas cerdas, linha de cerdas subcubital ausente abaixo da dobra cubital. Metafêmur com seis dentes ventrais. Metatíbia com espinho apical longo e com ápice reto (Fig. 29). Medidas relativas: mesossoma C:L 139:95; mesoscuto C 85; escutelo 105:120; Asa 240:85; SM 100; M 45; PM 12; ES 7; metacoxa C 50; metafêmur: C:L 100:56.

Metassoma. Pecíolo visível dorsalmente; T1 liso e brilhante, margem posterior dorsal reta; T2-T5 coriáceos, margem posterior levemente côncava; T6-T7 coriáceos, margem posterior convexa; bainha do ovipositor chanfradaarredondada. Ápice acuminado Medidas relativas: gáster C:L 150:75 (+ovipositor 5); T1 C 80; T7+T8 15:10.

\section{Macho. Comprimento: 5,5 mm}

Semelhante à fêmea, exceto por apresentar ápice do gáster não acuminado e segmentos funiculares com pilosodade ventral mais longa e densa.

Etimologia. Epíteto específico em referência ao espinho da metatíbia longo.

Variações. A carena acima da depressão foraminal pode ser menos desenvolvida. Os dentes ventrais do metafêmur podem ser mais desenvolvidos e com cinco a seis dentes ventrais; escultura do propódeo pode ser areolada-rugosa.

\section{Distribuição. Equador, Brasil (AM, MT).}

\section{Hospedeiros. Desconhecidos.}

Comentários. Esta espécie é semelhante a $C$. laminata $\mathbf{s p . ~}$ nov. e $C$. longiarticulata sp. nov. por apresentar carena laminar horizontal acima da depressão foraminal, mas se diferencia através da proporção dos funículos antenais (veja discussão em $C$. laminata sp. nov.), carena frenal recurvada para cima (Fig. 28) e espinho apical da metatíbia reto (Fig. 29) e maior que nas demais.
Material examinado. Holótipo fêmea, com a etiqueta 'ECUADOR: Prov[vincia] Mor[rona] Santiago, Miszel 50km se. Macas 4-7.I.1993 300m M \& J . Wasbauer' (UCDC). Parátipos. BRASIL, Amazonas: 1 fêmea, Manaus, Campus UFAM, 14.X.1978, arm. Malaise (J. A. Rafael) (INPA); 1 fêmea, ibidem, 23.IX.1979 (INPA); 1 fêmea, ibidem, 0108.VI.1982 (INPA); 1 fêmea, Marãe, R. Japurá, Maguari, 26-29.X.1988, arm. Suspensa (J. Dias) (MPEG); Mato Grosso: 1 fêmea, Barra dos Bugres, R. E. Serra das Araras, 24.X.1986, arm. Suspensa 1,6m (MPEG); São Paulo: 1 fêmea, 1 macho, Sete Barras, 99-FBS-BB-10mm, 2.III.2005 (P. Marchi) (DZUP).

\section{Ceyxia nigropetiolata sp. nov.} (Figs. 30-32).

Diagnose. Projeção interantenal indicada por uma carena curta e pilosa na porção anterior (Fig. 30); ocelo anterior distante ao menos $2 \mathrm{x}$ seu diâmetro da margem do escrobo; metassoma com pecíolo visível dorsalmente; hipopígio com margem posterior reta ou levemente emarginada.

Descrição. Macho: Comprimento. 3,7-4,4 mm (Holótipo: 4,4 $\mathrm{mm})$.

Coloração. Negra, exceto: dorso do mesossoma marrom avermelhado; olho, ocelo, antena e mandíbula castanhos; tégula, perna anterior e média; mancha apical do metafêmur e quarto basal e apical da metatíbia amarelos; asa hialina; pilosidade branca.

Cabeça. Pilosidade tão longa quanto 2x o diâmetro dos umbílicos, mais esparsa ao redor dos ocelos e face inferior. Umbílicos da fronte e porção anterior do vértice com cerca de $0,25 x$ do DOA, na porção posterior do vértice umbílicos irregulares; interstício coriáceo. Face inferior com pontuação irregular, interstício liso. Vértice com perfil arredondado. Face com perfil convexo. Ocelo anterior dista da margem superior do escrobo em ao menos seu diâmetro (Fig. 30); este com margem carenada até $0,75 \mathrm{x}$ de sua altura; superfície interna lisa. Projeção interantenal indicada por carena curta e pilosa (Fig. 30). Mandíbula bidentada, dente superior vestigial, o inferior longo e agudo. Carena pós-orbital encontra a carena genal acima do nível ocular inferior. Carena escrobo-malar evidente. Antena afilada no ápice; escapo não ultrapassa a margem do ocelo anterior. Medidas relativas: Cabeça: C:A:L 25:35:62; FV 29; LS 20; EPE 5; ETC 4; EM 10; FO 20; DOA 7; APL 5; OOL 4; POL 10; olho: A:L:LF 35:25:18; antena: escapo C:L 19:5; pedicelo 5:4; F1 6:4; annelus C3; F2 5:7; F3-F7 5:8; clava 10:7.

Mesossoma. Dorso convexo, pilosidade cerca de 2x o diâmetro dos umbílicos. Umbílicos do pronoto, margem anterior do lobo mediano do mesoscuto e escápula com $0,3 \times \mathrm{x}$ o DOA; no restante do lobo mediano cerca de $0,4 \mathrm{x}$ o DOA e no escutelo atingindo $0,5 \mathrm{x}$ o DOA interstício coriáceo, no pronoto menor que $0,5 \mathrm{x}$ o diâmetro dos umbílicos. Carena pronotal ausente na porção mediano-dorsal pela mesma distância do FV. Umbílicos da margem posterior do pronoto irregulares, suas margens anteriores formam uma carena anterior evidente. Porção superior da lateral do pronoto coriácea, sulco transversal evidente. Escutelo convexo; carena frenal levemente emarginada. Área frenal coriácea com três carenas 
transversais. Mesepisterno com interstício liso. Carena epicnemial emarginada na porção mediano-ventral. Depressão femoral com carenas transversais interrompidas acima da transepimeral. Epímero superior rugoso. Propódeo areoladorugoso com aréola mediana pentagonal (Fig. 31). Asa anterior com dobra basal indicada por duas fileiras de cerdas; dobra cubital indicada por uma fileira de cerdas; linha de cerdas subcubital ausente abaixo da dobra cubital. Metafêmur com sete a oito dentes ventrais diminutos. Ápice da metatíbia com espinho curto, rômbico e levemente curvo. Medidas relativas: mesossoma C:L 75:55; mesoscuto C 45; escutelo 50:65; asa C:L 150:60; SM 65; M 27; PM 10; ES 5; metacoxa C 40; metafêmur: C:L 55:25.

Metassoma. Pecíolo visível dorsalmente (Fig. 32); T1 liso com pouca pilosidade látero-dorsal e margem posterior reta; T2-T5 lisos com pilosidade látero-dorsal e margem posterior levemente côncava; T6-T7 lisos com pilosidade látero-dorsal e com margem posterior convexa. Ápice truncado. Medidas relativas: gáster C:L 75:45; T1 30:45; T7+T8 7:10.

Etimologia. Epíteto específico em referência ao pecíolo negro visível dorsalmente.

\section{Distribuição. Amazonas (Manaus).}

Hospedeiros. Desconhecidos.

Comentários. Semelhante a $C$. dorsalis comb. nov., $C$. gibbosa sp. nov. e $C$. fusidentata sp. nov. por apresentar mesossoma marrom avermelhado, espinho da metatíbia curto, ocelo anterior fora do escrobo e pecíolo visível dorsamente (Fig. 32). Difere de C. dorsalis comb. nov. através da projeção interantenal carenada (Fig. 30), porção mediano-ventral da carena epicnemial emarginada e carena frenal não refletida para cima. Difere de $C$. gibbosa sp. nov. e $C$. fusidentata $\mathbf{s p . ~ n o v . ~ p o r ~}$ apresentar carena frenal suavemente emarginada; projeção interantenal indicada por uma carena curta e pilosa e metafêmur com sete a oito dentes ventrais diminutos.

Material examinado. Holótipo macho, com a etiqueta 'BRA[SIL]AM[AZONAS]- Manaus ZF3-km23-Res. 1112 26.II.1986, arm. Malaise, Bert Clain, col.' (INPA). Parátipos. 6 machos, ibidem (INPA); 1 macho, ibidem, 22.X.1986 (INPA).

\section{Ceyxia paraensis sp. nov.} (Fig. 66)

Diagnose. Funículos antenais mais largos que longos; escutelo com parte central sem umbílicos e interstício liso; carena frenal curta e suavemente emarginada; propódeo com aréola mediana pentagonal dividida longitudinalmente (Fig. 66); metatíbia com espinho apical longo e agudo; carena epicnemial curta e reta na porção mediano-ventral.

Descrição. Fêmea. Comprimento: 7,2 mm (Holótipo)

Coloração. Negra, exceto: olho e ocelo castanhos; escapo, tégula, metacoxa, pró-tíbia e; mesotíbia, metade apical e basal da metatíbia, mancha apical e basal do metafêmur amarelos; asa hialina; pilosidade branca.

Cabeça. Pilosidade mais esparsa ao redor do ocelo, fina e rala em todo mesossoma. Umbílicos fronte e porção anterior do vértice com cerca de $0,25 x$ do DOA, na porção posterior do vértice umbílicos irregulares; interstício coriáceo. Face inferior com pontuação rasa e irregular, interstício liso. Vértice com perfil arredondado. Face com perfil convexo. Ocelo anterior toca a margem do escrobo; este com margem carenada até $0,75 x$ de sua altura, superfície interna lisa. Projeção interantenal forma uma carena curta e pilosa. Mandíbula bidentada, dente superior vestigial. Carena pós-orbital encontra a carena genal acima do nível ocular inferior. Carena escrobo-malar conspícua. Antena alargada no ápice; escapo ultrapassa a margem do ocelo anterior. Medidas relativas: cabeça C:A:L 40:60:95; FV 40; LS 25; EPE 8; ETC 10; EM 11; FO 40; DOA 10; APL 5; OOL 5; POL 10; olho: A:L:LF 50:40:25; anellus C 2; escapo C:L 35:7; pedicelo 5:4; F1 7:9; F2 6:10; F3 8:12; F4-F5 8:11; F6 8:12; F7 7:12; clava $15: 13$

Mesossoma. Dorso convexo, pilosidade cerca de 2x o diâmetro dos umbílicos, no escutelo 1,5x. Umbílicos do pronoto, lobo mediano do mesoscuto, escápula e escutelo com 0,4x o DOA. Escutelo com parte central sem umbílicos e interstício liso (Fig. 66). Carena pronotal ausente na porção mediano-dorsal por $0,8 \mathrm{x}$ do FV. Umbílicos da margem posterior do pronoto irregulares, suas margens anteriores formam uma carena anterior evidente. Porção superior da lateral do pronoto coriácea, sulco transversal definido. Escutelo plano; carena frenal suavemente emarginada (Fig. 66). Área frenal rugosa com uma série de carenas transversais. Mesepisterno com interstício liso. Carena epicnemial reta na porção medianoventral. Depressão femoral com carenas inconspícuas e incompletas acima da transepimeral; epímero superior liso. Propódeo com aréola mediana dividida por uma carena horizontal (Fig. 66). Asa anterior comdobra basal indicada por três fileiras de cerdas; dobra cubital indicada por uma fileira de cerdas; célula basal com uma a duas cerdas; linha de cerdas subcubital ausente abaixo da dobra cubital. Metafêmur com dez dentes ventrais. Ápice da metatíbia longo e agudo. Medidas relativas: mesossoma C:L 120:85; mesoscuto C 70; escutelo 85:100; asa C:L 200:75; SM 80; M 40; PM 10; ES 5; matacoxa C 60; metafêmur: C:L 80:50.

Metassoma. Pecíolo visível dorsalmente; T1 longo e deprimido dorsalmente, escultura lisa, margem posterior reta; T2-T5 lisos com pontuação pilosa látero-dorsal; T6-T7 coriáceos; com pontuação umbilicada, margem posterior convexa. Ápice acuminado. Medidas relativas: gáster $\mathrm{C}: \mathrm{L}$ 130:60 (+ ovipositor); T1 C 70; T7+T8 8:8.

Etimologia. Epíteto específico em referência ao estado onde se encontra a localidade tipo.

Distribuição. Brasil (PA).

Hospedeiros. Desconhecidos. 
Comentários. Esta espécie é semelhante à $C$. bellissima sp. nov. por apresentar escutelo plano, liso, sem umbílicos na região central (Fig. 66) e metassoma deprimido dorsalmente, mas apenas esta espécie apresenta carena frenal emarginada, aréola mediana do propódeo dividida por uma carena horizontal (fig. 66) e carena epicnemial reta na porção mediano-ventral.

Material examinado. Holótipo fêmea, com a etiqueta 'BRASILPA- Santarém, Nova Curuá-Una Arm. Moericke 11.iv.1998 A.R. Lisboa, col.' (DCBU).

\section{Ceyxia parvidentata sp. nov.}

(Figs. 33-34)

Diagnose. Mandíbula com dente superior vestigial e afastado do ápice; escutelo curto; carena frenal curta, translúcida e suavemente emarginada; metatíbia com espinho apical curto e agudo (Fig. 33).

Descrição. Fêmea. Comprimento: 6,2-6,7 mm (Holótipo: 6,4 $\mathrm{mm})$.

Coloração. Negra, exceto: olho e ocelo castanhos; tégula, escapo, tíbia, metade apical do mesofêmur e mancha apical e basal do metafêmur amarelos; asa hialina; pilosidade branca.

Cabeça. Pilosidade tão longa quanto $3 \mathrm{x}$ o diâmetro dos umbílicos, mais esparsa ao redor do ocelo e face inferior. Umbílicos da fronte e porção anterior do vértice com cerca de $0,25 \mathrm{x}$ do DOA, na porção posterior do vértice umbílicos irregulares; interstício coriáceo. Face inferior com pontuação irregular, interstício liso. Vértice com perfil arredondado. Face com perfil convexo. Ocelo anterior não toca a margem do escrobo; este com margem carenada até $0,75 \mathrm{x}$ de sua altura, superfície interna lisa. Projeção interantenal forma uma carena curta e pilosa. Mandíbula bidentada, dente superior vestigial, o inferior longo e agudo. Carena pós-orbital encontra a carena genal pouco acima do nível ocular inferior. Carena escrobomalar completa. Escapo ultrapassa a margem do ocelo anterior. Medidas relativas: cabeça C:A:L 30:50:80; FV 37; LS 25; EPE 6; ETC 8; EM 10; FO 30; DOA 8; APL 6; OOL 5; POL 15; olho A:L:LF 45:25:24; escapo C:L 26:8; anellus C 2; pedicelo 5:4, F1 8:9; F2 10:7; F3-F7 7:10; clava 16:10.

Mesossoma. Dorso convexo, cerdas com cerca de 3x o diâmetro dos umbílicos, no escutelo cerca de $1 \mathrm{x}$ esse diâmetro. Umbílicos do pronoto, margem anterior do lobo mediano do mesoscuto e escápula com $0,25 \mathrm{x}$ o DOA; no restante do lobo mediano cerca de $0,35 \mathrm{x}$ o DOA e no escutelo atingindo $0,5 \mathrm{x}$ o DOA, interstício coriáceo, carena pronotal ausente na porção mediano-dorsal pela mesma distância do FV. Umbílicos da margem posterior do pronoto irregulares, suas margens anteriores formam uma carena anterior evidente. Porção superior da lateral do pronoto coriácea, sulco transversal evidente e interrompido por uma carena mediana. Escutelo convexo; carena frenal curta, suavemente emarginada e translúcida. Área frenal rugosa com três carenas transversais incospícuas. Mesepisterno com interstício liso. Carena epicnemial bilobada na porção mediano-ventral. Depressão femoral com carenas transversais evidentes. Epímero superior liso. Propódeo areolado-rugoso com aréola mediana pentagonal. Asa anterior com dobra basal indicada por duas fileiras de cerdas; dobra cubital indicada por uma fileira de cerdas; célula basal glabra, linha de cerdas subcubital presente abaixo da dobra cubital. Metafêmur com cinco dentes ventrais. Metatíbia com espinho curto e agudo (Fig. 33). Medidas relativas: mesossoma C:L 100:80; mesoscuto C 70; escutelo 75:95; asa C:L 175:70; SM 70; M 35; PM 10; ES 5; metacoxa C 50; metafêmur: C:L 40:75.

Metassoma. Pecíolo visível dorsalmente; T1 liso com pilosidade látero-dorsal, e margem posterior reta; T2-T5 lisos com pilosidade látero-dorsal e margem posterior levemente côncava, T6-T7 coriáceos, com pilosidade látero-dorsal e margem posterior convexa; hipopígio com lobo mediano proeminente; bainha do ovipositor chanfrada. Ápice acuminado (Fig. 34); Medidas relativas: gáster C: L 125:55 (+ovipositor 10); T1 C 60; T7+T8 20:10.

Etimologia. Epíteto específico em referência ao dente superior da mandíbula muito pequeno.

Variações. Metafêmur com cinco a sete dentres ventrais e a carena frenal pode ser mais curta.

Distribuição. Panamá, Venezuela, Equador e Brasil (PA, PB, SP).

Hospedeiros. Desconhecidos.

Comentários. Assemelha-se a C. decreta comb. nov. em relação ao comprimento do gáster e coloração do corpo, mas são diferenciadas através do dente superior da mandíbula, que em $C$. decreta comb. nov. é desenvolvido e em $C$. parvidentata sp. nov. é vestigial, o espinho apical da metatíbia, que nas duas espécies é curto, mas em C. parvidentata $\mathbf{s p .}$ nov. possui o ápice mais estreito (Fig. 33). Além disso, $C$. decreta comb. nov. apresenta carena frenal com a margem posterior reta e $C$. parvidentata $\mathbf{s p . ~ n o v . ~ a p r e s e n t a ~ c a r e n a ~ f r e n a l ~}$ suavemente emarginada.

Material examinado. Holótipo fêmea, com as etiquetas 'Brasil Paraíba João Pessoa, Reserva do Buraquinho-IBDF 29.I-1.II.1989' 'Armadilha Suspensa 1.6 m' 'F. F. Ramos' (MPEG). Parátipos. PANAMÁ, Zona do canal: 1 fêmea, Ft Kobbe, IX.1952 (F. S. Blanton) (USNM). VENEZUELA, Zulia: 1 fêmea, El Tucuco, Perija, 24.VI.1979 (R. W. Brooks, A Grigarick, J. M. Claughlin. R. O. Shuster) (UCDC), BRASIL, Amazonas: 1 fêmea, Manaus, Reserva Ducke, 7.XII.1988, arm. Suspensa 20 m (J.A.Rafael) (INPA); Pará: 1 fêmea, Tucuri, Rio Tocantins, Canoal, 28.III.1984, armadilha Malaise (MPEG); São Paulo: 1 fêmea, Nova Europa, Faz. Itaquerê, 24-31.VIII.1965 (Lenko \& Pereira) (MZSP). Outro exemplar estudado: EQUADOR, Napo: 1 fêmea (udissecada para microscopia de varredura), Jatun Sacha Biol St. $20 \mathrm{~km}$ of Puerto Napo, 450 m, 7.I.1989 (K. R Hobson \& E. A. Bergey) (EMEC);

\section{Ceyxia perparva sp. nov.}

(Figs. 35-36)

Diagnose. Projeção interantenal formada por uma elevação da superfície do escrobo; carena frenal suavemente emarginada 

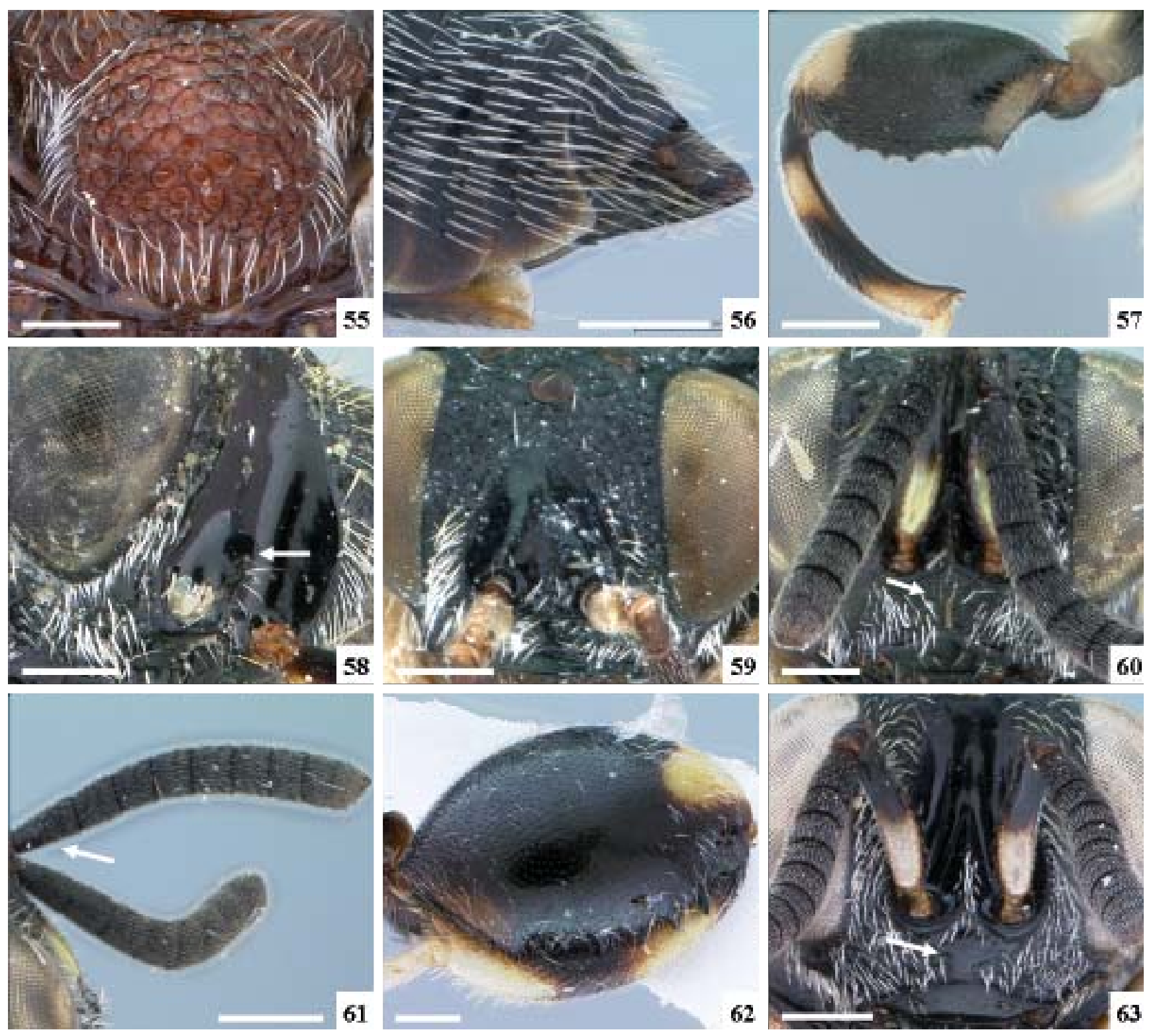

Figs. 55-63. 55-57. Ceyxia gibbosa sp. nov., fêmea: 55, escutelo dorsal; 56, metassoma ápice lateral. 57, metafêmur e metatíbia. 58. Ceyxia laminata sp. nov., fêmea, cabeça diagonal, indicando a projeção interantenal. 59. Ceyxia latilabra sp. nov., fêmea, cabeça frontal. 60-62. Ceyxia longiarticulata sp. nov., fêmea: 60, cabeça frontal, indicando área elevada na face inferior; 61, antena, indicando F1; 62, metafêmur e metatíbia. 63. Ceyxia longiscutellaris sp. nov., fêmea, cabeça frontal, indicando área elevada na face inferior. Escala $400 \mu \mathrm{m}$.

(Fig. 35); espinho da metatíbia curto, agudo e curvo (Fig. 36); T1 com pontuado próximo a margem dorso-posterior.

Descrição. Fêmea. Comprimento: 4,2-5,0 mm (Holótipo: 4,7 $\mathrm{mm})$.

Coloração. Negra, exceto: olho e ocelo castanhos; tíbias, tégula, metade apical do pró-fêmur e mesofêmur e mancha apical do metafêmur amarelos; asa hialina; pilosidade branca.

Cabeça. Pilosidade de 2x o diâmetro dos umbílicos, mais esparsa ao redor dos ocelos. Umbilicos da fronte e porção anterior do vértice de $0,3 \mathrm{x}$ o DOA, na porção posterior do vértice umbílicos irregulares; interstício coriáceo. Face inferior com pontuação reduzida, interstício liso. Vértice com perfil arredondado. Face com perfil convexo. Ocelo anterior distado do topo do escrobo em ao menos seu diâmetro; escrobo com margem carenada até $0,75 \mathrm{x}$ de sua altura, superfície interna lisa na parte inferior e rugosa na parte superior. Projeção interantenal formada por uma elevação da superfície do escrobo. Mandíbula bidentada, dente superior vestigial, o inferior longo e agudo. Carena pós-orbital encontra a carena genal pouco acima do nível ocular inferior. Carena escrobomalar conspícua e completa. Antena afilada no ápice; escapo não ultrapassa a margem do ocelo anterior. Medidas relativas: C:A:L 40:65:104; FV 48; LS 35; EPE 10; ETC 9; EM 15; FO 40. DOA 10; APL 10; OOL 5; POL 20; olho A:L:LF 45:35:28; antena: escapo C:L 34:9; pedicelo 5:4; anellus C 2 F1 11:10; F2-F3 9:11; 
F4 8:11; F5-F6 9:11; F7 9:12; clava 20:12.

Mesossoma. Dorso convexo, pilosidade cerca de 1,5x o diâmetro dos umbílicos. Pontuação umbilicada do pronoto, margem anterior do lobo mediano do mesoscuto e escápula com 0,3x o DOA; no restante do lobo mediano e escutelo cerca de 0,6x o DOA; interstício coriáceo. Carena pronotal ausente na porção mediano-dorsal por $0,7 \mathrm{x}$ do FV. Umbílicos da margem posterior do pronoto irregulares, suas margens anteriores formam uma carena anterior evidente. Porção superior da lateral do pronoto coriácea, sulco transversal conspícuo. Escutelo convexo; carena frenal suavemente emarginada (Fig. 35). Área frenal coriácea com três carenas transversais incospícuas. Mesepisterno com interstício liso. Carena epicnemial bilobada na porção mediano-ventral. Depressão femoral com carenas inconspícuas acima da transepimeral. Epímero superior coriáceo. Propódeo areolado-rugoso com aréola mediana pentagonal. Asa anterior com dobra basal indicada por duas fileiras de cerdas; dobra cubital indicada por uma fileira de cerdas, linha de cerdas subcubital presente abaixo da dobra cubital. Metafêmur com cinco dentes ventrais. Ápice da metatíbia curto agudo e com ápice curvo (Fig. 36). Medidas relativas: mesossoma C:L 120:85; mesosocuto C 50; escutelo 55:70; asa 220:85; SM 90; M 40; PM 10; ES 5; metacoxa C 60; metafêmur: C: L 90: 50.

Metassoma. Pecíolo visível dorsalmente. T1 liso, com poucas cerdas e pontuações nas laterais, margem posterior reta; T2-T4 lisos, com pilosidade látero-dorsal e margem posterior levemente côncava; T6-T7 com pontuação umbilicada, interstício coriáceo e margem posterior convexa; bainha do ovipositor chanfrada; hipopígio convexo. Ápice acuminado. Medidas relativas: gáster C:L 140:50 (+ ovipositor 10); T1 C 75; T7+T8 15:5.

Etimologia. Epíteto específico em referência à projeção interantenal muito reduzida.

Variações. A carena frenal pode ser arredondada; a metacoxa pode ser marrom ou preta; o metafêmur pode apresentar dentes ventrais menores e coloração marrom. No exemplar do Pará a coloração do gáster e escutelo são marrons.

Distribuição. Costa Rica, Brasil (AM, PA, MT, DF, MG, ES, SP, SC).

Hospedeiros. Um exemplar de Trinidad e Tobago foi criado de Trypoxylon midli bodkini Richards.

Comentários. Esta espécie é semelhante à $C$. concitator comb. nov. em relação ao dente superior da mandíbula vestigial, coloração do corpo e posição do ocelo, distando do topo do escrobo por ao menos seu diâmetro, mas pode ser diferenciada desta espécie por apresentar projeção interantenal não carenada, carena frenal suavemente emarginada (Fig. 35) e espinho apical da metatíbia curto com ápice curvo (Fig. 36).

Material examinado. Holótipo fêmea, com a etiqueta 'BRA[SIL] AM[AZONAS] - Manaus ZF3-km23-Res. 1112 17.XII.1985 Arm. Malaise Bert Klein, col' (INPA). Parátipos. MÉXICO, Jalisco: 1fêmea,
Yelapa, 25.IV.1977 (D.G. Denning) (UCDC). COSTA RICA, Heredia: 1 fêmea, Finca La Selva, 'in forest cut', 7.X.1981, 'flight trap' (Ch. Griswold) (AMNH); 1 macho, Puerto Viejo, 15.VIII.1965 (R.J.Hamton) (LACM) Alajuela: 1 fêmea, Alajuela, 8-28.II.1970, arm. Malaise (O. Peck) (CNCI). TRINIDAD E TOBAGO, Trinidad: 1 fêmea, Arima Valley, Spring Hill Estate, 09.III.1964 (C.E.Ross) (CAS); 1 fêmea, Sain Augustin, 6.I.1942, 'from trypoxylon bodkini Rich. Nest' (E. McC. Calan) (USNM). VENEZUELA, Aragua: 1 fêmea, $2 \mathrm{~km} \mathrm{~N}$ Ocumare de la Costa, 31-III.02.IV.1981 (A.S. Menke \& E. Hllemberg) (USNM); 1 fêmea, ibidem, 21-22.VI.1976 (A.S.Menke \& D. Vincent) (USNM). EQUADOR, Napo: 1 fêmea, Coca, III.1986 (G. Onore) (QCAZ); 1 fêmea, ibidem, VI. 1986 (QCAZ). BOLIVIA, El Beni: 1 fêmea, NE of San Borja, Beni Stn., Palm Camp., Savanah, 28.VII.1988, arm. Malaise (R.W. Books) (USNM). BRASIL, Roraima: 1 fêmea, Ilha de Maracá, Rio Uraricoera, 21-30.XI.1987, arm Malaise (J. A. Rafael) (INPA); Amazonas: 1 fêmea, Manaus, Campus UFAM, 26.VIII.1978, arm Malaise (J. A. Rafael) (INPA); 2 fêmeas, ibidem, 23.XII.1978 (INPA); 1 fêmea, ibidem, 24.II.1979 (INPA); 1 fêmea, ibidem, 15.V.1979 (INPA); 1 fêmea, ibidem, 11.VIII.1979 (INPA); 1 fêmea, Manaus, Campus Universitário, 1.VI.1982 (INPA); 1 fêmea, ZF3 Km 23 Res. 1210, 09.I.1986, arm. Malaise (Bert Clain) (INPA); 1 fêmea, ibidem, 01.X.1986 (INPA); 1 fêmea, ibidem, Res. 1112, 04.VI.1985 (INPA); 1 fêmea, ibidem, 13.V.1986 (INPA); 1 fêmea, Manaus, Reserva Campina, 27.III.1990, arm Malaise (J. Vidal \& J. Vidal) (INPA); 1 fêmea, Manaus, Reserva Ducke, 03.XI.1988, arm. Suspensa 10m (J.A. Rafael) (INPA); 1 fêmea, ibidem, 10.VII.1990 (Vidal \& Vidal) (INPA); 1 fêmea, Humaitá, 15-17.IX.1990, arm suspensa (R. Constantino) (MPEG); Pará: 3 fêmeas, Rio Xingu, 60 km S. Altamira, 2-16.X.1986 (P. Spangler \& O. Flint) (USNM); 1 fêmea, Faz. Taperinha, 1821.XI.1969 (J. M \& B. A. Campbell) (CNCI); Mato Grosso: 1 macho, Rondonópolis, área indig. Tadarimana Mata, 31.X.1991, varredura de vegetação (M. T. Tavares) (UFES); Distrito Federal: 1 fêmea, Res. Ecol. IBGE Km 0 Br 251, 08-22.VII.1982 (IBGE); Minas Gerais: 1 fêmea, Belo Horizonte, Estação Ecológica, 28.XI.1996, arm Malaise (J. C. R. Fontenelle) (UFMG); Espirito Santo: 1 macho, Santa Teresa, 09.III.1989, parasita de Sphecidae (A. P. Aguiar) (MBML); São Paulo: 1 fêmea, Faz. Chanchim, cerrado, 03.X.1986, varredura (A. S. Soares)(DCBU); 1 fêmea, ibidem, mata, 28.II.1990, arm susupensa (N.W. Perioto); 1 macho, Barueri, 5.VI.1966 (K. Lenko) (MZSP); 4 fêmeas, 1 macho, Rio Claro, UNESP, ex: ninho de Trypoxylini (N. N. O. Pinto) (UFES); Santa Catarina: 1 fêmea, Nova Teutonia, II.1964 (Fritz Plaumann) (MCZH). Sem localidade definida: 6 fêmeas, 1 machos, UFV, $n^{\circ}$ 11, 6.IV.1992 (L.F.G.) (UFES); 4 machos, ibidem, $n^{\circ} 8$ (UFES); 1 fêmea, 22.XI.1991 (L.F.G); 2 machos, ninho 2, 10.I.1992 (L.F.G.) (UFES).

\section{Ceyxia pseudovillosa sp. nov.}

(Figs. 37-39).

Diagnose. Cabeça com carena longitudinal curta acima do forâmen occipital (Fig. 38); escapo não ultarpassa a margem inferior do ocelo anterior; metafêmur com dente ventral basal tão grande quanto o dista (Fig. 39).

Descrição. Fêmea. Comprimento: 7,1-9,5 mm (Holótipo: 7,1 $\mathrm{mm})$.

Coloração. Negra, exceto: olho e ocelo castanhos; escapo, metade apical e basal da pró-tíbia, mesotíbia e metatíbia, quarto apical do pró-fêmur e mesofêmur; tarso e tégula amarelos; asa enegrecida; pilosidade geral branca, dourada no vértice, lateral do pronoto, dorso do mesossoma e gáster.

Cabeça. Pilosidade tão longa quanto $2 \mathrm{x}$ o tamanho dos umbílicos, mais esparsa ao redor dos ocelos. Umbílicos da fronte e porção anterior do vértice com cerca de $0,25 \mathrm{x}$ o DOA, na porção posterior do vértice irregulares; interstício coriáceo. 
Face inferior com pontuação irregular; interstício liso e perfil convexo. Vértice com perfil arredondado. Face com perfil convexo. Ocelo anterior toca a margem do escrobo; que é carenada até $0,75 \mathrm{x}$ de sua altura; superfície interna com área central lisa, laterais e parte superior estriada. Projeção interantenal forma uma carena curta e pilosa (Fig. 37). Mandíbula unidentada. Carena pós-orbital encontra a carena genal pouco acima do nível ocular inferior. Carena escrobomalar completa. Antena afilada com clava afilada no ápice; escapo ultrapassa a margem do ocelo anterior. Occipício com carena longitudinal curta acima do forâmen (Fig. 38). Medidas relativas: C:A:L 30:55:90; FV 45; LS 35; EPE 7; ETC 10; EM 15; FO 45; DOA 10; APL 5; OOL 5; POL 15; olho A:L:LF 48:30:25; escapo C:L 25:10; anellus C 2; pedicelo 5:5; F1 10:8; F2-F7 10:10; clava 15:9.

Mesossoma. Dorso convexo; pilosidade cerca de 1,5 x o diâmetro dos umbílicos, no escutelo com a mesma medida. Pontuação umbilicada do pronoto, margem anterior do lobo mediano do mesoscuto e escápula com $0,25 x$ o DOA; no restante do lobo mediano e escutelo cerca de $0,5 \mathrm{x}$ o DOA, interstício coriáceo. Carena pronotal ausente na porção mediano-dorsal por $0,7 \mathrm{x}$ do FV. Umbílicos da margem posterior do pronoto irregulares, suas margens anteriores formam uma carena anterior evidente. Porção superior da lateral do pronoto coriácea, sulco transversal bem definido e interrompido por uma carena mediana. Escutelo convexo; carena frenal bilobada. Área frenal coriácea com três carenas transversais. Mesepisterno com interstício liso. Carena epicnemial bilobada na porção mediano-ventral. Depressão femoral com várias carenas transversais acima da transepimeral. Epímero superior liso. Propódeo areolado com aréola mediana pentagonal. Asa anterior com dobra basal indicada por três fileiras de cerdas; dobra cubital indicada por uma fileiras de cerdas; célula basal glabra, linha de cerdas subcubital presente abaixo da dobra cubital. Metafêmur com seis a sete dentes ventrais, o apical tão grande quanto o basal (Fig. 39). Metatíbia com espinho apical rômbico e curto. Medidas relativas: mesossoma $\mathrm{C}: \mathrm{L}$ 115:85; mesoscuto C 100; escutelo 120:130; asa 240:85; SM 100; M 48; PM 20; ES 5; metacoxa C 65; metafêmur: C:L 80:50.

Metassoma. Pecíolo não visível dorsalmente; T1 liso com pouca pilosidade látero-dorsal, margem posterior reta; T2-T5 lisos com pilosidade látero-dorsal e margem posterior levemente côncava; T6-T7 completamente pontuados, interstício liso, com pilosidade látero-dorsal e margem posterior convexa; bainha do ovipositor com ápice arredondado; hipopígio convexo. Ápice acuminado. Medidas relativas: gáster C:L 140:75 (+ovipositor 5); T1 C 60; T7+T8 10:10.

Etimologia. Epíteto específico em referência a sua semelhança com a espécie Ceyxia villosa comb. nov..

Variações. Pilosidade pode ser mais densa; sulco transversal do pronoto não interrompido por carena; dentes ventrais do metafêmur podem variar em tamanho, mas os dentes distais e basais são sempre de tamanho semelhante e maior que os demais.
Distribuição. Brasil (AM, PA, BA).

Hospedeiros. Desconhecidos.

Comentários. Esta espécie difere das outras espécies do grupo por apresentar carena longitudinal acima do occipício (Fig. 38). É semelhante a $C$. villosa comb. nov., mas ao contrário dessa espécie, em Ceyxia pseudovillosa sp. nov. o escapo ultrapassa a margem do ocelo anterior, a pilosidade do corpo é menos densa, pilosidade da cabeça e pernas é branca, e o dente basal e apical do metafêmur são do mesmo tamanho (Fig. 39).

Material examinado. Holótipo fêmea, com a etiqueta 'BRASIL: Amazonas, Manaus, Campus Univ[versitário] VI-1982 JA Rafael mal[laise] $\operatorname{tr}[a p]$ (INPA). Parátipos. BRAZIL. Amazonas: 1 fêmea, Manaus, ZF 3 KM 23 Res. 1112, 13.V.1986, arm. Malaise (Bert Klein) (INPA); Pará: 1 fêmea, Carajás, S. Norte, 16-19.X.1984, arm. Malaise (MPEG); Bahia: 1 fêmea, Ilhéus, 1447'45"S 39¹0’14"W, IX.2002 (M. A. L Bittencourt) (UFES); Sem indicação de estado ou município: 1 fêmea, 07.VII.1967, 'Wasp nest in bird' (USNM).

\section{Ceyxia tibiodilatata sp. nov.} (Figs. 67-69)

Diagnose. Cabeça globosa; corpo pouco piloso; escutelo plano, região central com umbílicos esparsos e ausentes no centro, interstício coriáceo (Fig. 68); propódeo com carena mediana completa; metafêmur com parte basal estreita que a distal (Fig. 69); metatíbia alargada e comprimida no ápice (Fig. 69).

Descrição: Fêmea. Comprimento: 2,6 mm (Holótipo)

Coloração. Negra, exceto: olho e ocelo castanhos; tégula, parte basal e apical da metatíbia amarelas; antena e escapo marrom claros; asa hialina; pilosidade branca.

Cabeça. Pilosidade tão longa quanto $2 \mathrm{x}$ o tamanho dos umbílicos, mais esparsa ao redor dos ocelos e parte posterior do vértice. Umbílicos da fronte e porção anterior do vértice com cerca de $0,25 x$ o DOA, na porção posterior do vértice umbílicos irregulares; interstício coriáceo, com cerca de 0,3 x o diâmetro dos umbílicos. Face inferior com pontuação irregular, interstício coriáceo. Vértice com perfil arredondado. Face com perfil convexo. Ocelo anterior não toca a margem do escrobo (Fig. 67); que écarenada até 0,75x de sua altura, superfície interna lisa. Projeção interantenal indicada por uma carena curta e pilosa na porção anterior (Fig. 67). Mandíbula bidentada; dente superior vestigial, o inferior longo e agudo. Carena pósorbital encontra a carena genal no nível ocular inferior. Carena escrobo-malar evidente. Escapo não ultrapassa a margem do ocelo anterior. Medidas relativas: C:A:L 20:25:30; FV 17; LS 12; EPE 5; ETC 4; FO 10; DOA 4; APL 3; OOL 3; POL 5: olho: A:L:LF 23:15:11; antena: escapo C:L 14:4; pedicelo 3:4; anellus C 2; F1 3:3, F2 3:4, F3-F6 4:4, F7 4:5, clava 9:4.

Mesossoma. Dorso plano, pilosidade cerca de 1,5x o diâmetro dos umbílicos. Umbílicos do pronoto, margem anterior do lobo mediano do mesoscuto e escápula com 0,3 x o 
DOA; no restante do lobo mediano cerca de $0,4 \mathrm{x}$ o DOA e no escutelo atingindo 0,5x o DOA, interstício coriáceo (Fig. 68). Carena pronotal ausente na porção mediano-dorsal por $0,7 \mathrm{x}$ do FV. Umbílicos da margem posterior do pronoto irregulares, suas margens anteriores formam uma carena anterior evidente. Porção superior da lateral do pronoto coriácea, sulco transversal evidente. Escutelo plano; carena frenal suavemente emarginada (Fig. 68) Área frenal coriácea com três carenas transversais. Mesepisterno com interstício liso. Carena epicnemial emarginada na porção mediano-ventral. Depressão femoral com várias carenas transversais acima da transepimeral. Epímero superior coriáceo. Propódeo areolado-rugoso com carena mediana completa, sem formar aréola pentagonal. Metafêmur com parte basal mais estrita que a distal, com seis dentes ventrais (Fig. 69). Metatíbia com ápice alargado, comprimido lateralmente e com espinho curto (Fig. 69) Medidas relativas: mesossoma C:L 40:30; mesoscuto C 25; escutelo 30:35; asa C:L 80: 25; SM 30; M 10; PM 3; ES 4; metacoxa C 20; metafêmur: C:L 33:20.

Metassoma. Pecíolo visível dorsalmente; T1 liso, com pouca pilosidade látero-dorsal, margem posterior reta; T2-T5 lisos, com pouca pilosidade látero-dorsal e margem posterior ligeiramente côncava; T6-T7 lisos, com pouca pilosidade láterodorsal, margem posterior convexa; hipopígio reto. Ápice acuminado. Medidas relativas: gáster C:L 44:25 (+ ovipositor 3); T1 C 26; T7+T8 5:6.

Etimologia. Epíteto específico em referência a metatíbia com ápice alargado.

\section{Distribuição. Brasil (AM)}

Hospedeiros. Desconhecidos.

Comentários. Esta espécie assemelha-se a $C$. diminuta $\mathbf{s p . ~}$ nov. na coloração, cabeça globosa, escutelo plano com área central sem umbílicos e interstício coiáceo (Fig. 68), mas pode ser diferenciada desta e das demais espécies do grupo através da metatíbia alargada e comprimida lateralmente no ápice (Fig. 69), metafêmur com parte basal mais estreita que a distal (Fig. 69) e gáster com tergitos lisos.

Material examinado. Holótipo fêmea, com a etiqueta 'BRA[SIL] AM[AZONAS] - Manaus Reserva R. Ducke 06 a 17.VII.1992 Arm[adilha] Adesiva 1B 10m Vidal \& Vidal, col.' (INPA).

\section{Ceyxia ventrispinosa Girault, 1911 stat. rev.} (Figs. 40-42)

Ceyxia ventrispinosa Girault, 1911: 383, 383-386 [Paraguai: Villa Morra].

Brachymeria (Brachymeria) ventrispinosa: De Santis 1979a: 8, 63. Brachymeria flaviscapus: Bouček 1992: 89 (como sinônimo sênior de C. vesntrispinosa).

Diagnose. Carena da margem do escrobo se estende sobre a área parescrobal; projeção interantenal com tubérculo apical; margem superior do escrobo distando do ocelo anterior $0,25 \mathrm{x}$ o DOA; porção superior da lateral do pronoto com uma ou mais rugas transversais acima do sulco transversal (Fig. 41); carena frenal não muito alongada, com a margem ligeiramente côncava (Fig. 40); dobra cubital glabra; metafêmur com os dentes inferiores pequenos e aproximadamente do mesmo tamanho (Fig. 42); metatíbia com distinto espinho apical; e escapo amarelo.

Descrição. Fêmea. Comprimento 3,7-5,7 mm.

Coloração. Negra, exceto: olho e ocelos castanhos; escapo, tégula, pernas anterior e média, face ventral da metacoxa, margem superior da face externa do metafêmur, metatíbia e tarsos amarelos. Asas hialinas. Pilosidade do tronco branca.

Cabeça. Pilosidade 2x mais longa que o diâmetro dos umbílicos, mais esparsa na área ao redor dos ocelos. Umbílicos da fronte e porção anterior do vértice com $0,3 \mathrm{x}$ do DOA, na porção posterior do vértice umbílicos inconspícuos; interstício coriáceo, com cerca de $0,5 \mathrm{x}$ o diâmetro dos umbílicos. Face inferior com densa pontuação pilosa rasa, interstício liso. Vértice com perfil arredondado. Face com perfil ligeiramente convexo. Ocelo anterior situado fora do escrobo; este com margem carenada até $0,6 \mathrm{x}$ de sua altura, de onde a carena se estende por sobre o espaço parescrobal (como na Fig. 8); superfície interna lisa, inconspicuamente esculturada no topo. Projeção interantenal muito desenvolvida, normalmente com tubérculo apical. Mandíbulas com dente superior muito reduzido e afastado do ápice (como na Fig. 26). Carena pósorbital encontra a carena genal no nível da margem inferior dos olhos. Carena occipital inconspícua próximo ao forâmen occipital (como na Fig. 44). Antenas estreitadas no ápice; escapo não atingindo a margem do ocelo anterior; F1 obcônico. Medidas relativas: cabeça C:A:L 24:32:54; FV 22; LS 17; EPE 6; ETC 6; EM 6; FO 20; DOA 6; APL 4; OOL 3; POL 9; olho A:L:LF 31:23:15; escapo antenal C:L 15:5; pedicelo 2:3; anellus C 1; F1 5:6, F2-F4 5:7; F5 4,5:7; F6-F7 4:6; clava 9:5.

Mesossoma. Dorso convexo, pilosidade cerca de 2x mais longa que o diâmetro dos umbílicos, no escutelo mais que $2 \mathrm{x}$ esse diâmetro. Umbílicos do pronoto, margem anterior do lobo mediano do mesoscuto e escápula com 0,4 x o DOA; no restante do lobo mediano e escutelo cerca de $0,5 \mathrm{x}$ o DOA; interstício coriáceo, menor que $0,5 \mathrm{x}$ o diâmetro dos umbílicos, nas escápulas atingindo o diâmetro dos umbílicos. Carena pronotal ausente na porção mediano-dorsal por $0,75 x$ do FV. Umbílicos da margem posterior do pronoto conspícuos, formando uma carena anterior irregular em suas margens anteriores. Porção superior da lateral do pronoto coriácea, com rugas, às vezes inconspícuas, delimitando a margem dorsal do sulco transversal (Fig. 41); este, normalmente interrompido por carenas curtas. Escutelo convexo; carena frenal bem desenvolvida, margem côncava (Fig. 40). Área frenal com duas a três carenas transversais conspícuas, interstício inconspicuamente esculturado. Mesepisterno com interstício liso. Carena epicnemial bilobada na porção ventral. Área subalar inconspicuamente coriácea. Depressão femoral com algumas carenas transversais curtas e inconspícuas acima da transepimeral, quase toda lisa. Epímero superior liso. Aréola 

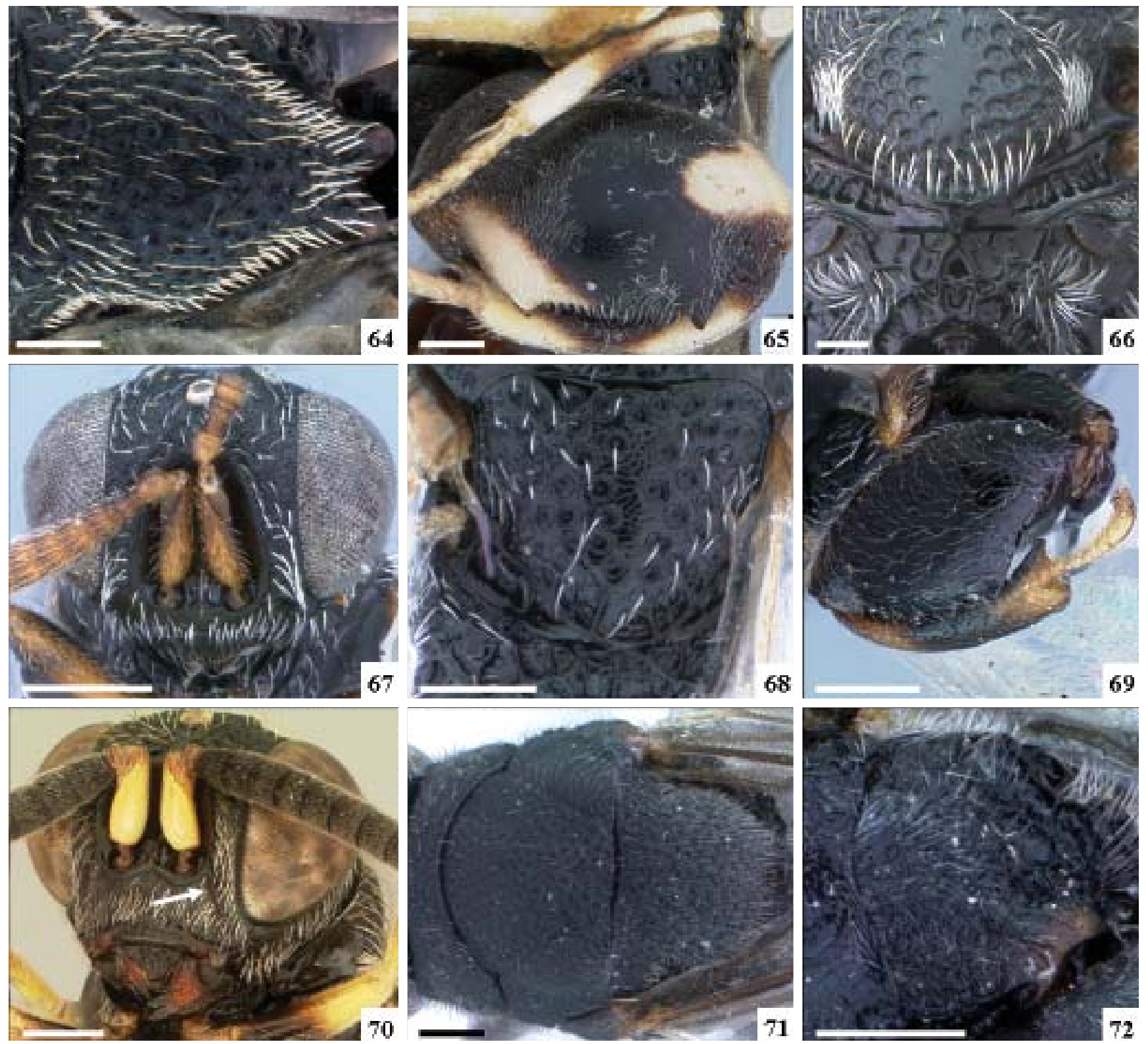

Figs. 64-72. 64-65. Ceyxia longiscutellaris sp. nov., fêmea: 64, escutelo dorsal; 65, metafêmur e metatíbia. 66. Ceyxia paraensis. sp. nov., fêmea, escutelo e propódeo dorsal. 67-69. Ceyxia tibiodilatata sp. nov., fêmea: 67, cabeça frontal; 68, escutelo dorsal; 69, metafêmur e metatíbia. 70. Ceyxia decreta comb. nov., fêmea, cabeça diagonal, indicando carena escrobo-malar. 71-72. Caenobrachymeria sp, fêmea: 71, mesossoma dorsal; 72, metapleura. Escala $400 \mu \mathrm{m}$.

mediana pentagonal do propódeo cerca de 2,5x mais longa que larga. Asa anterior com a dobra basal com duas a três fileiras de cerdas; dobra cubital glabra; linha de cerdas subcubital presente abaixo da dobra cubital; célula basal glabra. Metafêmur (Fig. 42) ligeiramente ovalado, com oito a dez dentes pequenos na margem inferior, o basal mais agudo, pilosidade pouco mais curta que $2 \mathrm{x}$ a distância entre os pontos. Espinho apical da metatíbia agudo e com o ápice reto. Medidas relativas: mesossoma C:L 66:50; pronoto C 13; mesoscuto C 27; escutelo C:L 27:28; asa C:L 110:45, SM 45, M 26, PM 7, ES 2; metacoxa C 26; metafêmur C:L 43:24.
Metassoma. Pecíolo indistinto dorsalmente. T1 cerca de 0,6x o comprimento do gáster; inconspicuamente coriáceo, quase liso, com pontuação pilosa látero-dorsal e pontuado ao longo da margem posterior das laterais; margem posteriordorsal reta. T2-5 com margem posterior ligeiramente côncava, coriáceos, com densa pontuação pilosa nas laterais. T6 com umbílicos conspícuos. Hipopígio com o ápice emarginado medianamente, no fundo da emarginação com pequena projeção. Ápice acuminado. Medidas relativas: gáster C 75 (+ 2 ovip.); T1 C 35; T7+8 5:4. 
Macho. Comprimento: 3,8-5,0 mm.

Semelhante à fêmea, exceto por apresentar ápice do gáster não acuminado e pilosidade sensorial na face ventral dos flagelos, mais longa e conspícua nos F2-F4.

Distribuição. Brasil (SE, MT, GO, DF, MS, MG, SP), Bolívia*, Paraguai e Argentina.

Hospedeiros. desconhecidos.

Comentários. Bouček (1992) considerou C. ventrispinosa como sinônimo júnior de $C$. flaviscapus, porém, aqui estes são considerados como estes pertencem à espécies distintas. As diferenças mais marcantes dessa espécie são: carena da margem do escrobo que se estende sobre a área parescrobal; carena frenal não muito alongada, com a margem ligeiramente côncava (Fig. 40); porção superior da lateral do pronoto com uma ou mais rugas transversais acima do sulco transversal (Fig. 41); dobra cubital glabra; metafêmur com os dentes inferiores pequenos e aproximadamente do mesmo tamanho (Fig. 42); e metatíbia com distinto espinho apical. O holótipo de $C$. ventrispinosa encontra-se sem cabeça, mas apesar dos caracteres da cabeça serem diagnósticos para a espécie, é possível diferenciá-la das outras espécies através da coloração do escapo, que não foi perdido; a asas anteriores enegrecidas e aréola abaixo da carena frenal dividida longitudinalmente. A espécie é semelhante a $C$. dentiformis sp. nov. e $C$. atuberculata $\mathbf{s p . ~ n o v . , ~ m a s ~ s e ~ d i f e r e n c i a , ~ a l e ́ m ~ d o s ~ c a r a c t e r e s ~}$ acima, através da projeção interantenal com tubérculo apical e distância entre a margem superior do escrobo e ocelo anterior $0,25 x$ o DOA.

Material examinado. Holótipo: macho (parcialmente destruído: sem cabeça, perna anterior esquerda, tarsos anteriores direitos, perna posterior direita), com as etiquetas 'Paraguay, S. Amer, Villa Morra, 23.xii.05, JDAnisits', '31936', 'Ceyxia ventrispinosa Girault macho', 'ex coll Girault', 'Type', 'Zool. Mus. Berlin' 'Holotypus macho, Ceyxia ventrispinosa Girault, 1911/Bouček, 1971' (ZMHB). Material nãotipo: BRASIL, Sergipe: 1 fêmea, Canindé, São Francisco-Xingó, caatinga, 28-01.I.2003 (UFES). Mato Grosso: 1 fêmea, Rondonópolis, Área Indígena Tadarinama, 24.X.1991, varredura de vegetação (M. T. Tavares) (UFES). Goiás: 1 fêmea, Itumbiara, Fazenda da Faculdade de Agronomia, 29.V.2002, arm. Malaise (C. H. Marchiori \& eq.) (UFES); Distrito Federal: 3 fêmeas, Brasília, Reserva Ecológica do IBGE, 20.V.1985 (J. Dalmacio) (IBGE); 1 fêmea, ibidem, 10-17.II.1983 (IBGE). Mato Grosso do Sul: 1 macho, Corumbá, lowland, III (H.H.Smith) (USNM); 1 fêmea, Corumbá, Passo do Lontra, 812.XI.1993, arm. Suspensa (L.Joaquim \&L. Reis) (DCBU); Minas Gerais: 3 fêmeas, Belo Horizonte, Estação Ecológica da UFMG, 24.XI01.XII.1996, arm Malaise (J. C. R Fontenelle) (UFMG); 1 fêmea, Belo Horizonte, Prefeitura Campus UFMG, 07.VI.1996 (J. C. R Fontenelle) (UFMG); São Paulo: 1 fêmea, São Paulo, Ypiranga \# 18830 (MZSP); 1 fêmea, São Paulo, VI.1938 (Schurchel) (IBSP). BOLIVIA, Santa Cruz: 8 fêmeas, Roboré, X.1959 (SEMC). ARGENTINA, 1 fêmea, Porto Iguaçu, 18.III.1945 (W. Golback) (IMLA).

\section{Ceyxia villosa (Olivier, 1790) comb. nov.} (Figs. 43-45)

Chalcis villosa Olivier 1790: 438 [TRINDAD e TOBAGO: Vale Caura]. Dalla Torre 1898: 393; Ashmead 1904: 411; Schmiedeknecht 1909: 29.
Chalcis augurus Walker 1841: 134 [BRASIL]. Dalla Torre 1898: 386; Ashmead 1904: 409; Schmiedeknecht 1909: 26; Bouček 1992: 94 (desig. de sin.).

Chalcis pubescens Walker 1871: 4-8 [MÉXICO] non C. pubescens Klug 1834. Cresson 1872: 59; Cameron 1884: 99; Bouček 1992: 94 (desig. de sin.).

Chalcis mexicana Dalla Torre 1898: 389 (desig. de novo nome para $C$. pubescens Walker, non Klug). Schmiedeknecht 1909: 27; Bouček 1992: 94 (desig. de sin.).

Brachymeria mexicana (Dalla Torre): Rau 1940: 594; 1941: 365.

Brachymeria (Brachymeria) mexicana (Dalla Torre): Burks 1960: 240; De Santis 1979a: 59; 1979b: 2; 1981: 4; 1989: 13; Fritz \& Genise 1980: 71.

Brachymeria (Brachymeria) villosa (Olivier): De Santis 1979a: 63.

Brachymeria augurus (Walker): De Santis 1980: 251.

Brachymeria villosa (Olivier): Bouček 1992: 94; Arias \& Delvare 2003 : 130; Peruquetti 2001: 695-697.

Variações. Em alguns exemplares o tamanho dos umbílicos do mesossoma varia, conseqüentemente, a pilosidade pode ser mais densa ou mais esparsa, assim como a pilosidade do gáster. Em alguns exemplares, como nos do Peru, a pilosidade do dorso do mesossoma é esbranquiçada e mais esparsa. O metafêmur pode apresentar mancha amarela em toda extensão da margem superior ou ser completamente negro. A carena frenal pode ser menos desenvolvida.

Distribuição. México, Guatemala*, Honduras*, Nicaragua*, Costa Rica*, Panamá, Trinidad \& Tobago, Colombia, Venezuela, Brasil (AM*, PA*, MG, SP*, RJ, PR*, SC), Paraguay, Argentina.

Hospedeiros. Bouček (1992) citou exemplares criados de Trypoxylon albitarse (Fab.) (Crabronidae, Larrinae) em Trinidad e Burks (1960) de T. mexicanum Richards. Essas associações são reforçadas pelas informações dos exemplares examinados (ver abaixo). Peruquetti (2001) descreve o comportamento de oviposição e tempo de desenvolvimento da espécie sobre $T$. albitarse.

Comentários. Esta espécie é identificada através da pilosidade densa e dourada no dorso da cabeça e mesossoma; cabeça 2,8x mais larga que longa; mandíbula alongada e unidentada (Fig. 43); projeção interantenal formada por uma lâmina espessa (Fig. 43); carena frenal alongada e côncava (como na Fig. 11), dentes da margem inferior do metafêmur bem desenvolvidos, sendo o basal o maior (Fig. 45).

Material examinado. Neótipo: fêmea, com as seguintes etiquetas 'Trindad (W.I.), Caura Valey, III.80 B.Freemann', 'Brachymeria villosa (Olivier) Bouček, 1980', 'Neotipo/ Bouček, 1991', 'Neotype, Br. villosa (Olivier 90), Det. Z. Bouček, 1991', 'B.M.Type hym. 5-3523' (BMHN). Material não-tipo. MÉXICO, Oaxaca: 1 fêmea, Temascal, 23.X.1963 (K. H. Janzen) (EMEC); Yucatan: 1 fêmea, Xuchmal, 20.X.1983 (M. A. Montague) (UCDC). GUATEMALA, Suchitepéquez: 2 machos, 6 fêmeas, Guatalón, Mocá, 1000 m, II-IV.1931 (J. Bequert) (MCZH); Chimaltenango: 1 fêmea, Pochuta, Santa. Emilia, 1000 m, II-III.1931 (J. Bequert) (MCZH). HONDURAS, Atlantida: 1 fêmea, Lancetilla, VIII (Standermann) (MCZH); 2 espécimes, 24.IV.1936, emergido de pupa de Trypoxylon mexicanum sobre caule de banana (E. P. Reed) (CAS). NICARÁGUA, Manágua: 1 fêmea, Manágua, 10.XII.1950 (Swain) (AMNH). COSTA RICA, Cartago: 1 fêmea, Turrialba, 600 m, 24-26.VI.1974 (W. A. Harding \& J. P. Donahue) (LACM); Guanacaste: 1 fêmea, La Pacifica, 4 km NW Canas, 
23.V.1973 (Opler) (EMEC); 1 fêmea, Liberia, 09.VIII.1964 (C. L. Hogue) (LACM); 1 fêmea, Praia Junquillal, 08.III.1976 (R. M. Bohart) (EMEC); Puntarenas: 5 fêmeas, Palmar (P \& D. Allen) (MCZH); 1 fêmea, ibidem, V.1949 (MCZH). PANAMÁ, Zona do Canal: 1 fêmea, Cano Saddle, VI.1923 (M. F. Close) (USNM); 1 fêmea, Fort. Clayton, 08.VIII.1945 (K. E. Frick) (CAS). COLÔMBIA, Boyaca: 5 fêmeas, Muzo, VI.1936 (J. Bequaert) (MCZH); Valle del Cauca: 1 fêmea, 11 $\mathrm{km}$ ao sul de Cali, 10.III.1969 (B. Malkins) (AMNH). VENEZUELA, Aragua: 1 fêmea, Pto. de Cata, 19.IX.1973 (B. Villegas) (UCDC); 1 fêmea, E. Dorest, Cagua, 27.X.1968 (EMEC). EQUADOR, Napo: 1 fêmea, Coca, XI.1987 (G. Onore) (QCAZ); 1 fêmea, Tarapoa, VI.1984 (J. Yépez) (QCAZ). PERÚ, Ucayali: 1 fêmea, Médio Rio Ucayali, 27.X.1923 (H. Bassler) (AMNH); Huánuco: 1 fêmea, Tingo Maria, Vale Monson, 21.XI.1954 (E. I. Schlinger \& E. S. Ross) (CAS); 2 fêmeas, ibidem, 1.I.1955, emergidos de casulos de Sceliphron (CAS); 1 macho, 4 fêmeas, ibidem, 23.XII.1954 e 11.XII.1954, emergidos de casulos de Trypoxylon sp (CAS); Pasco: 1 fêmea, Pan Azucar, 25.VI.1961 (F. S. Truzal) (LACM). BRASIL, Amazonas: 1 fêmea, Manaus, Reserva Ducke, 17.XI.1988, armadilha suspensa 10 metros (J. A. Rafael) (INPA); Pará: 1 fêmea, km 90 rodovia Belém-Brasília, Fazenda Santo Antônio, 28.VII.1972 (M. Helena) (MPEG); Minas Gerais: 3 fêmeas, Viçosa, 30.II.1998, emergido de Trypoxylon albitarse (S. M. R. Araújo) (UFES); Rio de Janeiro: 1 fêmea (O. Mendes) (MNRJ); 3 fêmeas, Guaratiba, 3.IV.1932, 12.XII.1933 e 14.IV.1942 (A. Silva) (UFRRJ); São Paulo: 1 fêmea, Santos, Praia do Itaguaré, 29.VIII.1961 (Rabello) (MZSP); 1 macho, São Paulo, cidade universitária, 27.XII.1988, emergido de casulo de Trypoxylon albitarsi (S. Amarante) (MZSP); 1 fêmea, Cajuru, Faz. Santa Carlota, 27.VIII-3.IX.1995 (Camilo e Serrano) (DZUP); Parana: 2 fêmeas, Paranaguá, III.1937 (G. Farchild) (MCZH); Santa Catarina: 1 fêmea, Cauna, XII.1945 (A. Maller) (AMNH); 1 fêmea, Nova Teotônia, 29.IV.1948 (F. Plaumann) (AMNH); 1 fêmea, ibidem; 05.I.1965 (LACM). ARGENTINA, Entre Rios: 2 fêmeas, Chajari, I.1979 (Fritz) (IIES).

Agradecimentos. A todos os curadores ou responsáveis pelas coleções entomológicas listadas acima; ao Dr. Celso Oliveira Azevedo (Universidade Federal do Espírito Santo), Dr. Nelson Wanderley Perioto (Apta Regional Centro-Leste, Ribeirão Preto, São Paulo) e aos dois revisores anônimos pelas sugestões e correções apontadas; ao Bruno Cancian de Araújo (Universidade Federal do Espírito Santo) pelo apoio na confecção da chave de identificação; à Maria Tereza Picinoto Maglia e ao José Augusto Maulin (Laboratório de Microscopia Eletrônica, Departamento de Medicina, Faculdade de Medicina de Ribeirão Preto, Universidade de São Paulo) pelo apoio na confecção das micrografias eletrônicas de varredura; à Carla Zandonadi Souza (Universidade Federal do Espírito Santo) pela confecção das fotomicrografias em foco estendido. O segundo autor (M.T.T.) agradece: à Smithsonian Institution pelo suporte financeiro para visita ao National Museum of Natural History (Washington); e ao Dr. Eduard Eric Grissell (Smith. Inst., Washington) pelo apoio na concretização daquela visita. Este estudo teve o apoio parcial do CNPq (procs. $\mathrm{n}^{\circ}$ 620064/2006-4, $\mathrm{n}^{\circ}$ 482629/ 2007-0), FAPES (proc. $n^{\circ} 41959329 / 08$ ), FAPESP (proc. $n^{\circ}$ 98/05083$0)$ e PROTAX (CNPq/CAPES/MCT, Proc. n563953/2005-5).

\section{REFERÊNCIAS}

Arias, D. C. \& G. Delvare. 2003. Lista de los géneros y especies de la família Chalcididae (Hymenoptera: Chalcidoidea) de la región Neotropical. Biota Colombiana 4: 123-145.

Ashmead, W. H. 1904. Classification of the Chalcid-flies of the superfamily Chalcidoidea with descripitions of new species in the Carnegie Museum, collected in South American by Herbet H. Smith. Memoirs of the Carnegie Museum 1: 225-255.

Bouček, Z. 1988. Australasian Chalcidoidea (Hymenoptera): a biosystematic revision of genera of fourteen families, with a reclassification of species. Wallingford, C.A.B. International. $832 \mathrm{p}$.

Bouček, Z. 1992. The New World genera of Chalcididae. Memoirs of American Entomological Institute 53: 49-118.
Burks, B. D. 1936. The Ilinois species of Brachymeria (Hymenoptera, Chalcididae). Transactions of the Illinois State Academy of Science 29: 251-254.

Burks, B. D. 1960. A revision of the genus Brachymeria Westwood in America north of Mexico (Hymenoptera: Chalcididae). Transactions of the American Entomological Society 86: 225273.

Burks, B. D. 1979. Chalcididae. p. 860-874. In: K. V. Krombein, P. D. Hurd Jr., D. R. Smith, B. D. Burks (Eds.). Catalog of Hymenoptera in America north of Mexico. Symphyta and Apocrita (Parasitica) 1: p. 860-874. Washington D.C., Smithsonian Institution Press, xvi+1198 p.

Cameron, P. 1884. Chalcididae. p. 81-96+pls. 4-6. In: F. D. Goodman \& D. Salvin (Eds.). Biologia Centrali-Americana. Insecta. Hymenoptera (Families Tenthredinidae-Chrysididae). 1. London, Taylor and Francis, xii+487 p., 20 pranchas.

Crawford, J. C. 1910a. New parasitic Hymenoptera. Proceedings of the Entomological Society of Washington 11: 203-207.

Crawford, J. C. 1910b. Tical results from the gipsy moth parasite laboratory. II, Descriptions of certain chalcidoid parasites. U. S. Department of Agriculture, Bureau of Entomology, Technical Series 19: 13-24.

Cresson, E. T. 1872. Synopsis of the North American species belonging to the genera Leucospis, Smicra and Chalcis. Transactions of the American Entomological Society 4: 29-60.

Dalla Torre, C. G. 1898. Catalogus Hymenopterorum hucusque descriptorum systematicus et synonymicus. V. Chalcididae et. Proctotrupidae. Lipszig, S.G.Engelmann, 589 p.

Delvare, G. 1992. A reclassification of the Chalcidini with a check list of the New World species. Memoirs of the American Entomological Institute 53: 119-442.

De Santis, L. 1979a. Catalogo de los Himenópteros Calcidoideos de América al sur de los Estados Unidos. La Plata, Comisión de Investigación Científica, 488 p.

De Santis, L. 1979b. Nuevas citas de Himenopteros Calcidoideos para la Republica Argentina (Insecta). Neotropica 24: 2.

De Santis, L. 1980. Catalogo de los Himenópteros Brasileños de la serie parasitica: incluyendo Bethyloidea. Curitiba, Universidade Federal do Paraná, 395 p.

De Santis, L. 1981. Catalogo de los Himenopteros Calcidoideos de America al Sul de los Estados Unidos, Primer suplemento. Revista Peruana de Entomologia 24: 1-38.

De Santis, L. 1989. Catalogo de los Himenopteros Calcidoideos de America al Sul de los Estados Unidos, Segundo suplemento. Acta Entomologica Chilena 15: 9-90.

Evenhuis, N. L. 2009. Abbreviations for Insect and Spider Collections of the World. Disponível em: <http:// hbs.bishopmuseum.org/codens/codens-inst.html>. Acesso em 25 fevereiro 2009.

Fritz, M. A. \& J. A. Genise. 1980. Notas sobre nido de barro de Sphecidae (Hymenoptera) constructores, inquilinos, parasitoides, cleptoparasitos y detritivoros. Revista de la Sociedad Entomologica Argentina 39: 67-81.

Gibson, G. A. P. 1997. Morphology and terminology, p. 16-44. In: G. A. P. Gibson, J. T. Huber, J. B. Woolley (ed). Annoted keys to the genera of Neartic Chalcidoidea (Hymenoptera). Ottawa, NCR Research Press, xi+794 p.

Girault, A. A. 1911. New Chalcidoidea genera and species from Paraguay. Zoologische Jahrbücher, Abteilung für Systematik 31: 377 406.

Girault, A. A. 1913. New genera and species of chalcidoid Hymenoptera from Paraguay. Archiv für Naturgeschichte 79: 51-69.

Harris, R. A. 1979. A glossary of surface sculpturing. Occasional Papers in Entomology 28: 1-31.

Kirby, W. F. 1883. Remarks on the genera of the subfamily Chalcidinae, with synonymic notes and descriptions of new species of Leucospidinae and Chalcidinae. Journal of the Linnean Society of London, Zoology 17: 53-78.

Olivier, M. 1790. Histoire Naturelle. Insectes. Encyclopedie Methodique 5: 435-440. 
Peruquetti, R. C. 2001. Comportamento de oviposição e tempo de desenvolvimento de Brachymeria villosa (Olivier) (Hymenoptera, Chalcididae). Revita Brasileira de Zoologia 18: 695-697.

Peruquetti, R. C. \& M. A. Del-Lama. 2003. Notas sobre a socialidade e a biologia de nidificacao de Trypoxylon (Trypoxylon) asuncicola Strand, 1910 (Hymenoptera, Sphecidae). Revista Brasileira de Entomologia 47: 297-301

Portuondo-F., E. 2005. El genero Brachymeria Westwood (Hymenoptera, Chalcididae) en Cuba. Boletin de la Sociedad Entomológica Aragonesa 37: 237-243

Peck, O. 1951. Superfamily Chalcidoidea. p. 410-594. In: C. F. W. Muesebeck, K. V. Krombein, H. K. Townes (Eds.). Hymenoptera of America north of Mexico. Agriculture Monographs, U.S. Department of Agriculture 2: $1420 \mathrm{p}$.

Rau, P. 1940. The nesting habits of several species of Mexican social wasps. Annals Entomological Society of America 33: 81-92.

Schmiedeknecht, O. 1909. Genera insectorum. 97, Hymenoptera fam. Chalcididae. Brussels, M. P. Wytsman, 550 p.
Walker, F. 1841. Descriptions of Chalcidites (continued). The Entomologist 1: 217-220.

Walker, F. 1861. Characters of undescribed species of the family Chalcidae. Journal of Entomology 1: 172-185.

Walker, F. 1862. Notes on Chalcites, and characters of undescribed species. Transactions of the Entomological Society of London (s. 3) 1: 345-397.

Walker, F. 1864. Characters of undescribed species of Smiera (Chalcidites). Transactions of the Entomological Society of London (s. 3) 2: 181-207.

Walker, F. 1871. Torymidae and Chalcididae. Notes on Chalcidiae 3 39-54.

Wijesekara, G. A. W. 1997. Phylogeny of Chalcididae (Insecta: Hymenoptera) and its congruence with contemporary hierarchical classification. Contributions of the American Entomological Institute 29: 1-61. 